\title{
Rácsséták bijektív leszámlálása
}

\author{
Doktori értekezés
}

NAGY GÁBOR

Témavezetô:

Dr. Hajnal PÉter

Matematika- és Számítástudományok Doktori Iskola Szegedi Tudományegyetem

Természettudományi és Informatikai Kar

Bolyai Intézet

Szeged

2014 


\section{Tartalomjegyzék}

1. Bevezetés 3

1.1. A bijektív kombinatorika 3

1.2. A dolgozat felépítése és tartalma 4

2. Páros indexú Catalan-számok konvolúciója 6

2.1. Shapiro konvolúciós formulája 6

2.2. A kombinatorikus bizonyítás $\quad 7$

2.3. A bijektív bizonyítás 16

2.4. Alkalmazások 31

2.5. További problémák 38

3. Diszkrét véletlen séták egy konvexitási tulajdonsága 41

3.1. Bevezetés 41

3.2. A diszkrét konvexitási lemma elemi bizonyítása 43

3.3. Magasabbról indított véletlen séták 48

3.4. Analóg eredmények magasabb dimenziókban 55

Összefoglalás $\quad 58$

$\begin{array}{ll}\text { Summary } & 61\end{array}$

Köszönetnyilvánítás $\quad 64$

Jelölések, fogalmak $\quad 65$

$\begin{array}{ll}\text { Irodalomjegyzék } & 66\end{array}$ 


\subsection{A bijektív kombinatorika}

Ebben a dolgozatban a klasszikus értelemben vett kombinatorika, az összeszámlálási kombinatorika területéhez tartozó problémákat vizsgálunk. A tekintett problémák megoldásához tehát véges halmazok elemszámának pontos meghatározására, illetve esetünkben ezen számosságok összehasonlítására lesz szükség. (Elsôsorban kombinatorikus azonosságokkal és egyenlótlenségekkel foglalkozunk majd.) A legelemibb munkamódszert választjuk; két halmaz elemszámának egyenlőségét mindig bijekció megadásával igazoljuk. Az összeszámlálási kombinatorika ezzel a módszerrel dolgozó alága a bijektív kombinatorika, mely a kombinatorikus alapmennyiségekhez (például a binomiális együtthatókhoz, vagy a Catalan-számokhoz) egy-egy „reprezentáló” halmazt társít, és az alapmennyiségekre kizárólag ezen halmazok elemszámaként tekint, így a konkrét számértékeken végzett algebrai manipulációk helyett csakis e halmazok segítségével érvel. (Például ha egy összeszámlálási problémára az $\left(\begin{array}{l}n \\ k\end{array}\right)$ binomiális együttható a válasz, akkor ahelyett, hogy egy könnyen felírható alakból kiindulva algebrai átalakításokkal „kiszámoljuk”, hogy a válasz $\frac{n !}{k !(n-k) !}$, célunk bijekciót megadni a megszámolandó objektumok halmaza és az $\{1, \ldots, n\}$ halmaz $k$ elemú részhalmazainak halmaza között.) A keresett bijekcióval szemben hallgatólagos elvárás, hogy egyszerúen legyen definiálva (azaz az elemek képét meg lehessen kapni egy hatékony determinisztikus algoritmussal), és a leképezés bijekció volta könnyen ellenôrizhetô legyen. Bár kétségtelen, hogy esztétikai szempontok is szerepet játszanak, természetesen ez a célkitúzés nem öncélú: Egyrészt nehezen vitatható, hogy ez a legletisztultabb, legszemléletesebb módja a kombinatorikus érvelésnek, míg az algebrai manipulációk - a többi, mélyebb technikával együtt - bizonyos szempontból inkább elfedik a „lényeget”, akkor is, amikor esetleg ezt az utat érezzük egyszerúbbnek „mechanikussága” miatt. Másrészt, a modernebb módszerek mellett továbbra is van létjogosultsága az elemi megközelítésnek, hiszen sokszor gyorsabban célt érhetünk elemi eszközök felhasználásával (esetleg más módszereket kiegészítve), mint nélkülük. Erre, és az ellenkezőjére is látunk majd példát a késóbbi fejezetekben. Megfigyelhetô tendencia ugyanakkor, hogy a nehezebb összeszámlálási problémákra általában elóbb születnek nem kombinatorikus bizonyítások, mint bijektívek. Ez abból is fakad, hogy a modernebb módszerek jellemzően univerzálisabbak, míg egy alkalmas bijekció (bijektív bizonyítás) megkonstruálására nincs bevált „recept”, pusztán korábban látott trükkök, hasonló problémák, esetleg más módszerekkel kiszámolt tények jelenthetnek segítséget. (Léteznek ugyan olyan eljárások, melyekkel bizonyos nem bijektív módszerek bijektivizálhatók, de így általában kombinatorikus indoklásként nehezen elfogad- 
ható, bonyolult bijekciókat kapunk. A partíciós azonosságok vizsgálatában lényeges előrelépés történt ebből a szempontból, melyre a következő bekezdésben még visszatérünk.) Az összeszámlálási kombinatorika egy átfogó összefoglalójaként - a bijektív és egyéb módszerek tekintetében is - Stanley kétkötetes Enumerative Combinatorics könyvét ajánljuk $[31,32]$.

A bijektív kombinatorika fontos megoldatlan problémáit sok esetben a más módszerekkel igazolt eredmények szolgáltatják; talán a leghíresebb ezek közül a két Rogers-Ramanujan-azonosság [24,22], melyek Schur és MacMahon észrevétele szerint ekvivalens alakban megfogalmazhatók egyszerúnek látszó és tetszetôs, egész számok partícióira vonatkozó kombinatorikus összefüggésekként is, azonban „szép” bijektív bizonyítást máig nem sikerült találni rájuk. (Garsia és Milne [9] bijektív bizonyítása meglehetősen összetett, de az általuk kidolgozott „involúciós elv" [8] és annak továbbfejlesztése segítségével partíciós azonosságok egész sorát lehet bijektíven bizonyítani, számítógépes segédlettel. Ez az elv jelentős változást hozott a partíciók vizsgálatában, de elfogadottsága nem egységes. A témáról Wilf [34] és Pak [20] munkáiban olvashatunk bóvebben, pro és kontra véleményekkel együtt.)

\subsection{A dolgozat felépítése és tartalma}

Az értekezésben két különböző témakört vizsgálunk a bijektív kombinatorika keretein belül, melyek kapcsolódási pontja a rácsséták megjelenése és felhasználása. (Informálisan, egy $d$-dimenziós rácsséta a $\mathbb{Z}^{d}$ diszkrét tér pontjain sétál, egy pontból mindig annak valamelyik szomszédjára, azaz valamelyik hozzá legközelebb esó pontra lépve.)

A 2. fejezet a [16] és [12] publikációkat dolgozza fel. Ebben a részben a Stanley által is népszerüsített $[29,30]$

$$
\sum_{k=0}^{n} C_{2 k} C_{2 n-2 k}=4^{n} C_{n}
$$

konvolúciós azonossággal foglalkozunk, ahol $C_{n}$ az $n$-edik Catalan-számot jelöli. (A Catalan-számok a kombinatorika alapvetô mennyiségei, melyekról bőséges ismeretanyagot tartalmaz Stanley [32] könyve és Koshy [13] monográfiája.) A fenti tetszetôs formula Shapiro 2002-es eredménye [13; 123. o.], melyet nem nehéz formális hatványsorokkal igazolni, Shapiro is így érvelt. Megjegyezzük, hogy komputeralgebrai rendszerekkel is dolgozhatunk: A hipergeometrikus azonosságok számítógépes ellenőrzésére is használható Zeilberger-algoritmus tömör, matematikailag korrekt bizonyítást talál. (Az algoritmus részletes leírása megtalálható a [21] könyvben.) Bár ezekkel a módszerekkel egy-egy kompakt indokláshoz jutunk, az azonosság kombinatorikus jelentése rejtve marad. Tekintve, hogy egy kombinatorikus alapmennyiségeket tartalmazó, nagyon egyszerú formuláról van szó, természetesen fogalmazódik meg a kombinatorikus bizonyítás igénye. (Kombinatorikus bizonyítás alatt azt értjük, hogy felmutatunk egy olyan összeszámlálási problémát, amelyet a bal és jobb oldal egyaránt megválaszol, így a két oldal szükségképpen egyenlő.) 
Rövid történeti áttekintés után a 2. fejezetben ismertetünk egy egyszerú kombinatorikus, majd pedig egy arra épülő teljesen bijektív bizonyítást, ezzel megoldjuk a Stanley által kitüzött feladatot [29; 194. probléma]. Bizonyításaink speciális utak kettős leszámlálásán alapulnak. Ezután áttekintjük módszerünk néhány következményét, melyek közül a legfontosabb a középsó binomiális együtthatók alternáló konvolúciós formulájának [28] új elemi bizonyítása. A témakör lezárásaként bemutatjuk a Shapiro-azonosság bizonyításában szereplő összeszámlálási probléma általánosítását, és sejtésként fogalmazzuk meg az általunk helyesnek gondolt választ.

A [18] és [17] publikációkon alapuló 3. fejezetben áttérünk egy másik területre; itt diszkrét véletlen sétákkal foglalkozunk, mely témakörhöz Spitzer klasszikus [27] könyvét ajánljuk elméleti kiegészítésként. Az ismertetett problémát az elôzőekkel ellentétben kombinatorikus megfontolások nélkül nehezebb kezelni, mint elemi kombinatorikai eszközök igénybevételével. A probléma Totik Vilmostól származik, aki harmonikus mértékekkel kapcsolatos kutatásai során fogalmazta meg 2012-ben a következő lemmát (és bizonyította elsôként, Fourier-analitikus eszközökkel): Ha $p_{k}$ jelöli annak a valószínúségét, hogy a négyzetrács $(0,1)$ pontjából induló szimmetrikus véletlen séta a $(k, 0)$ pontban lép először az $x$-tengelyre $(k \in \mathbb{Z})$, akkor a $\left(p_{k}\right)_{k=0}^{\infty}$ sorozat konvex. Erre az állításra egy elemi, számolásmentes bizonyítást adunk, melyben a lényegi részt, bizonyos sétahalmazok elemszámára vonatkozó egyenlôtlenséget, a halmazok közötti injektív leképezés megadásával igazoljuk. (Emellett más megoldási módszereket is vázolunk.) Ezután megvizsgáljuk, hogy mit állíthatunk abban az esetben, ha távolabbi kezdôpontból indítjuk a véletlen sétát, majd rávilágítunk módszerünk korlátaira is. Végül eredményeink magasabb dimenziós analogonjait tárgyaljuk.

$\mathrm{Az}$ értekezés végén részletesebben is összefoglaljuk a szakmai fejezetek tartalmát, magyarul és angolul egyaránt.

A könnyebb olvashatóság érdekében törekedtünk arra, hogy minél kevesebb jelölést vezessünk be. A több helyen is használt saját jelöléseinket, illetve a nem egységes szakirodalom alapján többféleképpen is érthető jelöléseket a 65 . oldalon gyújtöttük össze. Ugyanitt megismételtük a dolgozatban szereplő különbözô út- és sétatípusok definícióit egy helyen.

A dolgozat fô tételeit és lemmáit teljes részletességgel bizonyítjuk, további irodalom igénybevételére nincs szükség megértésükhöz. (Néhány fontos hivatkozott eredményt bizonyítással együtt ismertetünk.) Abban az esetben, ha egy korábban már részletezett gondolat megismétlésére lenne szükség, akkor csak vázoljuk, hogy hasonlóan járhatunk el, mint korábban. A fố témánkhoz szorosan nem kapcsolódó állításoknál nem leszünk mindig ilyen alaposak, egyes részek igazolása az olvasóra marad (ezek rutinszerúen elvégezhetôk). A kiegészítő részek kidolgozottsága tükrözi a szerzô matematikai ízlését is. 


\section{Páros indexú Catalan-számok konvolúciója}

\subsection{Shapiro konvolúciós formulája}

A Catalan-számok fontos szerepet töltenek be az összeszámlálási kombinatorikában, hiszen számos probléma megoldása során természetes módon megjelennek: Sloane és Plouffe [26] szerint „,valószínúleg a leggyakrabban előforduló kombinatorikus mennyiségek a binomiális együtthatók után". Szépségükön túl ezért is indokolt minél mélyebb megértésük, melyet sok matematikus tüzött ki célul. A vonatkozó kutatások intenzitását mutatja, hogy Stanley, a bijektív kombinatorika egyik nemzetközileg elismert vezetóje, több mint 200 ekvivalens Catalan-szám definíciót gyûjtött össze alapmúvé vált Enumerative Combinatorics könyvében [32,30]. A következő alfejezetben ezek közül az egyik legstandardabb kombinatorikus értelmezést választjuk majd bizonyításaink kiindulópontjának, most azonban csak a „számszerúsített” definíciót közöljük:

Definíció. Az $\frac{1}{n+1}\left(\begin{array}{c}2 n \\ n\end{array}\right)$ számot az $n$-edik Catalan-számnak nevezzük és $C_{n}$-nel jelöljük. $\diamond$

Közismert, hogy a Catalan-számokra teljesül a következő konvolúciós azonosság (amely a $C_{0}=1$ kezdőértékkel együtt rekurzív definícióként is felfogható):

$$
\sum_{k=0}^{n} C_{k} C_{n-k}=C_{n+1} .
$$

Ez egy egyszerú állítás, amely a bevezetô kombinatorika kurzusok tananyagához tartozik, kombinatorikus bizonyítással együtt. L. Shapiro 2002-ben észrevette, hogy a páros indexú Catalan-számok analóg konvolúciója is elegáns zárt alakra hozható:

2.1. Tétel. (Shapiro $[30 ; 6 . C 18]$ )

$$
\sum_{k=0}^{n} C_{2 k} C_{2 n-2 k}=4^{n} C_{n}
$$

Shapiro formuláját nem nehéz igazolni a Catalan-számok generátorfüggvényének segítségével [13; 123. o.], azonban elsô ránézésre meglepő módon a formula kombinatorikus jelentését jóval nehezebb megfejteni, ez a feladat egy évtizedig megoldatlan maradt. Shapiro nem is publikálta az azonosságot és a [13]-beli egyszerú levezetést; a formula akkor kapott nagyobb publicitást, amikor kombinatorikus módon megoldatlan problémaként bekerült Stanley Bijective Proof Problems on-line 
feladatgyứjteményébe [29; 194. probléma], és a már említett Enumerative Combinatorics könyv Catalan addendum nevet viselő elektronikus kiegészítésébe [30; 6.C18].

Az elsô lényeges előrelépés 2011-ben történt: Andrews ekkor publikálta az azonosság egy $q$-analóg változatát, háromféle bizonyítással [1]. A legmélyebb módszer egy általánosabb azonosságot bizonyít $q$-hipergeometrikus összegzési tételek segítségével, a második gondolatmenet is generátorfüggvényekre támaszkodik, a harmadik megoldás pedig kombinatorikus, amely a szerző megjegyzése szerint „nem nehéz (csak fárasztó) módon bijektív bizonyítássá transzformálható".

2012-ben sikerült elemi kombinatorikai eszközökkel igazolnom Shapiro formuláját [16], továbbá a bizonyítás egyetlen nem bijektív lépését is bijektívvé tettük Hajnal Péterrel 2013-ban [12]. A bizonyítások speciális utak összeszámlálásán alapulnak. Ezek e fejezet fó eredményei, melyeket a 2.2. és 2.3. alfejezetekben részletesen ismertetek. Ezután néhány alkalmazást mutatok be a 2.4. alfejezetben, végül megfogalmazok egy sejtést a 2.5. alfejezetben, amely a bijektív bizonyítás kidolgozása után természetes módon vetődött fel.

Mielőtt rátérnénk a bizonyításokra, megjegyezzük, hogy a (2.1) és (2.2) összefüggések ismeretében könnyen kiszámolható a páratlan indexú Catalan-számok konvolúciója:

$$
\sum_{k=0}^{n-1} C_{2 k+1} C_{2 n-2 k-1}=\sum_{i=0}^{2 n} C_{i} C_{2 n-i}-\sum_{k=0}^{n} C_{2 k} C_{2 n-2 k}=C_{2 n+1}-4^{n} C_{n},
$$

amely tovább nem egyszerúsíthető „algebrailag”, tehát nem várható a fenti érvelésnél egyszerúbb zárt alakra hozás. Ez azt sugallja, hogy Shapiro azonosságának bizonyításához az indexek párosságát fel kell használni.

\subsection{A kombinatorikus bizonyítás}

Bizonyos utak kettős leszámlálásával fogjuk igazolni Shapiro formuláját. Ehhez bevezetjük a páros-metszô utak fogalmát, amiból a páros indexú Catalan-számok olyan nemstandard kombinatorikus értelmezését kapjuk, amely közvetlenül elvezet egy alkalmas összeszámlálási problémához. A nem hivatkozott eredmények a [16] cikkemben kerültek publikálásra.

Formuláinkban többször megjelennek majd $\left(\begin{array}{c}2 n \\ n\end{array}\right)$ alakú binomiális együtthatók a Catalan-számok mellett, így a könnyebb áttekinthetőség érdekében a $B_{n}:=\left(\begin{array}{c}2 n \\ n\end{array}\right)$ jelöléssel élünk, és azt mondjuk, hogy $B_{n}$ az $n$-edik középsó binomiális együttható.

Először definiáljuk az alfejezet alapfogalmait:

Definíció. Egy út felfelé $(\nearrow)$ és lefelé $(\searrow$ ) lépések véges sorozata. Egy út hosszán a lépései számát értjük. A 0 hosszú utat $\varepsilon$-nal jelöljük.

Megjegyzés. Az utakat 2-dimenzióban szemléltetjük a 2.1. ábrán látható módon a standard koordináta-rendszerben. Tehát a definícióban szereplő $\nearrow$ megfelelóje egy $(1,1)$ lépés, a $\searrow$ megfelelóje pedig egy $(1,-1)$ lépés. Használni fogjuk a szemléletes jelentésból eredô fogalmakat (például $x$-tengelymetszet, végpont stb.). A szemléltetéshez az út kezdôpontját tetszólegesen megválaszthatjuk; amennyiben másként nem jelezzük, az utak az origóból indulnak. $\diamond$ 


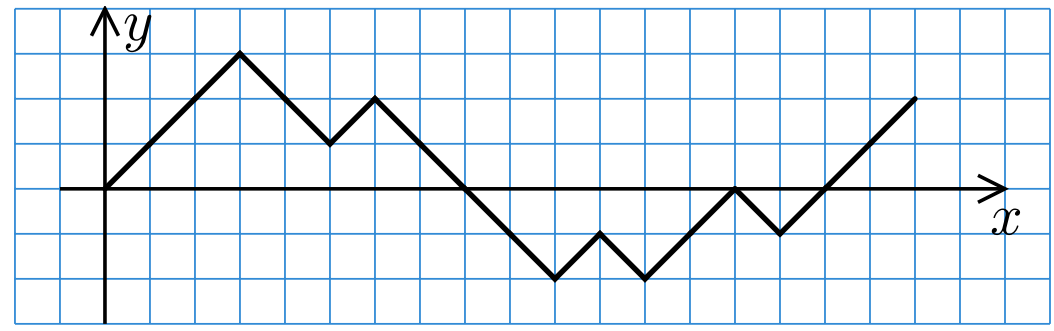

2.1. ábra: Példa egy útra

A „,(2-dimenziós) út” helyett élhetnénk az „1-dimenziós séta” szóhasználattal is, ahol az $x$-tengely megfelelője a diszkrét idő, az $y$-tengelyé pedig az aktuális pozíció lenne. Így talán koherensebbé válna a dolgozat nyelvezete, mégis inkább a szakirodalomban elterjedt elnevezéseket választottam.

Egy $n$ hosszú (absztrakt) út felfogható úgy is, mint egy $n$ elemú alaphalmaz egy részhalmazának karakterisztikus vektora, csak 0 és 1 számok helyett a $\nearrow$ és 】 szimbólumokkal kódolva. Tehát az utakkal voltaképpen csupán szokatlan módon vizualizáljuk a véges halmazokat. És mint látni fogjuk, ez a szemléltetés sokszor hasznosnak bizonyul mind problémamegoldás, mind leírás szempontjából. (Például a 2.4. alfejezetben ismertetett, középsố binomiális együtthatókra vonatkozó (2.5) konvolúciós formula esetén is utak segítségével érvel a legelemibb kombinatorikus bizonyítás, ami meglepóbb, mint Catalan-számokat tartalmazó formulák esetén.)

Az utak (illetve lépések) összefüzésére intuitív jelölést használunk: Például ha $L$ és $R$ egy út, akkor a $\nearrow L \searrow R$ út a következô lépéssorozatot jelenti: felfelé lépés, $L$ lépései, lefelé lépés, $R$ lépései (természetesen ebben a sorrendben, valamint az $L$-beli, illetve $R$-beli lépések sorrendjének megtartásával).

Az alábbiakban néhány speciális útosztályt definiálunk:

Definíció. Egy út

- kiegyensúlyozott, ha az $x$-tengelyen végződik, azaz ha ugyanannyi felfelé lépést tartalmaz, mint lefelé lépést;

- nemnegatív, ha soha nem megy az $x$-tengely alá;

- seholsem-zéró, ha soha sem lép rá az $x$-tengelyre (a kezdôpontot leszámítva);

- Dyck-út, ha nemnegatív és kiegyensúlyozott.

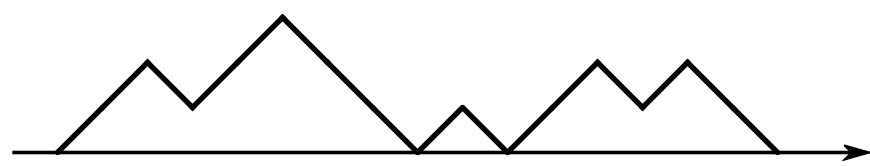

2.2. ábra: Egy Dyck-út

Ha egy $P$ kiegyensúlyozott út hossza $2 k$, akkor azt is mondjuk, hogy $P$ félhossza $k$. (Minden kiegyensúlyozott út páros sok lépésból áll, hiszen a felfelé és lefelé lépések száma megegyezik.) $\diamond$

Az imént definiált speciális utak száma ismert tetszóleges rögzített hosszra: 


\section{2. Állítás.}

a) $A 2 n$ hosszú (n félhosszú) kiegyensúlyozott utak száma $B_{n}$.

b) $A 2 n$ hosszú nemnegatív utak száma $B_{n}$.

c) $A 2 n$ hosszú seholsem-zéró utak száma $B_{n}$.

Bizonyítás. a) Triviális, hiszen az $n$ felfelé és $n$ lefelé lépés sorrendjét tetszólegesen megválaszthatjuk.

b-c) Folklór állítások, több bizonyításuk is olvasható például [6]-ban. Bijekció megadásával igazolható, hogy a $2 n$ hosszú nemnegatív utak száma megegyezik a $2 n$ hosszú kiegyensúlyozott utak számával. Az pedig könnyen látható (szintén bijektíven), hogy a b)-beli és c)-beli utak száma megegyezik.

A következô állítás a BSc kombinatorika tananyag része, melyet a Catalanszámok kombinatorikus definíciójának tekintünk:

2.3. Állítás. $A 2 n$ hosszú ( $n$ félhosszú) Dyck-utak száma $C_{n}$.

A bevezetô alfejezetben említettük, hogy Stanley több mint 200 másik interpretációt gyưjtött össze. Shapiro azonosságán gondolkodva azonban előbb-utóbb úgy érezzük, hogy egyik sem segít közvetlenül (néhány sorban) megtalálni a bijektív bizonyítást. A megoldáshoz elvezetô interpretáció abban különbözik ezektól, hogy csak páros indexú Catalan-számokra vonatkozik, azaz megragadja az indexek párosságát. Nézzük tehát a kulcsdefiníciót és a fólemmát:

Definíció. Egy út páros-metszô, ha az x-tengelyt csak 4-gyel osztható (abszcisszájú) pontokban metszi. $\diamond$

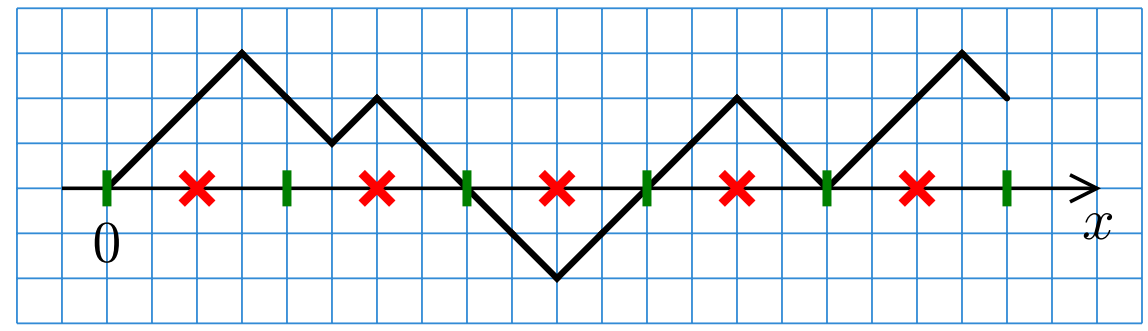

2.3. ábra: Egy páros-metszô út

Megjegyzés. Metszéspont alatt nemcsak átmetszést értünk, hanem annak tekintünk minden $x$-tengelyre lépést. Egy (origóból induló) út $x$-tengelymetszetei természetesen csak páros számok lehetnek, hiszen minden lépés után megváltozik az aktuális magasság paritása. Páros-metszô utak esetén tehát minden második lehetséges $x$-tengelymetszet tiltott (lásd 2.3. ábra). Innen ered a kissé mesterkélt páros-metsző elnevezés is: csak a párosadik metszéspontok megengedettek a szóba jöhetôek közül. $\diamond$

A következő lemmában adjuk meg a páros indexű Catalan-számok ígért kombinatorikus leírását. A lemma története kalandos: 1981-ben American Mathematical Monthly problémaként [25] tûzték ki. (Megfogalmazása csak annyiban tér el lemmánkétól, hogy $45^{\circ}$-kal elforgatott szemléletben dolgozik.) 1983-ban közöltek 
egy hibás, majd 1985-ben egy kombinatorikus, de nem bijektív megoldást [3]. Ekkor a szerkesztők újra kitüzték a feladatot, bijektív bizonyítást kérve, és 1987-ben megjelent Nichols et al. bijektív bizonyítása [19]. Ezután a lemma elfelejtődött, legalábbis erre utal, hogy Shapiro formuláját sokáig nem sikerült kombinatorikusan igazolni. (Ugyanis ahogy a legtöbb ilyen problémánál, itt is a megfelelő összeszámlálási feladat megtalálása a nagyobb nehézség, nem a megoldása.) Érdekesség, hogy a lemmát Monthly-feladatként szintén Shapiro tûzte ki, és Stanley Enumerative Combinatorics könyvében is szerepel [32; 230. o., 6.22], csak nem a Catalan-számok ekvivalens definícióit tartalmazó hosszú listában, amely talán a legolvasottabb összefoglaló a témában, hanem külön feladatként. A 2012-es [16] cikkem írásakor ezekról az előzményekrôl nem volt tudomásom, és sajnos hivatkozás nélkül fogalmaztam meg és bizonyítottam a lemmát (amely bizonyítás egyébként megegyezik Nicholsék megoldásával), és így is jelent meg; ez a 2014-ben megjelent [12] cikkünkben tisztázásra került.

2.4. Lemma. (Nichols et al. [19]) A $4 n$ hosszú (2n félhosszú) kiegyensúlyozott párosmetszó utak száma $C_{2 n}$.

Bizonyítás. $n=0$ esetén nyilvánvalóan teljesül az állítás, rögzítsünk tehát egy tetszóleges $n \geq 1$ számot. Jelölje a $4 n$ hosszú Dyck-utak halmazát $\mathcal{D}$, a lemmabeli utak halmazát pedig $\mathcal{E}$. Mivel $|\mathcal{D}|=C_{2 n}$ a Catalan-számok standard interpretációja (2.3. Állítás) szerint, ezért elegendő egy bijekciót megadnunk $\mathcal{D}$ és $\mathcal{E}$ között.

Tekintsünk egy tetszóleges $\mathcal{D}$-beli $D$ Dyck-utat. $D$ képének definiálásához először keressük meg az elsố olyan lefelé lépést $D$-ben, amellyel az út visszatér az $x$-tengelyhez. Ha ezt a lépést a kezdólépéssel együtt eltávolítjuk $D$-ból, akkor $D$ két Dyck-útra esik szét: Jelölje $L$ a bal oldalit, $R$ pedig a jobb oldalit. (Például $L$ azért Dyck-út, mert egyrészt nyilván kiegyensúlyozott, másrészt az eltávolított lefelé lépés volt az elsô olyan lépés $D$-ben, mely az 1 magasság alá lép, így a nemnegativitás is teljesül.) Mivel $D$ félhossza páros $(2 n)$, és egy lépéspárt eltávolítottunk $D$-ból, ezért $L$ és $R$ közül az egyik félhossza páros, a másiké páratlan (mert ezen félhosszok összege páratlan, $2 n-1)$.

1. eset: Ha $R$ a páratlan félhosszú Dyck-út, akkor $D$ képe legyen $\phi(D):=\nearrow R \searrow \phi(L)$, ahol $\phi(L)$-t úgy kapjuk, hogy a fenti eljárást rekurzív módon megismételjük az $L$ páros félhosszú Dyck-útra (mint „új $D$ ”-re) mindaddig, amíg a 0 hosszú úthoz nem jutunk, amelyre $\phi(\varepsilon):=\varepsilon$. (A fenti $L-R$-felbontást minden páros, de nem nulla félhosszú Dyck-útra el tudjuk végezni.)

2. eset: Ha $L$ a páratlan félhosszú Dyck-út, akkor $D$ képe legyen $\phi(D):=\searrow \bar{L} \nearrow \phi(R)$, ahol $\bar{L}$ az $L$ út $x$-tengelyre vonatkozó tükörképe (azaz $\bar{L}$-t a felfelé és lefelé lépések felcserélésével nyerjük $L$-ból), és $\phi(R)$-et úgy kapjuk, hogy a fenti eljárást rekurzív módon megismételjük a páros félhosszú $R$-re.

Tehát az imént tulajdonképpen egy, a páros félhosszú Dyck-utak halmazán értelmezett $\phi$ függvényt definiáltunk rekurzív módon. (A definíció értelmes, mert az 1. és 2. esetben is páros félhosszú az a Dyck-út, amelyre újból kiértékeljük $\phi$-t.) A $\psi:=\left.\phi\right|_{\mathcal{D}}$ függvény lesz a keresett bijekció. $\psi$ definíciója és a bijektivitás ellenôrzése legkönnyebben a 2.4. ábra alapján követhetô (a felsố $D$ út képe az alsó $E$ út): 
A kódolás I. fázisában a zöld hullámos lépéspárral osztjuk fel $D$-t $L_{1}$-re és $R_{1}$-re (a fenti $L$ és $R$ jelöléshez hozzávettük a fázis sorszámát indexként, de $L_{1}$-et nem jelöltük az ábrán), melyek közül a zöld hagyományos vonallal rajzolt $R_{1}$ Dyck-út a páratlan félhosszú, így az 1. eset alapján végezzük el a kódolást, mellyel a képként adódó $E$ út zöld lépéseit kapjuk meg, és következik a II. fázis. A II. fázisban a $D$-ból megmaradó (nem zöld) útban a piros hullámos lépéspár adja az $L_{2}-R_{2}$-felbontást, melyek közül az $L_{2}$ a páratlan félhosszú, így most a 2. eset alapján kódolunk. Végül a III. fázisban ismét egy 1. esetbeli kódolás következik a $D$-ből megmaradt útra, kék színekkel jelölve, és ezzel ,átdaraboltuk" az egész $D$ utat az $E$ úttá $\left(L_{3}=\varepsilon\right)$, az algoritmus leáll.
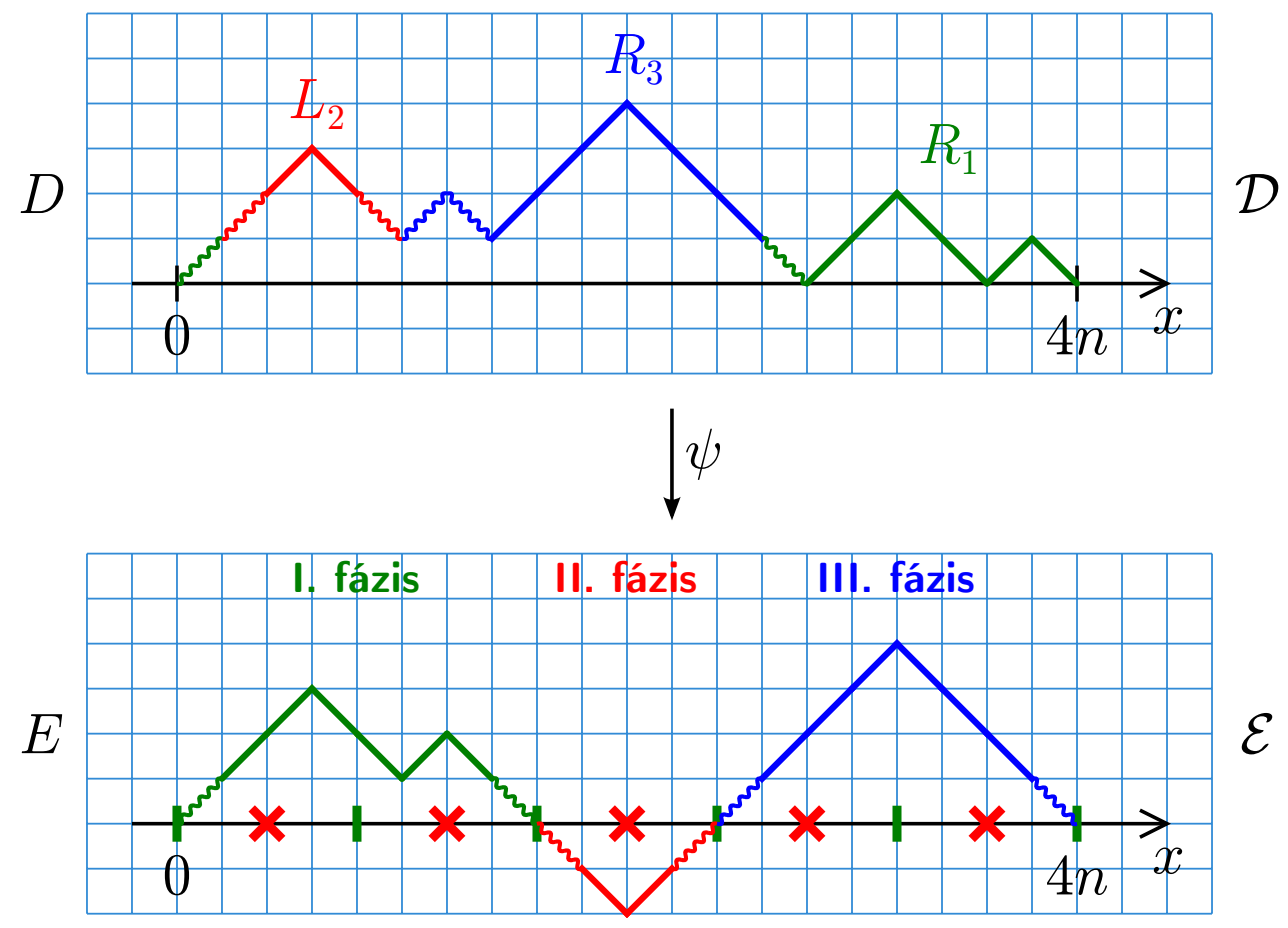

2.4. ábra: A lemmát bizonyító bijekció

Hátravan még annak végiggondolása, hogy $\psi$ valóban $\mathcal{D} \rightarrow \mathcal{E}$ bijekció. Könnyư látni, hogy tetszóleges $D \in \mathcal{D}$ esetén $\psi(D) \in \mathcal{E}$ teljesül: $\psi$ hossztartása világos (azaz $4 n$ hosszú utat kapunk a kódolás végén), minden fázisban az $L-R$-felosztást adó lépéspárt és a páratlan félhosszú utat „másoljuk át” $\psi(D)$-be, akár az 1. eset, akár a 2. eset szerint kódolunk. (Formálisan: $\phi$ hossztartása az argumentum félhossza szerinti indukcióval egyszerúen igazolható. Hasonlóan bizonyítható a $\psi$ bijektivitásához szükséges összes többi tulajdonság, mi azonban indukcióra való hivatkozás helyett inkább a szemléletesebb megfogalmazásokat választjuk.) $\psi(D)$ felépítésekor minden fázisban egy kiegyensúlyozott utat „ragasztunk” a már felépített részhez, ezért egy kiegyensúlyozott utat kapunk végeredményül is. Mivel minden fázisban olyan (hagyományos vagy tükrözött) Dyck-utat ragasztunk, amely a kezdô- és végpontot leszámítva nem metszi az $x$-tengelyt, ezért minden fázisban két szomszédos $x$-tengelymetszet közötti részt építünk fel $\psi(D)$-ben. Az algoritmus minden 
fázisban páratlan félhosszú Dyck-utat választ, tehát bármely két zérushely között a hozzáadott („hullámos”) lépéspárral együtt páros félhosszú, azaz 4-gyel osztható hosszúságú Dyck-út áll (esetleg tükrözve). Ez pedig pontosan azt jelenti, hogy $\psi(D)$ páros-metszố út is, azaz $\psi(D) \in \mathcal{E}$.

Belátjuk, hogy tetszőleges $E \in \mathcal{E}$ útnak egyetlen inverz képe van. Az $x$ tengelymetszetek felosztják a $E$-t (esetleg tükrözött) Dyck-utakra, melyek elsô és utolsó lépését eltávolítva páratlan félhosszú Dyck-utakat kapunk, amelyek a fázisoknak felelnek meg. Abból, hogy egy ilyen Dyck-út tükrözött vagy sem, kitalálhatjuk, hogy a feltételezett ősképbeli megfelelője bal oldali vagy jobb oldali út volt-e az adott fázisban (azaz az 1. vagy 2. eset szerint kódoltunk-e), és ennek segítségével balról jobbra haladva egyértelmúen felépíthetjük az inverz képet. Például a 2.4. ábrán látható $E$ út esetén tudjuk, hogy az első $x$-tengelymetszetig tartó rész felel meg az 1. fázisnak, amelyben 1. esetbeli konverzió történt (mivel nem volt tükrözés), ebbôl $\psi$ definíciója alapján világos, hogy ezt a „kezdőszeletet” akkor és csak akkor kaphatjuk meg, ha a feltételezett ôskép vonatkozó része megegyezik az ábra felsô felén látható $D$ Dyck-út zöld színú részével, és a két zöld hullámos lépés között nincs $x$-tengelyre vivố lépés benne. (Itt felhasználjuk azt is, hogy a zöld hagyományos vonallal rajzolt út félhossza páratlan, máskülönben a kódoló algoritmus a másik részutat választaná a fázisban.) Ezután a kék lépések „ôsét” tudjuk egyértelmúen meghatározni, és így tovább balról jobbra (fázisról fázisra) haladva megtalálhatjuk az inverz képet, unicitási érveléssel együtt. Ezzel beláttuk $\psi$ bijektivitását, így bizonyításunk teljes.

Megjegyzés. Informálisan fogalmazva, a $\mathcal{D}$-beli és az $\mathcal{E}$-beli utakat is páratlan félhosszú Dyck-utakból építhetjük fel, és bijekciónk a $\mathcal{D}$-beli utak felépítésének „balra/jobbra” döntéseit konvertálja át az $\mathcal{E}$-beli utak felépítésének „felfelé/lefelé” döntéseivé.

A lemmabeli utak számát $X_{n}$-nel, a $C_{2 n}$ Catalan-számot $Y_{n}$-nel jelölve könnyen látható, hogy az $\left(X_{n}\right)_{n=0}^{\infty}$ és $\left(Y_{n}\right)_{n=0}^{\infty}$ sorozat is kielégíti a következố rekurziót (és emiatt megegyeznek):

$$
\begin{aligned}
& Z_{0}=1 ; \\
& Z_{n}=2 \sum_{k=1}^{n} C_{2 k-1} Z_{n-k}, \text { ha } n \geq 1 .
\end{aligned}
$$

Ugyanis a lemmabeli utakat elsố nem-origó $x$-tengelymetszetük szerint osztályozva azonnal megkapjuk, hogy $\left(X_{n}\right)_{n=0}^{\infty}$ valóban kielégíti a rekurziót, az $\left(Y_{n}\right)_{n=0}^{\infty}$ sorozatra vonatkozóan pedig (2.3) csak a standard (2.1) Catalan-rekurzió átfogalmazása. Ez egy rekurzív bizonyítás, melyre azonban jóval egyszerúbb rátalálni, hiszen (2.3) természetes módon adódik, amikor megpróbáljuk összeszámolni a lemmabeli utakat. (A lemma történeti áttekintésében említett elsô kombinatorikus bizonyítás is így érvel [3].) Valójában $\psi$ kódolásunk ezt a rekurzív gondolatmenetet „bijektivizálja". $\diamond$

A fenti lemmából azonnal következik a páros indexú Catalan-számok konvolúciójának egy kombinatorikus interpretációja: 


\subsection{Következmény.}

a) $\sum_{k=0}^{n} C_{2 k} C_{2 n-2 k}$ az origóból a $(4 n+1,1)$ pontba menó páros-metszó utakat számolja meg.

b) $\sum_{k=0}^{n} C_{2 k} B_{2 n-2 k}$ a $4 n$ hosszú páros-metszó utakat számolja meg.

Bizonyítás. a) Csoportosítsuk a szóban forgó utakat az utolsó $x$-tengelymetszetük szerint. (Ez értelmes, hiszen az origó mindig $x$-tengelymetszet.) $C_{2 k} C_{2 n-2 k}$ azon lemmabeli utakat számolja meg, melyek utolsó $x$-tengelymetszete $4 k$, hiszen $C_{2 k}$ lehetôség van páros-metszố módon eljutni az origóból a $(4 k, 0)$ pontba a 2.4 . Lemma alapján, majd ezután felfelé lépésnek kell következnie (hiszen az $x$-tengelyre innentól nem léphetünk rá, és a végpont az $x$-tengely fölött van), végül a $(4 k+1,1)$ pontból $C_{2 n-2 k}$-féleképpen juthatunk el a $(4 n+1,1)$ pontba $x$-tengelyre lépés nélkül a 2.3. Állítás szerint (hiszen ez a szakasz nyilvánvalóan egy $4 n-4 k$ hosszú Dyckút további megkötés nélkül). A formula valóban a lemmabeli utakat számolja meg, mivel a páros-metszó tulajdonság miatt az utolsó $x$-tengelymetszet mindig $4 k$ alakú valamely $k \in\{0, \ldots, n\}$ számra.

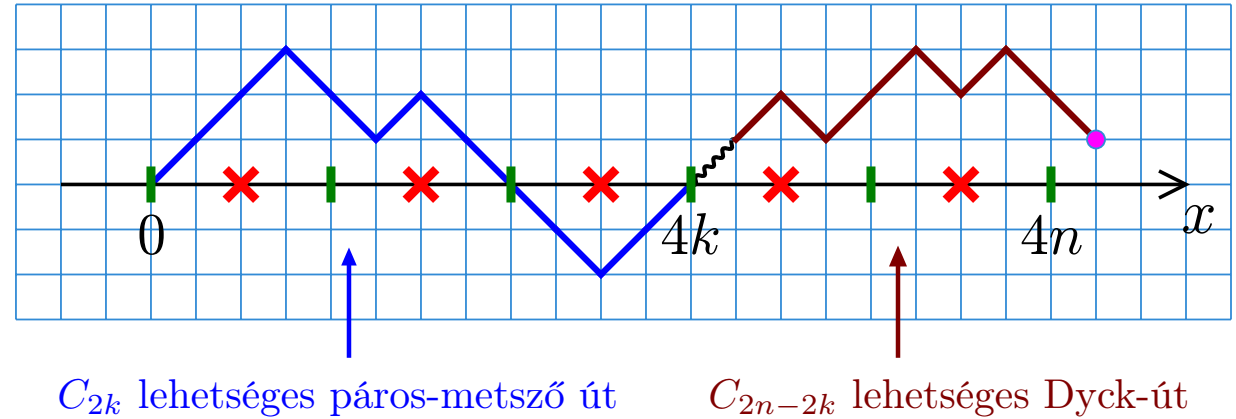

2.5. ábra: $\mathrm{Az}$ a) állítás bizonyítása

b) Analóg módon adódik az állítás. $C_{2 k} B_{2 n-2 k}$ azon lemmabeli utakat számolja meg, amelyek utolsó $x$-tengelymetszete $4 k$, ugyanis ezen utak $(0,0) \rightsquigarrow(4 k, 0)$ szakasza ismét $C_{2 k}$-féleképpen valósulhat meg (2.4. Lemma), majd a $(4 k, 0)$ ponttól $B_{2 n-2 k}$-féleképpen folytatódhatnak seholsem-zéró módon (2.2. Állítás).

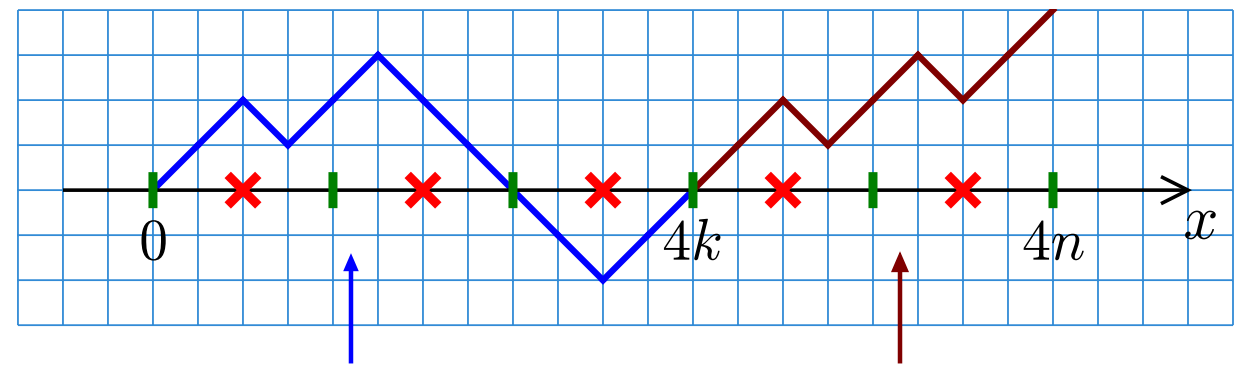

$C_{2 k}$ lehetséges páros-metszố út $\quad B_{2 n-2 k}$ lehetséges seholsem-zéró út

\section{6. ábra: A b) állítás bizonyítása}

A 2.5. Következményben szereplô két konvolúció között szoros kapcsolat van: 


\subsection{Lemma.}

$$
\sum_{k=0}^{n} C_{2 k} B_{2 n-2 k}=(n+1) \sum_{k=0}^{n} C_{2 k} C_{2 n-2 k} .
$$

Bizonyítás. Felhasználva a $B_{j}=(j+1) C_{j}$ összefüggést,

$$
\begin{aligned}
\sum_{k=0}^{n} C_{2 k} B_{2 n-2 k} & =\sum_{k=0}^{n} C_{2 k}(2 n-2 k+1) C_{2 n-2 k} \\
& =\frac{1}{2}\left(\sum_{k=0}^{n} C_{2 k}(2 n-2 k+1) C_{2 n-2 k}+\sum_{k=0}^{n} C_{2 n-2 k}(2 k+1) C_{2 k}\right) \\
& =\frac{1}{2} \sum_{k=0}^{n}(2 n+2) C_{2 k} C_{2 n-2 k}=(n+1) \sum_{k=0}^{n} C_{2 k} C_{2 n-2 k}
\end{aligned}
$$

Megjegyzés. $B_{j}$-t és $C_{j}$-t alkalmas összeszámlálási problémára adott válaszként értelmezve (2.2. és 2.3. Állítás) a fenti számolás átkonvertálható bijektív bizonyítássá, ha felhasználjuk a $B_{j}=(j+1) C_{j}$ tény egy bijektív - pl. [6]-ban olvasható bizonyítását. Erre azonban nincs szükség, ugyanis Shapiro azonosságának bijektív bizonyításakor nem fogjuk használni ezt a lemmát a 2.3. alfejezetben; kombinatorikus bizonyításunkban pedig a fó nem bijektív gondolat a 2.7. Lemma lesz, így a fenti számolás kiküszöbölése sem segítene. $\diamond$

Shapiro (2.2) konvolúciós formuláját $(n+1)$-gyel szorozva, a 2.6. Lemma és az $(n+1) C_{n}=B_{n}$ összefüggés alapján a

$$
\sum_{k=0}^{n} C_{2 k} B_{2 n-2 k}=4^{n} B_{n}
$$

ekvivalens alakot kapjuk.

A Shapiro-formula igazolásához elegendő a 2.5. Következmény a) pontjában szereplố utakat másképp megszámolni, $4^{n} C_{n}$ választ eredményezố módon. Hasonlóan, a (2.4) ekvivalens alakhoz pedig a b) pontban szereplő utak számáról kell belátni, hogy $4^{n} B_{n}$.

Tulajdonképpen a 2.7. ábrán szemléltetett középiskolás módszerrel számoljuk össze a kérdéses utakat: Ha az ábrán látható módon minden szóba jöhetô rácspontra fel akarjuk jegyezni, hogy hányféleképpen lehet oda páros-metszó módon eljutni az origóból, akkor az ábra balról jobbra haladva „kitölthetơ”, ugyanis minden pont címkéje a bal oldali szomszédok címkéinek összege (a szomszédságot a berajzolt vonalak szemléltetik), hiszen először ezen szomszédok valamelyikébe kell eljutni, és utána egy egyértelmúen meghatározott lépés következik a vizsgált pontba. (Ez az egyszerú gondolat elvezet egy hatékony algoritmushoz, mellyel gyorsan ki lehet számolni számítógép segítségével ezeket az értékeket nagyobb koordinátájú rácspontokra is. De erre nem lesz szükségünk.) Eddigi eredményeink a következôképpen 
foglalhatók össze: Tudjuk, hogy a $(4 n, 0)$ pont címkéje $C_{2 n}$ a 2.4. Lemma szerint; a $(4 n+1, \pm 1)$ pont címkéje $L_{n}:=\sum_{k=0}^{n} C_{2 k} C_{2 n-2 k}$, a $4 n$-edik oszlopban lévố címkék összege pedig $S_{n}:=\sum_{k=0}^{n} C_{2 k} B_{2 n-2 k}$ a 2.5. Következmény szerint. Azt kell megmutatnunk, hogy $L_{n}=4^{n} C_{n}$, vagy ami ezzel ekvivalens, hogy $S_{n}=4^{n} B_{n}$. A fô észrevétel az, hogy $S_{n+1}$ kiszámolható $S_{n}$ és $L_{n}$ segítségével, azaz a 2.6. Lemma $L_{n}=\frac{1}{n+1} S_{n}$ összefüggését figyelembe véve $S_{n}$ segítségével, amiból egy rekurzív kiszámítási módot kapunk a keresett $S_{n}$, illetve $L_{n}$ értékekre.

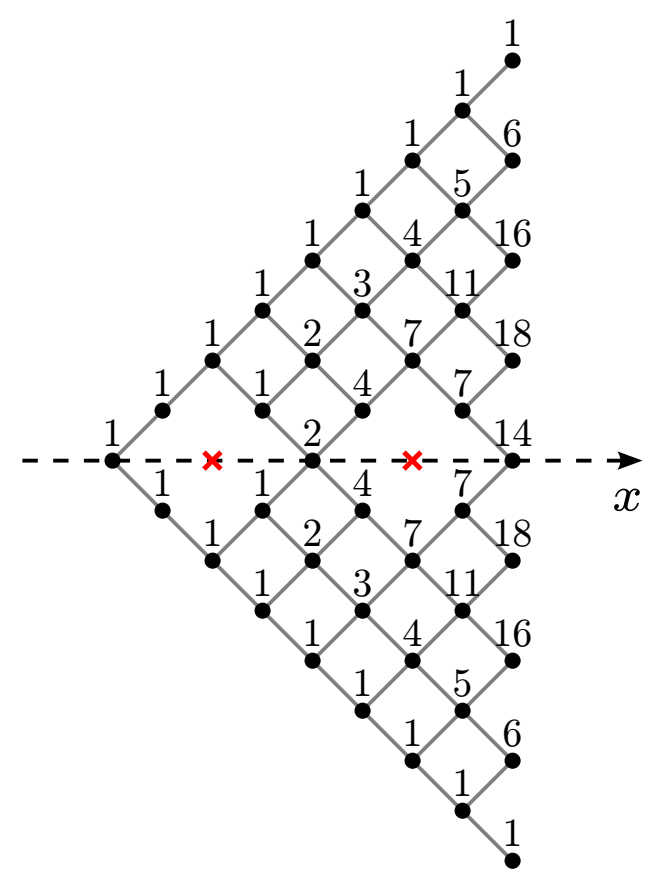

2.7. ábra: A páros-metszô utak száma

A részleteket a következố lemma tárgyalja (címkék helyett tömörebb nyelvezetet használva), amely egyúttal Shapiro azonosságára adott kombinatorikus bizonyításunk befejező lépése (vö. 2.5. Következmény):

\subsection{Lemma.}

a) Az origóból a $(4 n+1,1)$ pontba menô páros-metszó utak száma $4^{n} C_{n}$.

b) $A 4 n$ hosszú páros-metszó utak száma $4^{n} B_{n}$.

Bizonyítás. A 2.5. Következmény szerint az a)-beli utak száma $\sum_{k=0}^{n} C_{2 k} C_{2 n-2 k}$, a b)-beli utak száma pedig $\sum_{k=0}^{n} C_{2 k} B_{2 n-2 k}$. A 2.6. Lemma alapján tehát a b)-beli utak száma $(n+1)$-szerese az a)-beli utak számának, így a két állítás ekvivalens, hiszen ez az összefüggés a bizonyítandó értékekre is fennáll.

A b) állítást látjuk be. Jelölje a $4 n$ hosszú páros-metszô utak halmazát $\mathcal{P}_{n}$, és legyen $S_{n}:=\left|\mathcal{P}_{n}\right|$. A bizonyítandó $S_{n}=4^{n} B_{n}$ állítást $n$ szerinti indukcióval igazoljuk. Ez nyilvánvalóan teljesül $n=0$ esetén. Tegyük fel, hogy $n$-re igaz, hogy $S_{n}=4^{n} B_{n}$. Minden $\mathcal{P}_{n+1}$-beli utat egyértelmúen megkaphatunk valamely $\mathcal{P}_{n}$-beli útból 4 alkalmas befejező lépés hozzávételével. Egy utat 16-féleképpen lehet meghosszabbítani 4 lépéssel, így a $\mathcal{P}_{n}$-beli utak mindegyikét meghosszabbítva összesen 
$16 S_{n}$ különbözô utat kapunk. Ezek közül pontosan azok nincsenek $\mathcal{P}_{n+1}$-ben, melyek rálépnek a $(4 n+2,0)$ pontra. (Hiszen ezen utak első $4 n$ lépése $\mathcal{P}_{n}$-beli utat alkot, így ott soha nem következhet be tiltott $x$-tengelyre lépés.) A $(4 n+2,0)$ pontra a $(4 n+1,1)$ és $(4 n+1,-1)$ pontok valamelyikéról lehet lehet rálépni. Tehát a „rossz” meghosszabbítások pontosan azok az utak, amelyek elôször páros-metszó módon eljutnak a $(4 n+1,1)$ pontba, majd egy (tiltott) lefelé lépés és két tetszóleges lépés következik; továbbá ezen utak $x$-tengelyre vonatkozó tükörképei - utóbbiak adják meg azokat a rossz utakat, amelyek a $(4 n+1,-1)$ pontból lépnek a tiltott $(4 n+2,0)$ pontra.

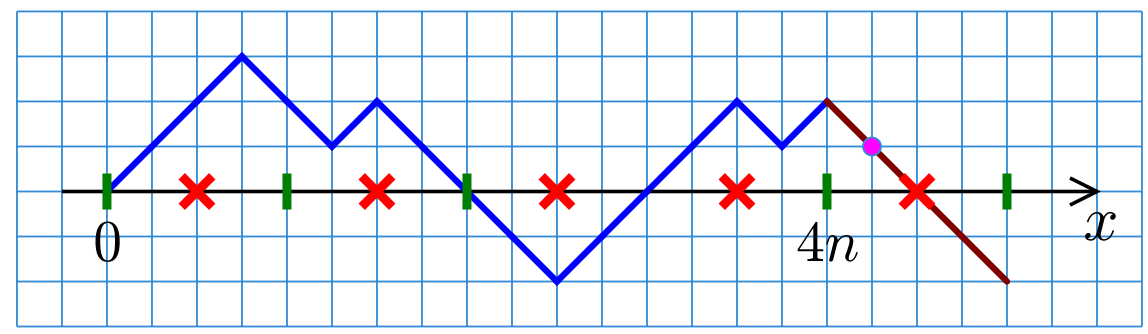

2.8. ábra: Egy rossz meghosszabbítás

Az elsó bekezdésben végiggondoltuk, hogy az origóból a $(4 n+1,1)$ pontba menô páros-metszố utak száma $\frac{1}{n+1} S_{n}$, tehát a rossz meghosszabbítások száma $\frac{8}{n+1} S_{n}$. (A 8-as szorzó a két tetszőleges záró lépésból és a tükrözött utak miatti duplázódásból jön.) Eddigi észrevételeinket összegezve, az $S_{n}=4^{n} B_{n}$ indukciós feltevés felhasználásával

$$
S_{n+1}=16 S_{n}-\frac{8}{n+1} S_{n}=16 \cdot 4^{n} B_{n}-\frac{8}{n+1} 4^{n} B_{n}=4^{n+1} B_{n+1}
$$

adódik, amit bizonyítani kellett. (Az utolsó egyenlôség egyszerû számolással ellenôrizhetô a $B_{n}=\left(\begin{array}{c}2 n \\ n\end{array}\right)$,számszerúsített" definícióból.)

\subsection{A bijektív bizonyítás}

A következókben a (2.2) Shapiro-azonosság bijektív bizonyítását ismertetjük. Érvelésünk következményeként a Catalan-számok egy új interpretációját is megkapjuk, melyet az alfejezet végén külön állításban is megfogalmazunk. Ezeket az eredményeket témavezetômmel, Hajnal Péterrel közös cikkben publikáltam [12].

Az előző alfejezet kombinatorikus gondolatmenetét tesszük teljesen bijektívvé. A Catalan-számok Dyck-utas kombinatorikus definíciójából (2.3. Állítás) kiindulva bijektív módon igazoltuk a 2.5.a Következményt (a lényegi rész a 2.4. Lemma bizonyítása volt), tehát már csak a 2.7.a Lemma bijektív bizonyítása maradt hátra. Ez több lépésból fog állni, és előrebocsátjuk, hogy mindig bijekció megadásával fogunk érvelni, de ezt nem hangsúlyozzuk a továbbiakban. Az „elegendó a következôt bizonyítani" célokat lemmaként fogalmazzuk meg, melyek bizonyítása a hosszú gondolatmenet végén, a 2.10. Lemma igazolásával zárul majd le. Természetesen továbbra is használjuk az előzô alfejezetben bevezetett fogalmakat és jelöléseket, 


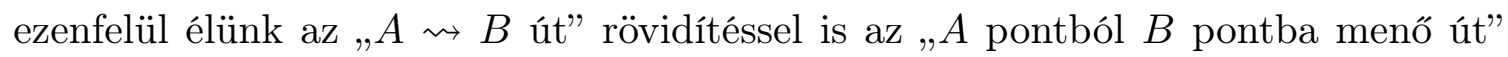
leírására.

Rögzítsük $n$-et. Azt kell igazolnunk bijektíven, hogy az origóból a $(4 n+1,1)$ pontba menó páros-metszố utak száma $4^{n} C_{n}$. Célunkat technikai okokból átfogalmazzuk. Ha eltekintünk az elsô lépéstól, azt is mondhatjuk, hogy azt kell belátni, hogy az $(1,1) \rightsquigarrow(4 n+1,1)$ páros-metszố és az $(1,-1) \rightsquigarrow(4 n+1,1)$ páros-metsző utak száma összesen $4^{n} C_{n}$. Az $(1,-1) \rightsquigarrow(4 n+1,1)$ páros-metszô utak száma szimmetriai okokból nyilvánvalóan megegyezik az $(1,1) \rightsquigarrow(4 n+1,-1)$ páros-metszó utak számával. (Az $x$-tengelyre való tükrözés bijekciót létesít a két úthalmaz között.) Tehát a következô alakban is megfogalmazhatjuk a bizonyítandót (a két lehetséges végpont tömör jelölésével):

2.8. Lemma. $A z(1,1) \rightsquigarrow(4 n+1, \pm 1)$ páros-metszố utak száma $4^{n} C_{n}$.

A lemmabeli utak halmazát $\mathcal{E}$ jelöli a továbbiakban; a 2.9. ábra bal oldalán $\mathcal{E}$ egy útja látható ( $n=4$ esetén). Csak minden negyedik lépés tudja megsérteni a páros-metszó tulajdonságot: az elsô, ötödik, kilencedik stb. lépések azok, amelyekkel az $x$-tengely egy tiltott pontjára léphetünk az $(1,1)$ pontból indulva. Ez motiválja a lépések következô felosztását és tömörítési eljárásunkat: Egy tetszôleges, $(1,1)$ kezdốpontú, $4 n$ hosszú $P$ útra $o_{1} \boldsymbol{e}_{\mathbf{1}} O_{2} \boldsymbol{e}_{\mathbf{2}} \ldots o_{n} \boldsymbol{e}_{\boldsymbol{n}}$ alakban tekintünk, ahol $o_{i}$ egy hagyományos felfelé vagy lefelé lépés, $\boldsymbol{e}_{\boldsymbol{i}}$ pedig egy három lépésból álló út, azaz $o_{i} \in\{\nearrow, \searrow\}$ és $\boldsymbol{e}_{\boldsymbol{i}} \in\{\nearrow, \searrow\}^{3}$. Minden $\boldsymbol{e}_{\boldsymbol{i}}$ lépéshármast egyetlen $\boldsymbol{e}_{\boldsymbol{i}}^{*}$ szimbólummal (általánosított lépéssel) kódolunk: a $\searrow \nearrow \nearrow, \nearrow \searrow \nearrow$ és $\nearrow \nearrow \searrow$ lépéssoroza-

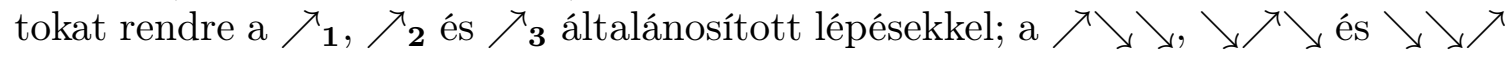
lépéssorozatokat a $\searrow_{1}, \searrow_{\mathbf{2}}$ és $\searrow_{\mathbf{3}}$ általánosított lépésekkel; továbbá a $\nearrow \nearrow \nearrow$ és $\searrow \searrow \searrow$ lépéssorozatokat rendre az $(1,3)$ és $(1,-3)$ általánosított lépésekkel helyettesítjük; így a $P^{*}:=o_{1} \boldsymbol{e}_{\mathbf{1}}^{*} o_{2} \boldsymbol{e}_{\mathbf{2}}^{*} \ldots o_{n} \boldsymbol{e}_{\boldsymbol{n}}^{*}$ általánosított úthoz jutunk. Az $\nearrow_{\mathbf{1}}, \ldots, \searrow_{\mathbf{3}}$ lépéseket (3-cimkézett) rövid lépéseknek, az $(1,3)$ és $(1,-3)$ lépéseket pedig hosszú lépéseknek nevezzük. Azokat az általánosított utakat, amelyekben minden párosadik lépés vagy hosszú lépés, vagy 3-címkézett rövid lépés (és minden páratlanadik lépés címkézetlen rövid lépés), tömörített utaknak nevezzük. Eljárásunk tehát a $P$ úthoz egy $P^{*}$ tömörített utat rendel, sôt, bijekciót létesít a $4 n$ hosszú utak halmaza és a $2 n$ hosszú tömörített utak halmaza között, mivel az $\boldsymbol{e}_{\boldsymbol{i}} \mapsto \boldsymbol{e}_{\boldsymbol{i}}^{*}$ átalakításokat definiáló szabály invertálható. (Értelemszerüen az általánosított utak hossza alatt is a lépések számát értjük.)
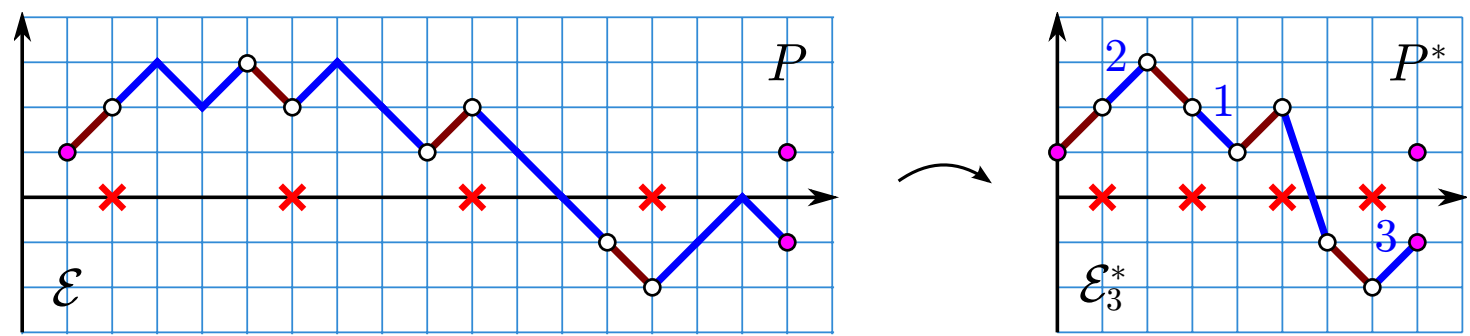

2.9. ábra: Tömörítés 
A fenti tömörítési eljárást a 2.9. ábra illusztrálja (egy $\mathcal{E}$-beli útra). Természetesen az ábra jobb oldalán látható módon szemléltetjük (és értelmezzük) az eredményül kapott $P^{*}$ általánosított utat. ( $P^{*}$-ot a $(0,1)$ pontból indítva rajzoljuk le, tehát $P$ kiindulópontjához képest 1 egységgel eltoljuk balra.) Informálisan, a $P^{*}$ tömörített útban megtartjuk $P$,veszélyes" lépéseit, azaz a bordó színnel jelölt, $(4 t+1)$-edik lépéseket $\left(t \in \mathbb{N}_{0}\right)$; a veszélyes lépések 3 lépésból álló (kék színnel jelölt) blokkokra osztják $P$-t, ezeket tömören írjuk le $P^{*}$-ban: ,összenyomjuk” óket 1 lépéssé (a blokkok kezdő magasságáról egyetlen lépéssel a végpontbeli magasságra lépünk), a címkék pedig azt az információt tárolják, hogy egy rövid lépés a három szóba jöhetô blokk közül melyikből jött létre. Tehát tulajdonképpen $P^{*}$ csupán $P$ egy másfajta „lerajzolása”.

Az $\mathcal{E}$-beli utakat jellemezhetjük tömörített alakjukkal is. Egy $4 n$ hosszú $P$ út pontosan akkor $\mathcal{E}$-beli, ha $P^{*}$-ra teljesülnek a következók:

(i) A $(0,1)$ pontból indulva a $(2 n, 1)$ vagy $(2 n,-1)$ pontban végződik;

(ii) minden párosadik lépése vagy hosszú lépés, vagy 3-címkézett rövid lépés (és minden páratlanadik lépése címkézetlen rövid lépés);

(iii) soha nem lép az $x$-tengelyre (de ,átugorhatja").

A (ii) feltételben csak elismételtük a tömörített út definíciójául szolgáló alaptulajdonságokat. Eljárásunk egy $4 n$ hosszú útból $2 n$ hosszú tömörített utat készít, és $P^{*}$ végpontjának magassága megegyezik $P$ végpontjának magasságával, ebból kapjuk az (i) feltételt. A (iii) feltétel pedig a páros-metsző tulajdonság megfogalmazása a $P^{*}$ tömörített útra: $P$ pontosan akkor páros-metszô, ha a $(4 t+1)$-edik („bordó”) lépések nem lépnek rá az $x$-tengelyre, azaz ha $P^{*}$-ban a páratlanadik („bordó”) lépések nem lépnek rá az $x$-tengelyre (a párosadik lépések paritási okok miatt soha nem léphetnek rá).

$\mathrm{Az}$ (i)-(iii) feltételeknek eleget tevố utak halmazát $\mathcal{E}_{3}^{*}$ jelöli a továbbiakban. A fentiek alapján tömörítési eljárásunk bijekciót létesít $\mathcal{E}$ és $\mathcal{E}_{3}^{*}$ között, így elegendő az $\left|\mathcal{E}_{3}^{*}\right|=4^{n} C_{n}$ egyenlőséget bizonyítani a 2.8. Lemma igazolásához:

2.9. Lemma. $A z(i)$-(iii) feltételeknek eleget tevó (általánositott) utak száma $4^{n} C_{n}$.

A bijektív bizonyításhoz szükséges $4^{n} C_{n}$ elemú halmazt címkézett Dyck-utak segítségével definiáljuk. Azt mondjuk, hogy egy Dyck-út 4-cimkézett, ha minden párosadik lépése meg van címkézve a $\{0,1,2,3\}$ halmazból (a páratlanadik lépések pedig címkézetlenek). Jelölje a $2 n$ hosszú 4 -címkézett Dyck-utak halmazát $\mathcal{D}_{4}$. Mivel egy $2 n$ hosszú Dyck-út $n$ darab páros pozícióban álló lépését $4^{n}$-féleképpen címkézhetjük meg 4 címkével, ezért $\left|\mathcal{D}_{4}\right|=4^{n} C_{n}$, tehát elegendő megadnunk egy bijekciót $\mathcal{E}_{3}^{*}$ és $\mathcal{D}_{4}$ között a 2.9. Lemma bizonyításához. (Egy lépés pozíciója alatt azt értjük, hogy a lépés hányadik az utat meghatározó lépéssorozatban.) $\mathcal{E}_{3}^{*}$ útjai már tartalmaznak címkézett rövid lépéseket bizonyos páros pozíciókban. Bijekciónk egy $\mathcal{E}_{3}^{*}$-beli $T$ tömörített úthoz oly módon fog egy $D_{T} 2 n$ hosszú 4-címkézett Dyckutat rendelni, hogy $D_{T}$,alakja" (a címkék eltávolítása után kapott Dyck-út) és a 0 címkéi együtt kódolják $T$,alakját”, továbbá $D_{T}$ 1-2-3 címkéi $T$ címkéit kódolják (az 1-2-3 címkéket balról jobbra elolvasva ugyanazt a sorozatot kapjuk $D_{T}$-ben, mint 
T-ben), lásd 2.10. ábra. (A 4-címkézett Dyck-utakat a hagyományos lerajzoláshoz képest 1 egységgel eltoljuk felfelé. Látni fogjuk, hogy kódolásunkhoz ez a lerajzolás lesz természetes.)
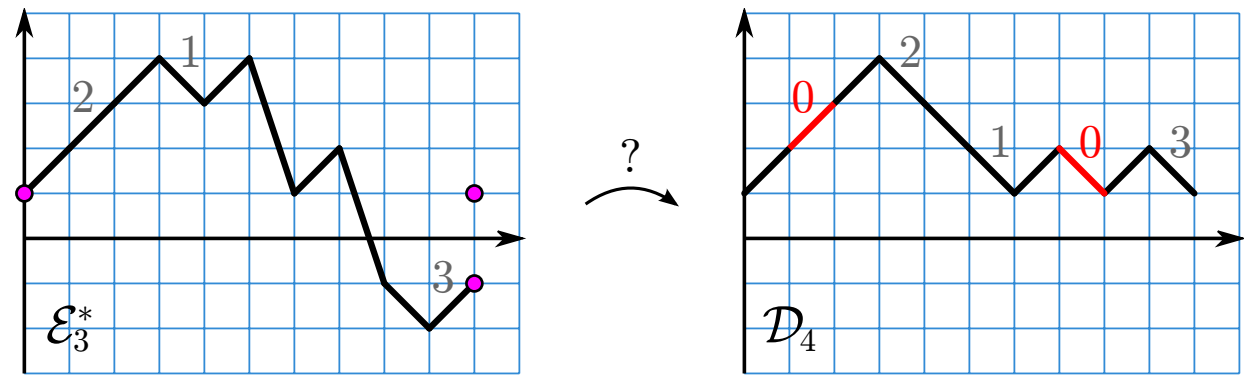

2.10. ábra: A keresett alakú bijekció illusztrációja

Persze ahhoz, hogy így tudjuk tárolni $T$ címkéit $D_{T}$-ben, szükséges, hogy a $T$ alakját kódoló (részlegesen címkézett) Dyck-útban a címkézetlen (0 címkét nem kapott) párosadik lépések száma megegyezzen a $T$-beli címkék számával (azaz $T$ páros pozícióban álló rövid lépései számával), más szóval a $T$ alakját kódoló Dyckútra ugyanannyi 0 címkét szeretnénk kiosztani, mint ahány hosszú lépés van $T$-ben.

A fentiek precíz megfogalmazásához jelölje $\mathcal{E}^{*}$ az $\mathcal{E}_{3}^{*}$-beli utak alakjainak halmazát, azaz azon $(0,1) \rightsquigarrow(2 n, \pm 1)$ (címkézetlen) utak halmazát, amelyek soha nem lépnek rá az $x$-tengelyre, továbbá a hagyományos $(1, \pm 1)$ rövid lépéseken túl tartalmazhatnak $(1, \pm 3)$ hosszú lépéseket is, kizárólag páros pozíciókban. $\mathcal{D}_{2}$ pedig legyen azon $2 n$ hosszú Dyck-utak halmaza, amelyekben minden párosadik lépés vagy jelölt (0 címkéjü) vagy jelöletlen (címkézetlen). A $\mathcal{D}_{2}$-beli utakat jelölt Dyckutaknak nevezzük. (Ábráinkon a jelölt lépések piros színúek.) A fentieket összegezve, a 2.9. Lemma következik az alábbi célkitüzésból:

2.10. Lemma. Létezik olyan $\phi: \mathcal{E}^{*} \rightarrow \mathcal{D}_{2}$ bijekció, hogy minden $E \in \mathcal{E}^{*}$ útra a $\phi(E)$ jelölt Dyck-útban ugyanannyi jelölt lépés van, mint ahány hosszú lépés szerepel Eben.

A lemmabeli bijekció segítéségével valóban azonnal megadható egy keresett $\psi: \mathcal{E}_{3}^{*} \rightarrow \mathcal{D}_{4}$ bijekció. Tetszóleges $Q \in \mathcal{E}_{3}^{*}$ útra a $Q$-ból a címkéi elhagyásával kapott $\left(\mathcal{E}^{*}\right.$-beli) utat $Q^{-}$-szal jelölve, a $\psi(Q)$ kép legyen az az út, amelyet $\phi\left(Q^{-}\right)$-ból kapunk oly módon, hogy a jelölt lépéseit 0 címkével látjuk el, majd a (páros pozíciókban álló) jelöletlen lépéseire átmásoljuk $Q$ címkéit, balról jobbra haladva. (A címkemásolás a $\phi$-re vonatkozó feltétel miatt lehetséges.) Egyszerúen meggondolható, hogy az így definiált $\psi$ függvény valóban $\mathcal{E}_{3}^{*} \rightarrow \mathcal{D}_{4}$ bijekció lesz.

Megjegyezzük, hogy a 2.10. Lemma állítása tovább nem erôsíthetô a kézenfekvố módon: $\phi$-tôl nem követelhetjük meg, hogy a $\phi(E)$-beli jelölt lépések pozíciói megegyezzenek az E-beli hosszú lépések pozícióival. Például könnyen ellenôrizhetó, hogy $n=2$ esetén $\mathcal{D}_{2}$-ben két olyan jelölt Dyck-út van, amelyben a második lépés az egyetlen jelölt lépés; míg $\mathcal{E}^{*}$-ban csak egy olyan út van, amelyben a második lépés az egyetlen hosszú lépés. Ez is mutatja a kódolás nehézségét; ha egy hosszú lépést rövid lépésre cserélünk, az út hátralévő része függőlegesen eltolódik, amit nehéz 
kontrollálni. Az általunk megadott bijekció sem lesz kézenfekvô, sôt, egyes elemei akár intuícióellenesnek is mondhatók. Ha az olvasó szeretné jobban megismerni a megtaláláshoz vezetố utat, akkor azt javasoljuk, hogy próbálja meg elôször csak az 1 (illetve 2) hosszú lépést tartalmazó $\mathcal{E}^{*}$-beli utakat kódolni 1 (illetve 2) jelölt lépést tartalmazó $D_{2}$-beli utakkal (bijektíven); vagy utólag, az általunk bemutatott általános eljárás megismerése után térjen vissza ezekhez a speciális esetekhez, és nézze meg, hogy $\phi$ kódolásunk megszorítása milyen megoldást ad a részproblémára. Ezen egyszerúbb esetek kezelése viszonylag természetes, melyekból általánosítással született a lemmát bizonyító bijekció.

Most rátérünk a 2.10. Lemma bizonyítására. Tekintsünk egy tetszóleges $E$ utat $\mathcal{E}^{*}$-ból. Mivel minden lépés során az aktuális magasság paritása megváltozik (akár hosszú, akár rövid lépést teszünk meg), ezért a páros pozícióban álló lépések pontosan azok, amelyek kezdô magassága páros paritású. Tehát $E$ hosszú lépéseinek kezdő magassága páros. Először az $x$-tengelyt átugró (hosszú) lépéseket alakítjuk át, melyek a paritásfeltétel miatt csak 2 magasságról -1 magasságra, illetve -2 magasságról 1 magasságra ugró hosszú lépések lehetnek. Világos, hogy ezek a lépéstípusok felváltva követik egymást, és $E$-t olyan részutakra osztják fel, amelyek mindig szigorúan az $x$-tengely alatt vagy fölött haladnak, és végpontjuk 1 egységgel távolabb van az $x$-tengelytól, mint a kezdôpontjuk (leszámítva az utolsó esetleg üres - részutat, ahol megegyezik a kezdő és befejező magasság). Tehát ha minden második ilyen - a 2.11. ábrán háromszögekkel jelölt - részutat tükrözünk az $x$-tengelyre, és az összes $x$-tengelyugró lépést lecseréljük egy 2 magasságról 1 magasságra lépố jelölt lépésre, akkor egy végig szigorúan az $x$-tengely fölött haladó $(0,1) \rightsquigarrow(2 n, 1)$ utat kapunk, amelyben a páros pozíciókban állhatnak hosszú lépések, illetve a 2 magasságról 1 magasságra vivô lépések között lehetnek (páros pozícióban álló) jelölt lépések is.

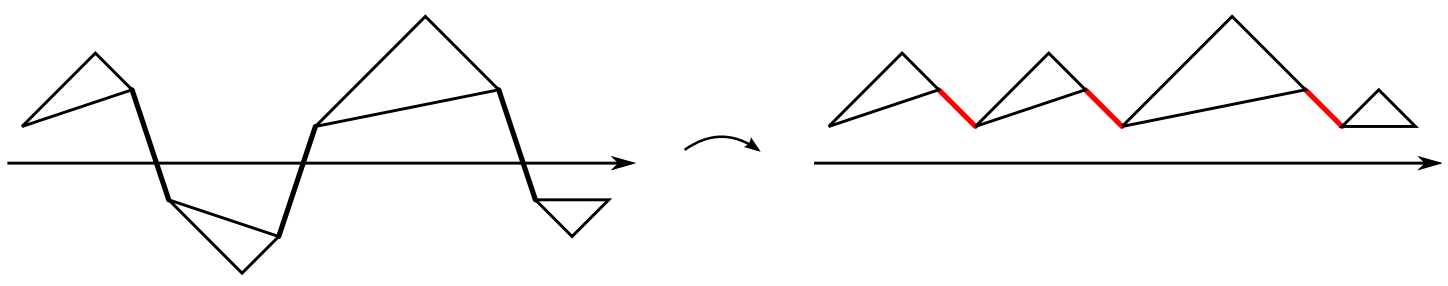

2.11. ábra: A tengelyt átugró lépések átalakítása

Ez a kódolás első fázisa, a kapott utat jelölje $E^{+}$. Annyi jelölt lépést hoztunk létre (megengedett pozíciókban), mint ahány hosszú lépést megszüntettünk, tehát eddig figyelembe vettük a $\phi$-re vonatkozó követelményt. Az elsô fázis invertálható: Minden fenti tulajdonságú $E^{+}$útra egyetlen olyan $E \in \mathcal{E}^{*}$ út létezik, amelyet az első fázis $E^{+}$-szá alakít át, ugyanis $E^{+}$jelölt lépései megadják az $x$-tengelyt átugró lépéseket, és így a köztes részutakat is, amelyekból egyértelmúen kitalálható az $\mathcal{E}^{*}$-beli inverz kép.

Mielótt rátérnénk a második, lényegi fázisra, ismertetjük $E^{+}$lépéseinek egy csoportosítását, amelyre kódolásunk során szükségünk lesz. Ezt először a Dyckutak lépéseinek csoportosításával motiváljuk. (Előrebocsátjuk, hogy ha $E^{+}$Dyck- 
út, akkor a második fázis nem végez további átalakításokat $E^{+}$-on.) Egy $2 n$ hosszú Dyck-út lépéseinek egy természetes párbaállítása a következô: Egy $s$ felfelé lépés párja legyen a lépés után következő első olyan lefelé lépés, amely visszatér $s$ kiinduló szintjére, lásd 2.12. ábra. Egyszerúen ellenôrizhetô, hogy ez jó definíció, mellyel $n$ lépéspárba soroljuk a lépéseket. (Ha a Dyck-útra „értelmes” zárójelsorozatként tekintünk a közismert módon, a felfelé lépéseket nyitó zárójelekre, a lefelé lépéseket csukó zárójelekre cserélve, akkor a kapott zárójelezésben az összetartozó nyitó és csukó zárójelek adják meg a lépések párbaállítását.) A standard Catalan-rekurzió Dyck-utakkal történő szokásos bizonyítása is ehhez a párbaállításhoz vezet.
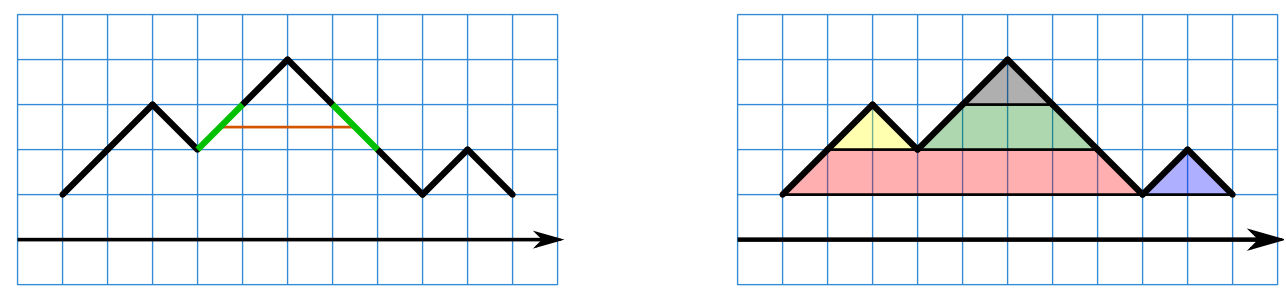

2.12. ábra: A Dyck-utak lépéseinek párbaállítása

A lépéspárokra bontást úgy is megfogalmazhatjuk, hogy két lépés akkor alkot egy párt, ha az úthoz tartozó (a 2.12. ábra bal oldalán szemléltetett) grafikonon a két lépés megfelelő belsô pontjai összeköthetôk egy vízszintes ( $x$-tengellyel párhuzamos) szakasszal úgy, hogy a szakasz végig az útnak megfelelö töröttvonal alatt haladjon, a végpontjait leszámítva. (Egy lépés belső pontján a lépésnek megfelelő grafikonszakasz egy olyan pontját értjük, amelynek magassága nem egész. Tehát hosszú lépések esetén két szokásos értelemben vett belsô pontot nem tekintünk annak a továbbiakban.) Az egy párba tartozást bizonyító szakaszok összessége minden kialakult lépéspárra egy trapézt határoz meg (amely esetleg háromszöggé fajulhat), és így a lépéspárok az út grafikonja és az $y=1$ egyenes által közrezárt tartományt trapézokra darabolják az ábra jobb oldalán látható módon. (A trapézok határvonalaival nem foglalkozunk.) A késóbbiekben is így fogjuk szemléltetni az egy osztályba sorolt lépéseket, sôt, a definícióknál és bizonyításoknál is erre a vizualizációra támaszkodunk, a megértést megkönnyítendő.

Most áttérünk az általános esetre. Tekintsünk egy tetszóleges $E^{+}$utat, amelyet az elsố fázis után megkaphattunk. A fenti speciális eset analógiájára két $E^{+}$-beli lépés álljon relációban („tartozzon egy osztályba”), ha van olyan vízszintes szakasz, amely a két lépés egy-egy belsố pontját köti össze, és végig az út grafikonja alatt halad. (Ha a két lépés egybeesik, akkor relációban állnak definíció szerint. Különbözô lépések esetén mindig egy felfelé és egy lefelé lépés áll relációban az út grafikonjának folytonossága miatt.) Ez a bináris reláció nem ekvivalenciareláció, csak szimmetrikus és reflexív; a reláció tranzitív lezártjának ekvivalencia-osztályait $E^{+}$építóelemeinek nevezzük. (Tehát az $s$ és $t$ lépések pontosan akkor tartoznak egy építóelemhez, ha van olyan $l_{1}, \ldots, l_{m}$ lépéssorozat $E^{+}$-ban, hogy $l_{1}=s$ és $l_{m}=t$, továbbá a sorozatban egymás mellett álló lépések relációban állnak.) Ha a különböző $s$ és $t$ lépések relációban állnak, azt úgy is mondjuk, hogy az $s$ lépés egy párja $t$. (Egy hosszú lépésnek több párja lehet, sôt, a paritásfeltétel miatt valójában mindig 
több párja is van.) Az építôelem szóhasználatot az motiválta, hogy az egy építôelemhez tartozó „bizonyító szakaszok” a fentiekhez hasonlóan ismét egy felosztását adják az $E^{+}$út grafikonja alatti tartománynak, ezért a 2.13. ábrán látható módon is szemléltethetjük az építőelemeket. (Világos, hogy az egész magasságú pontoktól eltekintve, az $E^{+}$grafikonja alatti tartomány tetszóleges $A$ pontján egyetlen bizonyító szakasz halad át, a vizsgált ponton átmenó egyenesból az $E^{+}$grafikonja által kimetszett, $A$-t tartalmazó szakasz. Az $E^{+}$út folytonos grafikonja nyilván metszi a szóban forgó egyenest a vizsgált $A$ pont elótt és után is, hiszen $E^{+}$két végpontja az egyenes alatt helyezkedik el, míg az $A$ abszcisszájának megfelelő ,idôpontban" $E^{+}$ az egyenes fölött halad.) Ez a szemlélet nagyban segíti a megértést a továbbiakban, a kialakult sokszögekre az építőelemekhez társított sokszögekként hivatkozunk.

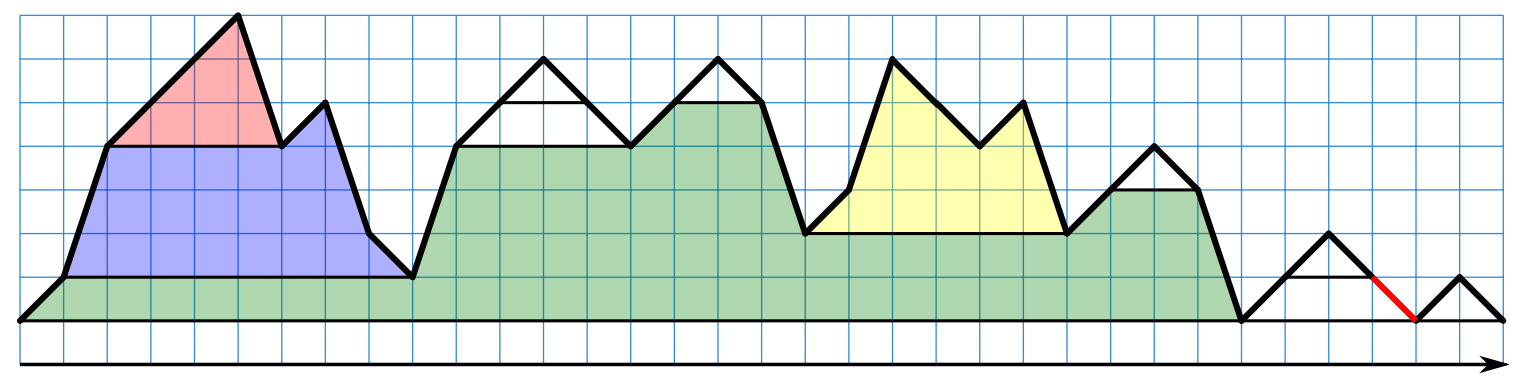

\subsection{3. ábra: Építôelemekre bontás}

Összefoglaljuk az építôelemek néhány könnyen ellenórizhetô tulajdonságát. Minden lépésnek van párja, vagyis minden építôelem legalább két lépésból áll: Egy $s$ lépés tetszóleges belsố pontjából a megfelelő irányba (felfelé lépés esetén jobbra, lefelé lépés esetén balra) indított vízszintes nyílt félegyenes elsố $E^{+}$-szal vett metszéspontját tartalmazó $\hat{s}$ lépés az $s$ párja. (A metszéspont létezik, ugyanis $E^{+}$ megfelelő végpontja alacsonyabban fekszik, mint a vizsgált belsố pont.) A továbbiakban többször fogunk még ezzel a módszerrel párt keresni, ezért a körülményes leírás megismétlése helyett a továbbiakban úgy fogalmazunk, hogy $s$ egy adott belsó pontjából $\hat{s}$-ot látjuk (mindig vízszintesen, az $E^{+}$út alatti rész felé „nézünk”, és $\hat{s}$ mindig létezik). Nyilvánvaló, hogy egy lépés párjai pontosan a lépés $h+0,5$ alakú $(h \in \mathbb{Z})$ belsố pontjaiból látható $E^{+}$-beli lépések. Így egy rövid lépésnek pontosan 1, egy hosszú lépésnek pedig 2 vagy 3 párja van; utóbbi esetben azért nem lehet pontosan 1, mert nem fordulhat elő, hogy egy hosszú $s$ felfelé lépés összes pontjából ugyanazt a hosszú $\hat{s}$ lefelé lépést látjuk, ugyanis $\hat{s}$ kezdôpontja nem lehet 3 egységgel magasabban, mint $s$ kezdôpontja, lévén a kezdôpontok magasságának paritása megegyezik (páros) $\mathcal{E}^{*}$ definíciója alapján. Emiatt a két lépésból álló építôelemek mindkét lépése rövid; ezeket az építőelemeket trapézoknak nevezzük (a 2.13. ábrán fehér színnel jelöltük óket). Most a nem trapéz építôelemeket vizsgáljuk meg. Tekintsünk egy tetszôleges ilyen $\mathfrak{E}$ építőelemet, és abban a legalacsonyabban fekvő hosszú lépést, amelyet $s_{1}$-gyel jelölünk. (Két lépés magasságának összehasonlításánál a lépéseket reprezentáló szakaszok legalacsonyabb pontjait vesszük figyelembe.) Tegyük fel, hogy ez a lépés felfelé lépés, és a kiinduló magassága $h$. Ha $s_{1}$ párjai között van hosszú (lefelé) lépés, akkor ez csak a $h+4$ magasságról indulhat $(a h+1$ 
magasságra); ugyanis a hosszú lépésekre vonatkozó paritásfeltétel miatt csak a $h+2$ kiinduló szint jöhet szóba alternatívaként, de mivel $s_{1}$ a legalacsonyabb hosszú lépés az építóelemben, így ez a kezdőszint nem fordulhat elő. Ez persze azt is jelenti, hogy $s_{1}$ párjai között legfeljebb egy hosszú lépés lehet csak; ha van ilyen, akkor jelöljük $s_{2}$-vel. Megjegyezzük, hogy $s_{2}$ biztosan látható $s_{1}$ középső harmadából, ugyanis ha más lépést látnánk innen, akkor $E^{+}$grafikonjának folytonossága miatt a felsố harmadból sem $s_{2}$-t látnánk; az alsó harmad pedig $s_{2}$ záró szintje alatt helyezkedik el. Az előzőekhez hasonlóan $s_{2}$ párjai között $s_{1}$-en túl legfeljebb egy $(h+2$ magasságról induló) hosszú felfelé lépés lehet, amelyet, ha létezik, $s_{3}$-mal jelölünk. Mivel az $s_{1}$ lépés kezdôszintje alacsonyabb, mint $s_{2}$ záró szintje, $E^{+}$grafikonjának folytonossága miatt az $s_{2}$-ból látható lépések $s_{1}$ után állnak $E^{+}$-ban (vagy megegyeznek $s_{1}$-gyel), így az $s_{3}$ lépés $s_{1}$ és $s_{2}$ között áll $E^{+}$-ban. Az építóelem hosszú lépéseinek keresését folytatjuk $s_{3}$ párjai között, és így tovább, a 2.14. ábrán nyilakkal szemléltetett toronyszerú elrendezésben kapjuk meg az $s_{1}, s_{2}, s_{3} \ldots$ hosszú lépéseket, amelyek $E^{+}$-beli sorrendje tehát $s_{1}, s_{3}, \ldots, s_{4}, s_{2}$. (Azért a hosszú lépéseket vizsgáljuk, mert ezek felelősek az építôelem „függóleges növekedéséért”.) Korábbi megjegyzésünkhöz hasonlóan $s_{i+1}$ az $s_{i}$ hosszú lépés középsố harmadából látható lépés, amennyiben az hosszú és különbözik $s_{i-1}$-tôl. Az újabb és újabb hosszú lépések megtalálása természetesen egyszer véget ér, például az $s_{m}$ lépésnek nincs új $s_{m+1}$ hosszú lépés párja. Ez azt jelenti, hogy az $s_{m}$ lépésnek megfelelő szakasz középső harmadából vagy egy rövid lépést látunk, vagy $s_{m-1}$-et, nem egy új hosszú lépés alsó harmadát. Az elsố esetben azt mondjuk, hogy a vizsgált építőelem rövid zárólépésú torony, a második esetben pedig azt, hogy hosszú zárólépésú torony, ld. rendre a 2.14. ábra bal és jobb oldalát. Természetesen $s_{1}$, a legalacsonyabb hosszú lépés $\mathfrak{E}-$ ben, lehet lefelé lépés is, ebben az esetben analóg módon járunk el; a folyamat és a kapott típusok szemléltetéséhez az ábra tornyait tükrözni kell egy függóleges tengelyre (és $s_{1}$ a jobb szélsó lépés lesz).
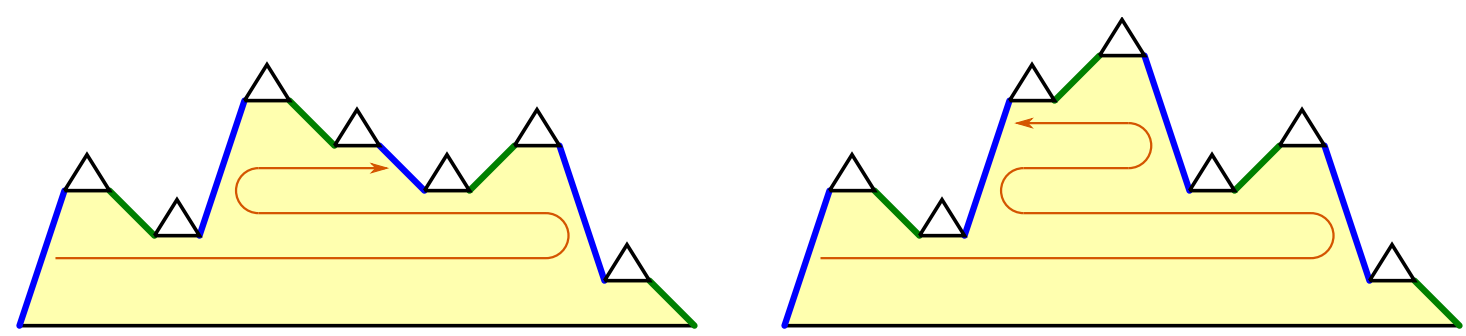

2.14. ábra: Torony építôelemek

A 2.14. ábrán a vizsgált építőelem szóban forgó lépéseit (a hosszú lépéseket és az esetleges rövid zárólépést) kék színnel jelöltük. Figyeljük meg, hogy ezek a lépések mind páros pozícióban állnak (a rövid záró lépés is). Az építőelem többi, zölddel jelölt lépése rövid lépés lesz a már végiggondoltak miatt (az $s_{i}$ lépések további párjai mind rövidek), így valóban csak az ábrán látható alakúak (illetve a tükörképeik) lehetnek a nem trapéz építôelemek (itt ismét felhasználva $E^{+}$grafikonjának folytonosságát is). Továbbá a zölddel jelölt lépések páratlan pozíciókban állnak. Az építôelem a zöld és kék lépések összessége, a társított sokszöget pedig sárga színnel 
szemléltettük; a háromszögek helyén pedig tetszóleges (akár 0 hosszú) utak állhatnak, amelyek nem mennek a kiinduló (és egyben befejezô) szintjük alá, feltéve, hogy az $E^{+}$útra kirótt tulajdonságok alapján megengedettek. A kék és zöld lépések váltakozva követik egymást balról jobbra haladva, és egy építóelem lépéseinek száma mindig páros. Például a 2.13. ábrán a piros és sárga színnel jelölt építőelemek rövid zárólépésû tornyok, a kék és zöld építőelemek pedig hosszú zárólépésû tornyok.

Most az építőelemek egymáshoz viszonyított elhelyezkedését vizsgáljuk meg. Tekintsünk egy tetszôleges $\mathfrak{E}$ építőelemet, melynek lépései az $E^{+}$útban balról jobbra haladva legyenek $t_{1}, \ldots, t_{m}$, és egy $\mathfrak{E}^{\prime}$ építóelemet, melynek lépései ebben a sorrendben $t_{1}^{\prime}, \ldots, t_{l}^{\prime}$. Azt állítjuk, az építôelemek vagy egymás mellett helyezkednek el (az egyik összes lépése megelőzi a másik összes lépését $E^{+}$-ban), vagy egymásba ágyazottak; utóbbi alatt azt értjük, hogy az egyik építóelem összes lépése a másik építőelem két (elôzố felsorolásban) szomszédos lépése között áll $E^{+}$-ban, azaz $\mathfrak{E}$ összes lépése $t_{i}^{\prime}$ után és $t_{i+1}^{\prime}$ elótt áll valamely $i$-re, vagy fordítva, $\mathfrak{E}$ és $\mathfrak{E}^{\prime}$ szerepének felcserélésével. Ezt csak torony építóelemekre gondoljuk végig (a többi eset még egyszerúbb): Ha a két építőelem nem egymás mellett helyezkedik el, akkor az egyik építôelem valamely lépése az $E^{+}$út egy olyan (a 2.14. ábrán háromszöggel jelölt) $R$ részútjához tartozik, amelyet a másik építőelem valamely két ,szomszédos" lépése határol. Az $R$ útszakasz kezdő és befejezô magassága megegyezik, mely magasság alá soha nem lép, így minden $R$-beli lépés párjai is $R$-beliek, ami pontosan azt jelenti, hogy az elsô építóelem összes lépése $R$-ben van, vagyis a két építőelem valóban egymásba ágyazott. Az egymásba ágyazottság az építőelemekhez társított sokszögek segítségével úgy is megfogalmazható, hogy $\mathfrak{E}$ és $\mathfrak{E}^{\prime}$ közül az egyiknek megfelelố sokszög valamelyik felsô (azaz nem a legalsó) vízszintes oldala felett helyezkedik el teljes egészében a másiknak megfelelő sokszög (úgy, hogy pontjainak abszcisszái a szóban forgó oldal által kijelölt intervallumban maradnak). Mivel az $E^{+}$alatti tartománynak csak az alsó, a $(0,1)$ és $(2 n, 1)$ pontokat összekötó oldala vízszintes, és az építôelemekhez társított sokszögek felbontják ezt a tartományt, ezért mindegyik ilyen sokszög ,alapoldala” (azaz vízszintes legalsó oldala) vagy további építóelem(ek)et határol, vagy része az $y=1$ egyenesnek. Az egymásba ágyazottság szerint mindegyik alapoldalnak csak egyetlen másik (alsóbb) sokszög határával lehet közös szakasza, azaz tulajdonképpen az építőelemekre bontás során az $E^{+}$út alatti tartományt trapézokból és a 2.14. ábrán sárgával színezett speciális alakú sokszögekból „LEGO-szerúen” építjük fel úgy, hogy a $(0,1)$ és $(2 n, 1)$ pontokat összekötô szakaszra és a már elhelyezett sokszögek felsố vízszintes oldalaira kerülhetnek további sokszögek mindaddig, amíg ezen „szabad” vízszintes szakaszok el nem fogynak (vö. 2.13. ábra). Az építőelemek strukturális jellemzésének zárásaként kiemeljük, hogy $E^{+}$elsô fázisban létrehozott, 2 magasságról 1 magasságra lépó jelölt lépései mindig trapéz építőelemhez tartoznak, ugyanis egy ilyen lépés párja mindig rövid, hiszen nincs 1 magasságról induló hosszú felfelé lépés $E^{+}$-ban a paritásfeltétel miatt (az 1 magasság alá pedig soha nem kerül $E^{+}$).

Ezen előkészületek után definiáljuk az $E \in \mathcal{E}^{*}$ út $\phi(E)$ képét. $E$-n először végrehajtjuk az elsô fázis átalakításait, majd az így kapott $E^{+}$utat alakítjuk tovább. (Emlékeztetôül, az $E^{+}$út egy végig szigorúan az $x$-tengely felett haladó 
$(0,1) \rightsquigarrow(2 n, 1)$ út, melyben a páros pozíciókban állhatnak hosszú lépések, illetve a legalsó szinten jelölt rövid lefelé lépések. Az ilyen tulajdonságú utak halmazát a továbbiakban $\mathcal{E}^{+}$-szal jelöljük.) $E^{+}$-t az előzôekben leírt módon építôelemekre bontjuk, és alkalmazzuk a 2.15. ábrán látható átalakítást az összes torony építőelemre (a trapéz építőelemeket változatlanul hagyjuk). Tehát a T torony építóelemet a következóképpen alakítjuk át, ha lépései balról jobbra haladva $t_{1}, \ldots, t_{2 m}$ (egy építôelem mindig páros sok lépést tartalmaz): Ha T rövid zárólépésú, és a legalacsonyabban fekvő hosszú lépése a $t_{1}$ felfelé lépés (ld. az ábra bal oldalát), akkor T lépéseit balról jobbra haladva rendre a $\nearrow, \nearrow, \searrow, \ldots, \nearrow, \searrow, \searrow$ rövid lépésekre cseréljük. (Az elsố és utolsó lépést törölve a $\nearrow, \searrow$,minta” ismétlődik $(m-1)$-szer, ahol a jelölt lépéseket pirossal írjuk.) Ha T rövid zárólépésú, és a legalacsonyabban fekvő hosszú lépése a $t_{2 m}$ lefelé lépés (ez a „tükrözött” eset), akkor a minta (és a szemléltető ábra) is tükröződik, azaz a $\nearrow, \nearrow, \searrow, \ldots, \nearrow, \searrow, \searrow$ lépéssorozatra cserélünk. Ha T hosszú zárólépésú (ld. az ábra jobb oldalát), akkor annyiban módosul a fenti konverzió, hogy az első (nem tükrözött) esetben a $t_{1}$ lépést lecserélő felfelé lépés is jelölt lesz, a második (tükrözött) esetben pedig ehelyett a $t_{2 m}$-et lecseréló lefelé lépést változtatjuk jelöltté. Ezt a konverziót $\chi$-vel jelöljük. Megjegyezzük, hogy ábráinkon a lépések kék, illetve zöld színének nincs többletjelentése, ezek csupán a lépés pozíciójának páros, illetve páratlan paritását mutatják, ezen lépések mindig jelöletlenek (a jelölt lépések továbbra is piros színúek lesznek).
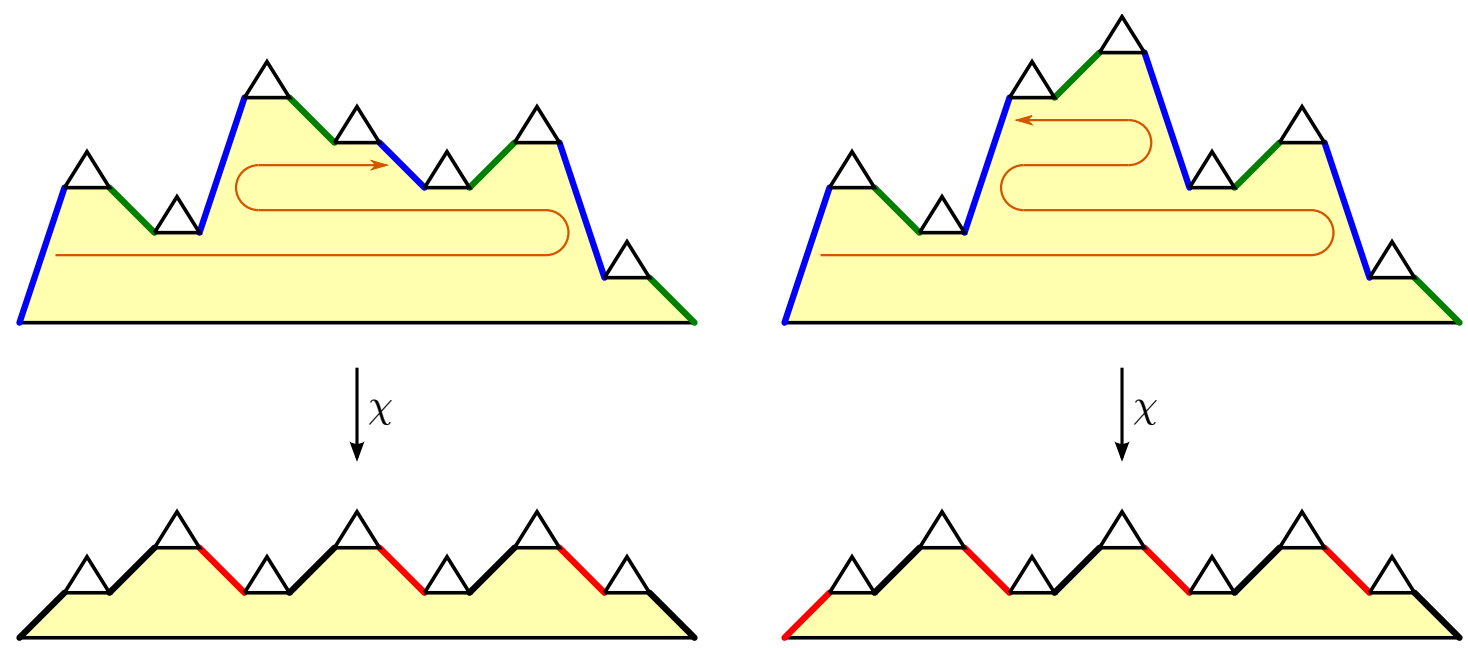

2.15. ábra: A torony építôelemek átalakítása

$\phi(E)$ legyen az átalakítások után kapott jelölt út, ld. 2.16. ábra. Ez értelmes definíció, mert $E^{+}$lépéseit osztályoztuk, és megadtuk, hogy az egyes osztályok lépéseit hogyan alakítjuk át. Akkor is ugyanehhez a $\phi(E)$ úthoz jutunk, ha a torony építôelemeket egymás után (tetszôleges sorrendben) egyesével alakítjuk át a fentiek szerint. Ez alatt azt értjük, hogy ha $E^{+}$-ban egy tetszóleges torony építóelemet átalakítunk, majd az átalakítás után kapott út egy újabb építóelemére is alkalmazzuk $\chi$-t, és így tovább, addig folytatva az eljárást, amíg el el nem fogynak a torony építőelemek (hosszú lépések), akkor végül $\phi(E)$-hez jutunk. Bizonyításként 
induljunk ki abból, hogy az $E^{+}$út alatti részt „LEGO-szerúen” felosztják az építőelemeknek megfelelő sokszögek, és egy torony építőelem konverziójára gondoljuk úgy, hogy a hozzá társított sokszöget lecseréljük a 2.15. ábra megfelelô alsó sárga sokszögére. Egy ilyen építóelem-konverzió (sokszögkonverzió) nem változtatja meg a többi építőelemet (sokszöget), ez az egymásba ágyazottságból (a „LEGO-szerû” elrendezésból) könnyen látszik: Egy építốelem átalakítása során csak annyi történik, hogy a 2.15. ábrán háromszögekkel jelölt útszakaszok (a sokszög felsô oldalai), és így a háromszögekkel jelölt útszakaszok építőelemei (az ezen oldalakra „pakolt” további sokszögek) eltolódnak függólegesen (és az épp átalakított torony szétesik trapéz építôelemekre). Itt kimondatlanul felhasználtuk azt is, hogy a $\chi$ konverzió változatlanul hagyja a sárga sokszög vízszintes alapoldalát - tehát a háromszöggel jelölt útszakaszokat nem toljuk ezen szint alá -, így az alsóbb építóelemek sem módosulnak. Ez azt jelenti, hogy egy $E^{+}$-beli $\mathfrak{E}$ torony építőelemre néhány más építőelem átalakítása után is végrehajthatjuk $\chi$-t, mert $\mathfrak{E}$ még akkor is építőelem lesz, és lépéseinek pozíciói megegyeznek az eredeti pozíciójukkal (csak más lépések változtatása miatt esetleg függólegesen eltolva jelennek meg az út grafikonjában), így lépései pontosan a $\phi$ definíciójában előírt módon változnak. Egy T torony építőelemhez tartozó eredeti és átalakított sokszögek egymásba ágyazottság szempontjából ekvivalensek, mivel vízszintes oldalaik ( $x$-tengelyre eső vetületei) megegyeznek, így valójában azt is végiggondoltuk, hogy az átalakított sokszögeket sem változtatja meg a további építóelemek késóbbi átalakítása, ezek a folyamat legvégéig megmaradnak, megórizve a ferde oldalaknak megfelelő (bizonyos építőelem átalakításával nyert) lépések egymáshoz viszonyított helyzetét a végső $\phi(E)$ út grafikonjában is. Az elmondottakat is szemlélteti a 2.16. ábra.
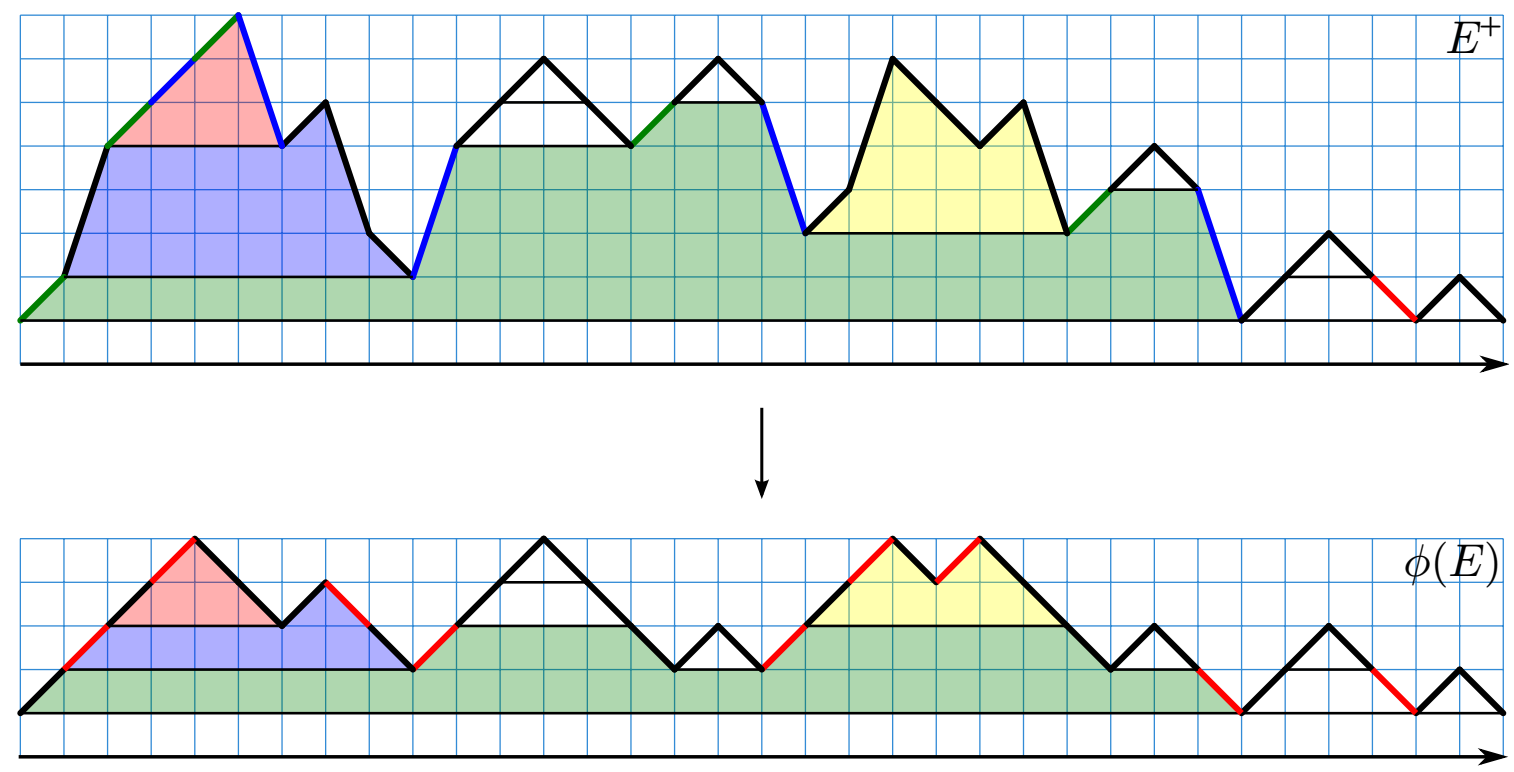

2.16. ábra: A második fázis illusztrációja

Most igazoljuk, hogy $\phi$ egy megfelelő bijekció. $\phi(E)$ egy végig szigorúan az $x$-tengely felett haladó $(0,1) \rightsquigarrow(2 n, 1)$ út, hiszen $E^{+}$is ilyen, és világos, hogy 
egy torony építóelem átalakításával az út két végpontja, valamint az út minimális magassága változatlan marad. $E^{+}$összes hosszú lépését rövid lépésre cseréltük $\phi(E)$-ben, ugyanis minden hosszú lépés egy torony építôelem része, és egy építôelem átalakításakor annak összes lépését rövidre cseréli $\chi$. Az eddigieket egybevetve azt kaptuk, hogy a lépések jelöltségétól eltekintve $\phi(E)$ egy $2 n$ hosszú Dyck-út (1 egységgel felfelé tolva). Mivel $E^{+}$( $E$ tengelyugró lépéseit kódoló) jelölt lépései páros pozíciókban álltak, illetve jelölt lépéseket mindig páros pozíciókban hoztunk létre az átalakítások során (vö. 2.15. ábra), ezért $\phi(E) \in \mathcal{D}_{2}$. Az is teljesül, hogy $\phi(E)$ ben ugyanannyi jelölt lépés van, mint ahány hosszú lépés $E$-ben: Az elsô fázis ( $x$-tengelyugró) hosszú lépéseket alakított át jelölt lépésekké, a második fázisban pedig minden torony építőelem átalakítása során az építőelem lépéseit lecserélő lépések között ugyanannyi jelölt lépést hoztunk létre, mint ahány hosszú lépés volt az építóelemben. Itt felhasználtuk azt is, hogy $E^{+}$kiinduló jelölt lépései trapéz építóelemekhez tartoznak, ezért a 2.15. ábra bal oldalán látható torony építóelem rövid (záró)lépése jelöletlen. Ezzel beláttuk, hogy $\phi$ egy $\mathcal{E}^{*} \rightarrow \mathcal{D}_{2}$ függvény, amely teljesíti a rá kiszabott számosságfeltételt. Már csak azt kell igazolni, hogy $\phi$ bijekció. Ehhez vegyünk egy tetszóleges $F \in \mathcal{D}_{2}$ utat, például a 2.16. ábra alsó útját, és határozzuk meg az összes olyan $E \in \mathcal{E}^{*}$ utat, amelyre $\phi(E)=F$. Kódolásunk elsố fázisa nyilvánvalóan bijekciót létesít $\mathcal{E}^{*}$ és $\mathcal{E}^{+}$között, így valójában az összes olyan $E^{+} \in \mathcal{E}^{+}$utat keressük, amelyet a második fázis $F$-fé alakít. Láttuk, hogy egy $E^{+}$utat úgy alakít át a második fázis, hogy a torony építőelemeknek megfelelő sokszöget a $\chi$ konverzió szerint átalakítjuk, majd a kapott sokszögeket (és a változatlanul hagyott trapézokat) megfelelő függóleges eltolásokkal összeillesztjük az $y=1$ egyenesre ,építkezve” (ez megvalósítható), és a kapott tartomány határvonala (a vízszintes alsó szakasztól eltekintve) megadja az átalakítás után kapott utat. A továbbiakban $\chi$-sokszögeknek nevezzük azokat a sokszögeket, amelyeket megkaphatunk valamely torony építőelemhez tartozó sokszögból a $\chi$ átalakítással, továbbá a sokszög ferde oldalai jelöltek vagy jelöletlenek az átalakítási szabálynak megfelelốn (ld. a 2.15. ábra alsó részét). A második fázis végén tehát az $E^{+}$-ból kapott utat az út alatti tartomány sokszögekre bontásával együtt kapjuk meg, ahol minden sokszög $\chi$-sokszög vagy trapéz, és bizonyos legalsó szinten álló trapézokat leszámítva a trapézok szárai jelöletlen lépéseknek felelnek meg. Az ilyen tulajdonságú sokszögekre bontást röviden csak $\chi$-sokszögekre bontásnak nevezzük. Az $F$ út alatti tartomány minden $\mathcal{S} \chi$-sokszögekre bontásához pontosan egy olyan $E^{+} \in \mathcal{E}^{+}$-beli út található, amelyból a második fázis $F$-et készít, méghozzá az $\mathcal{S}$ felbontásból „felépítve". Ez az $E^{+}$út csak az az út lehet, amelyet úgy kapunk, hogy $\mathcal{S} \chi$-sokszögeire alkalmazzuk a $\chi$ átalakítás inverzét (az invertálhatóság világos), a trapézokat változatlanul hagyjuk, és a kapott sokszögekből a szokásos módon függóleges eltolások után felépítjük $E^{+}$-t. A második fázis elemzéséhez hasonlóan végiggondolható, hogy ez értelmes definíció, és az is könnyen látszik, hogy a kapott $E^{+}$út $\mathcal{E}^{+}$-beli, lévén az $F$-beli jelölt lépések páros pozícióban álltak (és így az $E^{+}$-beli hosszú lépések páros is pozícióban állnak), illetve $\mathcal{S}$ trapézaira olyan feltételeket szabtunk, hogy csak a legalsó szinten lehetnek jelölt lépések $E^{+}$-ben (páros pozíciókban). Az pedig világos, hogy ez az $E^{+}$út megfelelő lesz, így állításunkat igazoltuk. 
Most már csak azt kell belátni $\phi$ bijektivitásához, hogy minden $F \in \mathcal{D}_{2}$ jelölt Dyck-útra az $F$ grafikonja alatti tartománynak pontosan egy $\chi$-sokszögekre bontása van. Ez „felülról lefelé haladva” igazolható, amelyet egy konkrét példán keresztül mutatunk be. Legyen $F$ a 2.16. ábra alsó útja. Végiggondoljuk, hogy csak az ábrán látható $\chi$-sokszögekre bontás létezik $F$-hez. (És így $\phi^{-1}(F)$ az az út lesz, amelyet az ábra felsô útjából nyerünk úgy, hogy a jelölt lépését lecseréljük egy hosszú lefelé lépésre, és a két hátralévô lépést tükrözzük az $x$-tengelyre.) Bizonyos legalsó szinten álló jelölt lépéseket leszámítva, mindegyik jelölt lépés egy $\chi$-sokszög oldala $F$ tetszóleges $\chi$-sokszögekre bontásában. A felbontás unicitása elsô ránézésre nem triviális, mert egy jelölt lépés tartozhat egy $\chi$-sokszög alsó szintjéhez, illetve egy másik $\chi$-sokszög felsố szintjéhez is. (Minden $\chi$-sokszög egy „alsó szinten” álló trapéz és az erre helyezett „felsố szinten álló” további trapézok egyesítése.) Ezért haladunk felülről lefelé. Az $F$ út legmagasabban elhelyezkedô jelölt lépései nyilvánvalóan csak az óket tartalmazó $\chi$-sokszögek felsố szintjén állhatnak, és egy ilyen lépés trapéz építôeleme megadja a lépést tartalmazó $\chi$-sokszög egyik felső szinten álló trapézát, valamint tudjuk, hogy az ezen trapéz alatt álló trapéz építóelem lesz a $\chi$-sokszög alsó szintje. Ezáltal egyértelmúen meghatározható az összes olyan $\chi$-sokszög a keresett felbontásban, amelynek van lépése (ferde oldala) $F$ grafikonjának legmagasabb szintjén. (Egy $\chi$-sokszög felsô szintjén ugyanis mindegyik trapéz megfelelő paritású lépése jelölt, így $F$ legmagasabb szintjén a két jelöletlen lépésből álló trapézok biztosan nem tartoznak $\chi$-sokszög felsô szintjéhez.) A konkrét példában 3 legmagasabb jelölt lépés van, ezek egyértelmúen kijelölik az óket tartalmazó piros és sárga $\chi$-sokszögeket, és azáltal azt is, hogy $F$ eggyel alacsonyabb szintjén pontosan mely trapéz építőelemek alkotják ezek közül valamely $\chi$-sokszög alsó szintjét. A második legmagasabb szinten tehát minden jelölt lépésról tudjuk, hogy egy, a legmagasabb szinten „kezdődô” $\chi$-sokszög alsó szintjéhez, vagy egy, a második legmagasabb szinten „kezdődô” $\chi$-sokszög felsô szintjéhez tartozik-e. Utóbbi esetekben a felsố szinthez hasonló módon egyértelmûen meg tudjuk határozni a második szinten kezdődő $\chi$-sokszögeket, példánkban az egyetlen második legmagasabb jelölt lépés kijelöli a kék $\chi$-sokszöget. És így tovább, szintrôl szintre haladva lefelé $F$-ben, mindig meg tudjuk határozni az adott szinten kezdődő $\chi$-sokszögeket egyértelmúen, példánkban a második szint 3 jelölt lépése közül az elsőról már tudjuk, hogy a kék $\chi$-sokszöghöz tartozik, a másik két lépés pedig kijelöli a zöld $\chi$-sokszöget. A folyamat akkor áll meg, amikor elértük $F$ legalacsonyabb szintjét, ahol maradhatnak a második legalacsonyabb szinten kezdôdő $\chi$-sokszögek által nem tartalmazott jelölt lépések (lefelé lépések a 2 magasságról az 1 magasságra). Mivel egyértelmúen meghatároztuk az összes $\chi$-sokszöget, a $\chi$-sokszögekhez nem rendelt lépések (trapéz építőelemek) csak a $\chi$-sokszögekre bontás trapézai lehetnek, amelyekre eljárásunk miatt teljesül, hogy csak a legalsó szinten állóknak lehet jelölt oldala. Ezzel a $\chi$ sokszögekre bontás egyértelműségét beláttuk. A felbontás létezése könnyen adódik az $F$ út grafikonjának folytonosságából („diszjunkt” $\chi$-sokszögeket kapunk), a trapéz építóelemek nyilvánvaló egymásba ágyazottságából (van értelme arról beszélni, hogy egy trapéz építőelem alatti trapéz építőelem), illetve abból a tényből, hogy a jelölt lépések páros pozícióban állnak (a kapott $\chi$-sokszögek ferde oldalai úgy van- 
nak megjelölve, ahogy szükséges). Ezzel a 2.10. Lemma - és így a Shapiro-azonosság - bijektív bizonyítása véget ért.

Megjegyzés. A 2.10. Lemma kimondása után megmutattuk, hogy a lemmabeli $\phi: \mathcal{E}^{*} \rightarrow \mathcal{D}_{2}$ bijekció hogyan terjeszthetố ki egy, a 2.9. Lemmát bizonyító $\mathcal{E}_{3}^{*} \rightarrow \mathcal{D}_{4}$ bijekcióvá. Természetesebb kiterjesztést kapunk, ha az $\mathcal{E}_{3}^{*}$-beli utak címkéinek balról jobbra haladó másolása helyett figyelembe vesszük $\phi$ konstrukcióját, és egy $Q \in \mathcal{E}_{3}^{*}$ út $\mathcal{D}_{4}$-beli képét úgy definiáljuk, hogy a $Q$ 3-címkézett útra végrehajtjuk a 2.10. Lemma bizonyításában bemutatott konstrukciót (mintha címkézetlen lenne $Q$ ), és a páros pozícióban álló rövid lépések „mozgatásával” együtt mozgatjuk a címkéiket is. Azaz az elsô fázisban a címkézett rövid lépések megtartják címkéjüket, akár tükrözzük óket, akár nem; a második fázisban ha a kapott útban egy címkézett rövid lépés trapéz építőelem része, akkor a lépéssel együtt a címkéje is változatlanul marad, a rövid zárólépésû tornyok (záró)lépéseinek címkéi pedig rendre átkerülnek a torony építóelemból a $\chi$ konverzió végrehajtása után kapott lépéssorozat egyetlen páros pozícióban álló jelöletlen lépésére (amely mindig a torony lépéseiból kialakult konfiguráció alsó szintjén álló valamelyik ,szélsô” lépés, ld. a 2.15. ábra bal oldalát), és ezzel felsoroltuk az összes lehetséges esetet. A jelölt lépéseket természetesen most is 0 címkeként értelmezve, az átalakítások után kapott $\mathcal{D}_{4}$-beli utat rendeljük $Q$ hoz. Könnyen ellenőrizhető, hogy így egy $\mathcal{E}_{3}^{*} \rightarrow \mathcal{D}_{4}$ bijekciót kapunk. $\diamond$

Az alábbiakban a fenti bizonyítás néhány egyszerú következményét foglaljuk össze, köztük a Catalan-számok egy új interpretációjával.

2.11. Következmény. Jelölje $\mathcal{E}^{*}(n)$ azon $(0,1) \rightsquigarrow(2 n, \pm 1)$ (címkézetlen) utak halmazát, amelyek soha nem lépnek az x-tengelyre, és a páros pozíciókban állhatnak hosszú lépések is. (Ez a korábbi $\mathcal{E}^{*}$ halmaz, csak megjelenítjük n-et a jelölésben.)

a) $A z \mathcal{E}^{*}(n)$-beli utak száma $2^{n} C_{n}$.

b) Azon $\mathcal{E}^{*}(n)$-beli utak száma, amelyekben $k$ hosszú lépés van, $\left(\begin{array}{l}n \\ k\end{array}\right) C_{n}$.

c) Speciálisan, azon $\mathcal{E}^{*}(n)$-beli utak száma, amelyekben $n$ hosszú lépés van (tehát váltakozva követik egymást rövid és hosszú lépések), $C_{n}$.

d) $n \geq 1$ esetén a $C_{n}$ Catalan-szám megszámolja azon $(0,0) \rightsquigarrow(n, 1)$ utakat, amelyek megengedett lépései $(1, \pm 1)$ és $(1, \pm 2)$, továbbá a kezdópontot leszámítva soha nem lépnek az $x$-tengelyre.

Bizonyítás. Az a-b) állítás a 2.10. Lemma azonnali következménye, felhasználva, hogy a $2 n$ hosszú jelölt Dyck-utak száma nyilvánvalóan $2^{n} C_{n}$, illetve hogy közülük $\left(\begin{array}{l}n \\ k\end{array}\right) C_{n}$ útnak van pontosan $k$ jelölt lépése. A c) állítás pedig a b) speciális esete.

A d) állítás a c) átfogalmazása. Egy hosszú és egy rövid lépésból álló rendezett pár egyértelmúen megadható a két lépés (mint vektor) összegével, mely $(2, \pm 2)$ vagy $(2, \pm 4)$ lehet. Tehát ha töröljük a c)-beli utak kezdô felfelé lépését, majd az utakhoz hozzáveszünk egy utolsó, $x$-tengelyre lépő lefelé lépést, és a kapott $2 n$ hosszú út $n$ darab hosszú-rövid lépéspárját az összegükkel helyettesítjük, akkor 1/2-es skálázás és függóleges tengelyre való tükrözés után (bijektív módon) megkapjuk a d)-beli utakat a c)-beliekből. Ez egyszerúen ellenórizhetô. Így a két pontban szereplő utak száma megegyezik. Ezzel a d) állítást is beláttuk. 
Zárásként a 2.7.b Lemma - és így a Shapiro-azonosság (2.4) ekvivalens alakjának - bijektív bizonyításával foglalkozunk, azaz az origóból induló, $4 n$ hosszú párosmetszố utakat szeretnénk megszámolni bijektív érveléssel. Láttuk, hogy ez a feladat ekvivalens a 2.7.a Lemmabeli állítással (a 2.5. Következmény és a 2.6. Lemma szerint), melyet ebben az fejezetben már igazoltunk bijektív gondolatmenettel. Ezen ekvivalencia elmondható úgy is, hogy a 2.7.a Lemmabeli utak halmazát $\mathcal{P}$-vel, a bizonyításául szolgáló bijekció érkezési halmazát $\mathcal{R}$-rel jelölve $\left(|\mathcal{R}|=4^{n} C_{n}\right)$, a 2.7.b Lemmabeli utak halmaza és a $\mathcal{P} \times\{1, \ldots, n+1\}$ halmaz között bijekciót adunk meg, valamint bijektíven igazolható az is, hogy $|\mathcal{R} \times\{1, \ldots, n+1\}|=4^{n} B_{n}$. (A részleteket mellózzük.) Ez azt jelenti, hogy a 2.7.a Lemmát bizonyító $\mathcal{P} \rightarrow \mathcal{R}$ bijekció kiterjeszthetô a 2.7.b Lemmát bizonyító bijekcióvá. (A fordított irányú visszavezetés nem múködik automatikusan, így az utóbbi lemma a ,gyengébb” állítás a bijektív kombinatorika szemszögéból.) Amiért mégis vázoljuk a 2.7.b Lemma bijektív bizonyítását, az az, hogy egy, a 2.11. Következményhez hasonló állítás nyerhető belóle.

A bizonyítás a 2.7.a Lemma bizonyításával analóg. Hasonlóan a 2.8. Lemmában megfogalmazott célkitúzéshez, könnyư látni, hogy elég azt igazolni, hogy az $(1,1)$ pontból induló, $4 n$ hosszú páros-metszô utak száma $4^{n} B_{n}$. A korábban alkalmazott tömörítési eljárást végrehajtva a megszámolandó utakra, a következô, 2.9. Lemmával analóg feladathoz jutunk: Azon $(0,1)$ pontból induló, $2 n$ hosszú utak száma, amelyekben minden párosadik lépés vagy hosszú lépés, vagy 3-címkézett rövid lépés, és soha nem lépnek az $x$-tengelyre, $4^{n} B_{n}$. Elegendő az ezen tulajdonságú utakból a címkék elhagyásával nyert utak $\mathcal{E}^{\prime}$ halmaza és a $2 n$ hosszú jelölt nemnegatív utak $\mathcal{N}_{2}$ halmaza között olyan bijekciót megadni, amely egy $E^{\prime} \in \mathcal{E}^{\prime}$ beli úthoz mindig olyan $\mathcal{N}_{2}$-beli utat rendel, hogy abban a jelölt lépések száma megegyezik az $E^{\prime}$ út hosszú lépéseinek számával, a 2.10. Lemma mintájára. (A nemnegatív utak definíciója a 8. oldalon olvasható. A $2 n$ hosszú nemnegatív utak száma $B_{n}$ a 2.2. Állítás szerint. A jelölt Dyck-utakhoz hasonlóan most is csak páros pozíciókban álló jelölt lépések megengedettek.) A keresett $\mathcal{E}^{\prime} \rightarrow \mathcal{N}_{2}$ bijekció megadása a 2.10. Lemma bizonyításához hasonlóan történhet. Egy $E^{\prime} \in \mathcal{E}^{\prime}$ út képének meghatározása az $x$-tengelyugró hosszú lépések „lerövidítésével” és jelöltté tételével (valamint a szükséges tükrözések végrehajtásával) kezdôdik. Így egy végig szigorúan az $x$-tengely felett haladó utat kapunk, amelyet építóelemekre bontunk a második fázisban. A már megismert trapéz és torony építőelemeken felül újfajta építôelemek is megjelennek, mivel lehetnek olyan (felfelé) lépések $E^{\prime}$-ben, amelyek valamely belsố pontjából nem látunk másik lépést (mert a pontból jobbra indított vízszintes félegyenes nem metszi $E^{\prime}$ grafikonját). A $\chi$ átalakításhoz hasonló konverziót végrehajtva az építőelemeken (a trapéz és torony építóelemeket ugyanúgy alakítjuk át, mint korábban, az új építôelemeket pedig a 2.17. és 2.18. ábrákon látható módon), egy alkalmas $\phi^{\prime}: \mathcal{E}^{\prime} \rightarrow \mathcal{N}_{2}$ bijekcióhoz jutunk. (A jelölt nemnegatív utat a megszokott ábrázoláshoz képest 1 egységgel felfelé tolva kapjuk meg.) A részletek kidolgozását az olvasóra bízzuk.

2.12. Következmény. Jelölje $\mathcal{E}^{\prime}(n)$ azon $(0,1)$-ból induló, $2 n$ hosszú (címkézetlen) 
utak halmazát, amelyek soha nem lépnek az x-tengelyre, és a páros pozíciókban állhatnak hosszú lépések is.

a) $A z \mathcal{E}^{\prime}(n)$-beli utak száma $2^{n} B_{n}$.

b) Azon $\mathcal{E}^{\prime}(n)$-beli utak száma, amelyekben $k$ hosszú lépés van, $\left(\begin{array}{l}n \\ k\end{array}\right) B_{n}$.
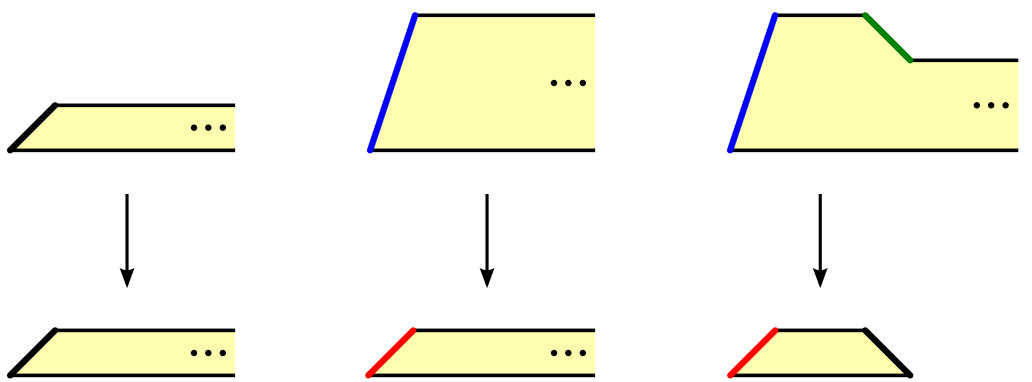

2.17. ábra: A ,végtelen" trapéz építôelemek átalakítása
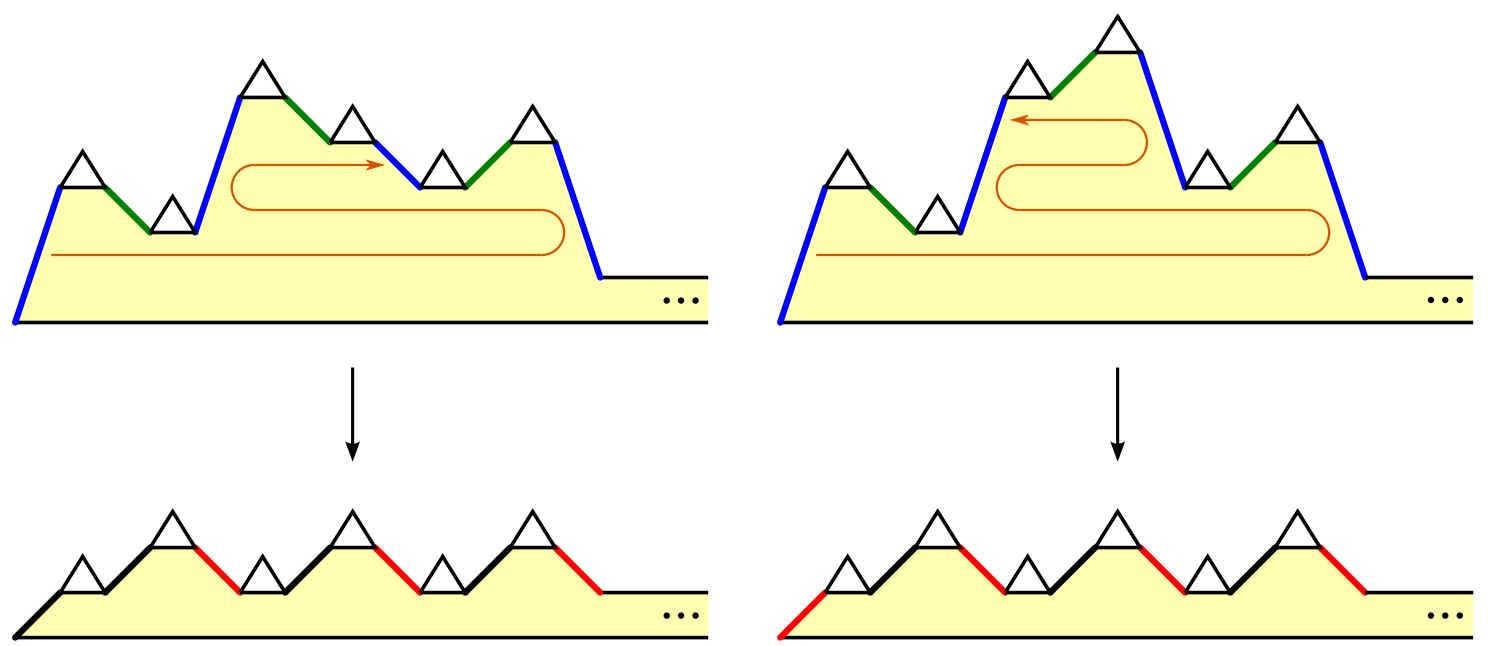

2.18. ábra: A ,végtelen" torony építôelemek átalakítása

\subsection{Alkalmazások}

Ebben az alfejezetben a kidolgozott technikák néhány alkalmazását mutatom be. Áttekintjük a $B_{n}$ és $C_{n}$ számok különbözố konvolúciós formuláit, illetve azok páros indexú változatait, kombinatorikus bizonyításokkal együtt. (Generátorfüggvényekkel egyik állítást sem nehéz belátni.) Végül kombinatorikus módon megmutatjuk a Shapiro-azonosság és a középső binomiális együtthatók alternáló konvolúciós formulájának ekvivalenciáját, illetve ismertetjük az utóbbi formula egy szép, Spiveytól származó friss bizonyítását [28], mely véletlen színezett permutációk segítségével érvel. A nem hivatkozott (és nem is nyilvánvaló) eredményeket a [16] cikkben publikáltam. Innentôl kezdve csak hagyományos, azaz $(1, \pm 1)$ lépésekból álló utakkal foglalkozunk a fejezetben.

A következó állításban a $B_{n}=\left(\begin{array}{c}2 n \\ n\end{array}\right)$ és $C_{n}=\frac{1}{n+1}\left(\begin{array}{c}2 n \\ n\end{array}\right)$ számokra vonatkozó standard konvolúciós formulákat foglaljuk össze (ezek mindegyike ismert, vö. [6]): 


\subsection{3. Állítás.}

a)

$$
\begin{aligned}
& \sum_{k=0}^{n} C_{k} C_{n-k}=C_{n+1} . \\
& \sum_{k=0}^{n} C_{k} B_{n-k}=\frac{1}{2} B_{n+1} . \\
& \sum_{k=0}^{n} B_{k} B_{n-k}=4^{n} .
\end{aligned}
$$

Bizonyítás. a) Csak a közismert (2.1) Catalan-rekurziót ismételtük meg.

b) A formula a felfelé lépéssel kezdődő $2 n+2$ hosszú kiegyensúlyozott utakat számolja össze. Ezek száma nyilván a jobb oldal, vö. 2.2.a Állítás. A bal oldal az elsố nem-origó $x$-tengelymetszet szerint csoportosítja a megszámolandó utakat: $C_{k} B_{n-k}$ olyan $2 n+2$ hosszú kiegyensúlyozott út van, amelyre az elsố nem-origó $x$-tengelymetszet a $2 k+2$ pont (csak ilyen alakú lehet valamely $k \in\{0, \ldots, n\}$-re), mert $C_{k}$-féle módon lehet a kezdó felfelé lépés után Dyck-útként eljutni az $(1,1)$ pontból a $(2 k+1,1)$ pontba, majd ezután lefelé lépés következik, és egy tetszóleges $2 n-2 k$ hosszú kiegyensúlyozott út, mely megválasztására $B_{n-k}$ lehetôség van.

c) A folklór kombinatorikus bizonyítás szerint a formula a $2 n$ hosszú utakat számolja meg (számuk nyilván $2^{2 n}$, a jobb oldal), ahol a bal oldal az utolsó $x$-tengelymetszet aszerint csoportosítja az utakat: $B_{k} B_{n-k}$ olyan $2 n$ hosszú út van, melynek utolsó $x$-tengelymetszete $2 k$, ugyanis addig a pontig $B_{k}$-féleképpen juthatunk el (2.2.a Állítás), és onnantól $B_{n-k}$-féleképpen folytatódhat az út $2 n-2 k$ hosszú seholsem-zéró útként (2.2.c Állítás).

Megjegyzés. Bár a középső binomiális együtthatók (2.5) konvolúciós formulájára adott kombinatorikus bizonyításunk az eddigiek után természetesnek tûnhet, korántsem magától értetôdő, hogy utakkal célszerû dolgozni, Stanley Bijective Proof Problems feladatsorában a „nehéz” besorolást kapta az azonosság. Formális hatványsorokkal szinte triviális igazolni, meglepó módon azonban a kombinatorikus bizonyítások közül az imént ismertetett a legegyszerúbb. Erdős Veress Pálnak és Hajós Györgynek tulajdonította a formulát, Marta Sved [33] összefoglaló cikkében további részleteket olvashatunk a hátteréról. $\diamond$

A fenti állítás alapján a standard konvolúciós formulák kombinatorikus bizonyítása egyszerú vagy ismert. A következő (bijektíven bizonyított) lemma segítségével ezekben a formulákban a páratlan indexú középső binomiális együtthatók „lecserélhetők" páros indexű Catalan-számokra és középső binomiális együtthatókra, ily módon közelebb kerülhetünk a Shapiro-azonossághoz hasonló, páros indexú számokra vonatkozó formulák kombinatorikus megértéséhez. A lemmában az indexek szimmetrikus szerepét jobban kifejezô $\sum$ jelöléseket használunk az egyszerúbb leírás kedvéért; a $\sum$-jel alatti feltételben a rögzített változó jellemzôen az egyenlóségjel jobb oldalán áll (de ez mindig kiderül a szövegkörnyezetből), továbbá a futó indexek nemnegatív egész értékeket vehetnek fel. 
2.14. Lemma. Tetszóleges rögzített $n$ esetén

$$
2 \cdot \sum_{i+j+k=n} C_{2 i} C_{2 j} B_{2 k}=B_{2 n+1}
$$

Bizonyítás. Mindkét oldal a $2 n+1$ félhosszú kiegyensúlyozott utakat számolja meg. A jobb oldalra ez világos.

$\mathrm{Az} x$-tengely minden kiegyensúlyozott utat (hagyományos vagy tükrözött) Dyck-utakra vág szét, amelyek a kezdô- és végpontjukat leszámítva nem lépnek rá az $x$-tengelyre. (Ezekre a szegmens elnevezést használjuk.) Ha a kiegyensúlyozott út félhossza $2 n+1$, akkor ezen szegmensek között lesz páratlan félhosszú, hiszen félhosszaik összege $2 n+1$, páratlan. A bal oldalon $2 C_{2 i} C_{2 j} B_{2 k}$ azokat a $2 n+1$ félhosszú kiegyensúlyozott utakat számolja meg, melyekre az $x$-tengely által levágott szegmensek közül az elsố páratlan félhosszú szegmens félhossza $2 j+1$, és ezt a szegmenst egy $2 i$ félhosszú kiegyensúlyozott út elôzi meg összességében, valamint egy $2 k$ félhosszú kiegyensúlyozott út követi $(i+j+k=n)$. Ez könnyen meggondolható: A szóban forgó szegmens megválasztására $2 C_{2 j}$ lehetôség van (hiszen ez a szegmens egy $\nearrow D \searrow$ alakú út, tükrözve vagy anélkül, ahol $D$ egy tetszóleges $2 j$ félhosszú Dyck-út lehet); a szegmenst megelőző $2 i$ félhosszú páros-metsző kiegyensúlyozott út megválasztására $C_{2 i}$ lehetôség van a 2.4. Lemma szerint (a páros-metszố tulajdonság annak átfogalmazása, hogy a korábbi szegmensek mind páros félhosszúak); a befejező $2 k$ félhosszú kiegyensúlyozott útra nincs megkötés, így az $B_{2 k}$-féle lehet. Mivel az összegzés az összes lehetőségen végigfut, a bal oldal is valóban a $2 n+1$ félhosszú kiegyensúlyozott utakat számolja meg.

Egy alkalmazásként megmutatjuk, hogy Shapiro azonosságának (2.4) ekvivalens alakja hogyan bizonyítható a lemma segítségével rekurzív módon. Belátjuk, hogy mindkét oldal kielégíti a következô rekurziót (következésképp a két oldal minden $n$-re egyenlö).

$$
\begin{aligned}
X_{0} & =1 ; \\
\sum_{s+t=n} X_{s} X_{t} & =16^{n} .
\end{aligned}
$$

A jobb oldalra ez azonnal következik a középsô binomiális együtthatók konvolúciójának (2.5) zárt alakjából:

$$
\sum_{s+t=n} 4^{s} B_{s} \cdot 4^{t} B_{t}=4^{n} \cdot \sum_{s+t=n} B_{s} B_{t}=4^{n} \cdot 4^{n}=16^{n}
$$

A bal oldalra pedig a következô számolás mutatja (2.6), valamint (2.5) ismételt 
felhasználásával:

$$
\begin{aligned}
& \sum_{s+t=n}\left(\sum_{i+k=s} C_{2 i} B_{2 k}\right)\left(\sum_{j+l=t} C_{2 j} B_{2 l}\right)=\sum_{i+j+k+l=n} C_{2 i} C_{2 j} B_{2 k} B_{2 l} \\
& =\sum_{m+l=n}\left(\sum_{i+j+k=m} C_{2 i} C_{2 j} B_{2 k}\right) B_{2 l}=\frac{1}{2} \cdot \sum_{m+l=n} B_{2 m+1} B_{2 l} \\
& =\frac{1}{2} \cdot \frac{1}{2} \cdot\left(\sum_{u+v=2 n+1} B_{u} B_{v}\right)=\frac{1}{4} \cdot 4^{2 n+1}=16^{n} .
\end{aligned}
$$

A 2.13. Állításban szereplô konvolúciók páros indexú számokra vonatkozó változatait tárgyalja a következô tétel:

\subsection{Tétel.}

a)

$$
\sum_{k=0}^{n} C_{2 k} C_{2 n-2 k}=4^{n} C_{n}
$$

b)

$$
\sum_{k=0}^{n} C_{2 k} B_{2 n-2 k}=4^{n} B_{n} .
$$

c)

$$
\sum_{k=0}^{n} B_{2 k} B_{2 n-2 k}=\frac{16^{n}+4^{n} B_{n}}{2} .
$$

Bizonyítás. a-b) Csak a (2.2) Shapiro-azonosságot és (2.4) ekvivalens alakját ismételtük meg.

c) Mivel a $B_{n}$ számok (2.5) konvolúciós formulája szerint

$$
\sum_{k=0}^{n} B_{2 k} B_{2 n-2 k}+\sum_{k=0}^{n-1} B_{2 k+1} B_{2 n-2 k-1}=16^{n},
$$

az állítás ekvivalens a középsó binomiális együtthatók (2.10) alternáló konvolúciós formulájával, melyet fontossága miatt a következő tételben külön tárgyalunk.

Az alábbi formulát Spivey bizonyította elôször kombinatorikusan 2002-ben [28]; tetszetôs érvelésében a két oldalt véletlen színezett permutációkra vonatkozó valószínúségekként értelmezi (megfelelô normálás után). Mi más utat követünk; a problémát bijektív módon visszavezetjük a már (bijektíven) bizonyított (2.8) „,vegyes" konvolúciós formulára:

\subsection{Tétel.}

$$
\sum_{k=0}^{n} B_{2 k} B_{2 n-2 k}-\sum_{k=0}^{n-1} B_{2 k+1} B_{2 n-2 k-1}=4^{n} B_{n}
$$


Bizonyítás. A közvetlen út helyett a

$$
\sum_{k=0}^{n} B_{2 k} B_{2 n-2 k}-\sum_{k=0}^{n-1} B_{2 k+1} B_{2 n-2 k-1}=\sum_{k=0}^{n} C_{2 k} B_{2 n-2 k}
$$

állítást igazoljuk, amelyból (2.8) alapján azonnal következik a bizonyítandó. A rendezéssel kapott

$$
\sum_{k=0}^{n}\left(B_{2 k}-C_{2 k}\right) B_{2 n-2 k}=\sum_{k=0}^{n-1} B_{2 k+1} B_{2 n-2 k-1}
$$

egyenlôséget látjuk be kettős leszámlálással.

Rögzítsük $n$-et. A jobb oldal azokat az $\left(O_{1}, O_{2}\right)$ rendezett párokat számolja meg, amelyekre $O_{1}$ és $O_{2}$ két olyan tetszóleges páratlan félhosszú kiegyensúlyozott út, melyek félhosszai összege $2 n$. Jelölje ezen $\left(O_{1}, O_{2}\right)$ párok halmazát $\mathcal{O}$. A 2.4. Lemma figyelembevételével a bal oldal azokat az $\left(E_{1}, E_{2}\right)$ párokat számolja meg, amelyekre $E_{1}$ és $E_{2}$ két olyan páros félhosszú kiegyensúlyozott út, melyek félhosszai összege $2 n$, továbbá $E_{1} n e m$ páros-metszô, azaz van $4 t+2$ alakú $x$-tengelymetszete. Jelölje ezen $\left(E_{1}, E_{2}\right)$ párok halmazát $\mathcal{E}$.

Megadunk egy bijekciót $\mathcal{E}$ és $\mathcal{O}$ között, ami bizonyítja az állítást. Bijekciónkat a 2.19. ábra szemlélteti. Válasszunk egy tetszóleges $\left(E_{1}, E_{2}\right)$ útpárt $\mathcal{E}$-ból. Az $E_{1}$ útnak az origótól az elsô $4 t+2$ alakú $x$-tengelymetszetig tartó részét jelölje $L$, és legyen $R$ az út többi része (tehát $E_{1}=L R$ ). Az $\left(E_{1}, E_{2}\right)$ útpár képe legyen az $\left(L E_{2}, R\right)$ útpár, mely $\mathcal{O}$-beli, mivel $L$ és $R$ páratlan félhosszú, $E_{2}$ pedig páros félhosszú kiegyensúlyozott út, és a félhosszok összege nyilván továbbra is $2 n$. Tehát egy $\mathcal{E} \rightarrow \mathcal{O}$ leképezést definiáltunk, amelyrôl könnyû meggondolni, hogy bijekció: Az inverze az a leképezés, amely az $\left(O_{1}, O_{2}\right) \in \mathcal{O}$ úthoz az $\left(L^{\prime} O_{2}, R^{\prime}\right) \in \mathcal{E}$ utat rendeli, ahol $L^{\prime}$ az $O_{1}$ út elsố $4 t+2$ alakú $x$-tengelymetszetig tartó része (ilyen alakú tengelymetszet mindig van, mert $O_{1}$ végpontja is ilyen), $R^{\prime}$ pedig az $O_{1}$ fennmaradó része.
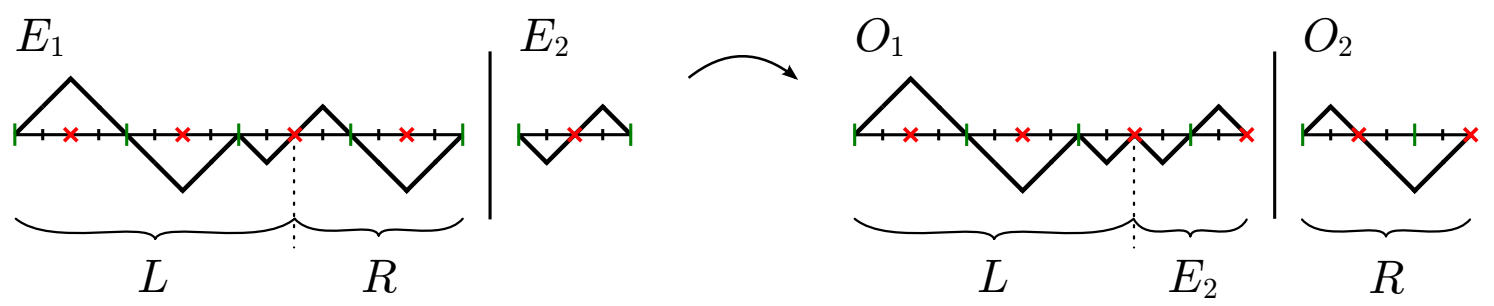

2.19. ábra: Egy bijekció az $\mathcal{E}$ és $\mathcal{O}$ halmazok között

Megjegyzés. A bijektíven bizonyított (2.11) alak a (2.8) és (2.10) formulák ekvivalenciáját mutatja, tehát (2.10) minden kombinatorikus bizonyítása egyúttal (2.8), vagyis a (2.7) Shapiro-azonosság kombinatorikus bizonyításaként is felfogható, így például Spivey eredeti bizonyítása is. $\diamond$

$$
B_{2 k}-C_{2 k}=\left(\begin{array}{c}
4 k \\
2 k-1
\end{array}\right) \text {, tehát }(2.12) \text { mindegyik tényezője binomiális együttható: }
$$




\subsection{Következmény.}

$$
\sum_{k=1}^{n}\left(\begin{array}{c}
4 k \\
2 k-1
\end{array}\right)\left(\begin{array}{c}
4 n-4 k \\
2 n-2 k
\end{array}\right)=\sum_{k=0}^{n-1}\left(\begin{array}{c}
4 k+2 \\
2 k+1
\end{array}\right)\left(\begin{array}{c}
4 n-4 k-2 \\
2 n-2 k-1
\end{array}\right)
$$

Megjegyzés. Kiemeljük, hogy a fenti bizonyításban felhasználtuk azt a tényt, hogy $B_{2 k}-C_{2 k}$ a $2 k$ félhosszú kiegyensúlyozott, nem páros-metszó utakat számolja meg. Ezt tekinthetjük a $\left(\begin{array}{c}4 k \\ 2 k-1\end{array}\right)$ binomiális együttható szokatlan kombinatorikus leírásának is. (Hozzátesszük, hogy a $B_{2 k}-C_{2 k}=\left(\begin{array}{c}4 k \\ 2 k-1\end{array}\right)$ egyenlôség könnyen igazolható kombinatorikusan; a $2 k$ félhosszú Dyck-utak számát $B_{2 k}-\left(\begin{array}{c}4 k \\ 2 k-1\end{array}\right)$ különbségként adja meg a standard tükrözéses érvelés.) $\diamond$

Végezetül a teljesség kedvéért ismertetjük Spivey (2.10)-re adott elegáns bizonyítását [28]. Ehhez szükségünk lesz a következó definíciókra. 2-(ciklus)színezett permutáció alatt a továbbiakban olyan permutációt értünk, amelynek minden ciklusához hozzárendeltünk egy színt, pirosat van kéket. (Az alaphalmaz elemei megkapják a ciklusuk színét.) A véletlen 2-színezett permutációkat uniform módon ,generáljuk": egy rögzített alaphalmaz permutációi közül véletlenül választunk egyet uniform módon, majd a kapott permutáció ciklusait pirosra vagy kékre színezzük 1/2-1/2 valószínûséggel, egymástól függetlenül. Tehát ha az alaphalmaz mérete $n$, akkor egy konkrét 2-színezett permutációt $\frac{1}{n !} \cdot \frac{1}{2^{s}}$ valószínúséggel kapunk meg, ha $s$ ciklusa van. Egy $n$ elemú halmaz $s$ ciklusból álló permutációinak számát $c(n, s)$-sel jelöljük.

A következô lemma kapcsolja össze a véletlen 2-színezett permutációkat és a középsố binomiális együtthatók konvolúcióit. A lemma Spivey eredménye előtt is ismert volt, megtalálható például [29]-ben feladatként (60. probléma).

2.18. Lemma. Legyen $0 \leq k \leq n$. Annak a valószínüsége, hogy az $\{1, \ldots, n\}$ alaphalmaz egy véletlen 2-szinezett permutációjában pontosan $k$ elem piros, $\frac{1}{4^{n}} B_{k} B_{n-k}$.

Bizonyítás. $\left(\begin{array}{l}n \\ k\end{array}\right)$-féleképpen tudjuk megválasztani a piros elemek $P$ halmazát. Minden $k$ elemú $P$ halmazra $c(k, i) c(n-k, j)$ olyan 2-színezett permutáció van, amelyben a piros elemek halmaza $P$, és a piros ciklusok száma $i$, a kék ciklusok száma $j$. Ezen 2-színezett permutációk mindegyikét $\frac{1}{n ! 2^{i+j}}$ valószínúséggel kaphatjuk meg, így az összes lehetséges $P$ halmazra és $(i, j)$ párra összegezve az adódik, hogy a lemmabeli valószínúség

$$
\left(\begin{array}{l}
n \\
k
\end{array}\right) \sum_{i=1}^{k} \sum_{j=1}^{n-k} \frac{c(k, i) c(n-k, j)}{n ! 2^{i+j}}=\frac{\left(\begin{array}{l}
n \\
k
\end{array}\right)}{n !}\left(\sum_{i=1}^{k} \frac{c(k, i)}{2^{i}}\right)\left(\sum_{j=1}^{n-k} \frac{c(n-k, j)}{2^{j}}\right)
$$

A $c(k, i)$ számok generátorfüggvénye ismert:

$$
\sum_{i=1}^{k} c(k, i) x^{i}=x(x+1) \ldots(x+k-1)
$$


melyet pozitív egész $x$ értékekre éppen színezett permutációk segítségével a legkönnyebb kombinatorikusan igazolni (mindkét oldal a ciklusszínezett permutációkat számolja meg egy $k$ elemú alaphalmazon, ha a színpaletta mérete $x$; bóvebben lásd például a [11] tankönyvben). Ennek felhasználásával, $x=\frac{1}{2}$ helyettesítéssel,

$$
\sum_{i=1}^{k} \frac{c(k, i)}{2^{i}}=\frac{1}{2} \cdot\left(\frac{1}{2}+1\right) \cdot \ldots \cdot\left(\frac{1}{2}+k-1\right)=\frac{1 \cdot 3 \cdot \ldots \cdot(2 k-1)}{2^{k}}=\frac{(2 k) !}{4^{k} k !},
$$

és ugyanígy

$$
\sum_{j=1}^{n-k} \frac{c(n-k, j)}{2^{j}}=\frac{(2 n-2 k) !}{4^{n-k}(n-k) !} .
$$

Tehát a fent kiszámolt valószínúség a következô alakba írható:

$$
\frac{\left(\begin{array}{l}
n \\
k
\end{array}\right)}{n !} \cdot \frac{(2 k) !}{4^{k} k !} \cdot \frac{(2 n-2 k) !}{4^{n-k}(n-k) !}=\frac{1}{4^{n}}\left(\begin{array}{c}
2 k \\
k
\end{array}\right)\left(\begin{array}{c}
2 n-2 k \\
n-k
\end{array}\right)
$$

amit bizonyítani kellett.

Megjegyzés. A lemmabeli valószínû́ségeket $k$ lehetséges értékeire összeadva 1-et kapunk, ami a középsố binomiális együtthatók (2.5) konvolúciós formulájának egy újabb bizonyítását adja. $\diamond$

Ezen előkészületek után ismertetjük (2.10) eredeti bizonyítását:

A 2.16. Tétel második bizonyítása. (Spivey [28]) Mindkét oldalt $4^{2 n}$-nel osztva, a bizonyítandó (2.10) azonosság a következő alakot ölti:

$$
\sum_{k=0}^{n} \frac{1}{4^{2 n}} B_{2 k} B_{2 n-2 k}-\sum_{k=0}^{n-1} \frac{1}{4^{2 n}} B_{2 k+1} B_{2 n-2 k-1}=\frac{1}{4^{n}} B_{n}
$$

A 2.18. Lemma szerint a bal oldal $p_{0}-p_{1}$, ahol $p_{0}$ (illetve $p_{1}$ ) annak a valószínûsége, hogy az $\{1, \ldots, 2 n\}$ alaphalmaz egy véletlen 2-színezett permutációjában páros (illetve páratlan) sok piros elem van. A $p_{0}-p_{1}$ különbség $\sum p_{\pi} I_{\pi}$, ahol az összegzés végigfut a $2 n$ elemú alaphalmaz összes 2-színezett $\pi$ permutációján, és $p_{\pi}$ a $\pi$,bekövetkezésének” valószínúsége; továbbá $I_{\pi}$ értéke 1 , ha $\pi$-ben páros sok piros elem van, és -1 , ha páratlan sok.

Meghatározzuk egy rögzített $\rho$ (színezetlen) permutáció 2-(ciklus)színezéseinek együttes hozzájárulását a $\sum p_{\pi} I_{\pi}$ összeghez. Ha $\rho$ mindegyik ciklusa páros hosszú, akkor nyilván minden 2-színezésében páros sok piros elem lesz, tehát ekkor az összhozzájárulás $2^{s} \frac{1}{(2 n) ! 2^{s}} \cdot 1=\frac{1}{(2 n) !}$, azaz természetesen $\rho$,kiválasztásának" valószínúsége. (Itt $s$ ismét a ciklusok számát jelölte.) Ha $\rho$-nak van páratlan hosszú ciklusa, akkor egy tetszôleges rögzített páratlan hosszú ciklus színének ,invertálásával” olyan párokba rendezhetjük $\rho$ 2-színezéseit, hogy minden párban az egyik 2-színezett ciklus páros sok piros elemet tartalmaz, a másik pedig páratlan sokat. Tehát minden 
pár 0-val járul hozzá az összeghez, vagyis a $\rho$-hoz tartozó összhozzájárulás ebben az esetben 0 .

Az eddigi meggondolások alapján (2.13) bal oldala $\left|\Pi_{2 n}\right| /(2 n)$ !, ahol $\Pi_{2 n}$ az $\{1, \ldots, 2 n\}$ alaphalmaz csak páros hosszú ciklusokat tartalmazó permutációinak halmaza. $\left|\Pi_{2 n}\right|$ meghatározásához építsük fel $\Pi_{2 n}$ permutációit ciklusonként a szokásos módon: Elôször az '1' elem képét választjuk meg, majd az '1' elem képének képét, és így tovább, záródó ciklus esetén a még nem ciklusba rendezett elemek közül a legkisebb elem képének (és egész ciklusának) meghatározásával folytatjuk az eljárást mindaddig, amíg a permutációt teljesen nem definiáljuk. Ebból

$$
\left|\Pi_{2 n}\right|=(2 n-1) \cdot(2 n-1) \cdot(2 n-3) \cdot(2 n-3) \cdot \ldots \cdot 1 \cdot 1,
$$

mert az $i$-edik lépésben az aktuális elem képe vagy a még „érintetlen" $2 n-i$ elem közül kerülhet ki, vagy az épp felépítés alatt lévő ciklust zárhatjuk be, de utóbbi csak akkor engedélyezett, ha $i$ páros (az elsố ciklust csak valamelyik párosadik lépésben zárhatjuk be, majd ismét páros sok lépésnek kell eltelnie a következő ciklus bezárásáig stb.). Itt hallgatólagosan felhasználtuk azt a könnyen ellenőrizhetô tényt, hogy a leírt felépítési eljárások halmaza és a $\Pi_{2 n}$ halmaz között bijektív kapcsolat van.

Összegezve tehát (2.13) bal oldala

$$
\frac{\left|\Pi_{2 n}\right|}{(2 n) !}=\frac{(2 n-1) \cdot(2 n-1) \cdot(2 n-3) \cdot(2 n-3) \cdot \ldots \cdot 1 \cdot 1}{(2 n) !}=\frac{(2 n) !(2 n) !}{(2 n) ! 2^{n} n ! 2^{n} n !}=\frac{B_{n}}{4^{n}}
$$

amit bizonyítani kellett.

\subsection{További problémák}

Ebben az alfejezetben sejtésként fogalmazzuk meg a 2.7. Lemma egy általánosítását. A páros-metszố utak definiálásakor az $x$-tengelyen a lehetséges tengelymetszetek közül minden másodikat megtiltottunk, a többit pedig engedélyeztük. Most más „tiltásmintákat” is megvizsgálunk.

A különbözố tiltásminták megadhatók egy-egy sorozattal, amelyek a szóba jöhető tengelymetszetekre balról jobbra haladva felsorolják, hogy a metszéspont tiltott vagy engedélyezett-e. Kiderül, hogy akkor jutunk érdekes sejtésekhez, ha bevezetünk egy harmadik fajta eloóírást is.

Definíció. Egy $b_{0}, b_{1}, \ldots, b_{n}$ 0-1-2 sorozatra jelölje $\mathcal{P}\left[b_{0} b_{1} \ldots b_{n}\right]$ azon $2 n$ hosszú, origóból induló (hagyományos) utak halmazát, amelyek elkerülik a $\left\{(2 i, 0): b_{i}=0\right\}$ halmaz összes pontját, ugyanakkor a $\left\{(2 i, 0): b_{i}=2\right\}$ halmaz legalább egy pontjára rálépnek. (Figyeljük meg, hogy a sorozat (hossza) kijelöli az utak hosszát is.) $\diamond$

A tömörebb írásmód kedvéért egy 0-1-2 sorozat megadásakor az ismétlődő részeket hatványozásszerúen jelöljük, például az 110110110 bitsorozatot írhatjunk $\left(1^{2} 0\right)^{3}$-ként is. 


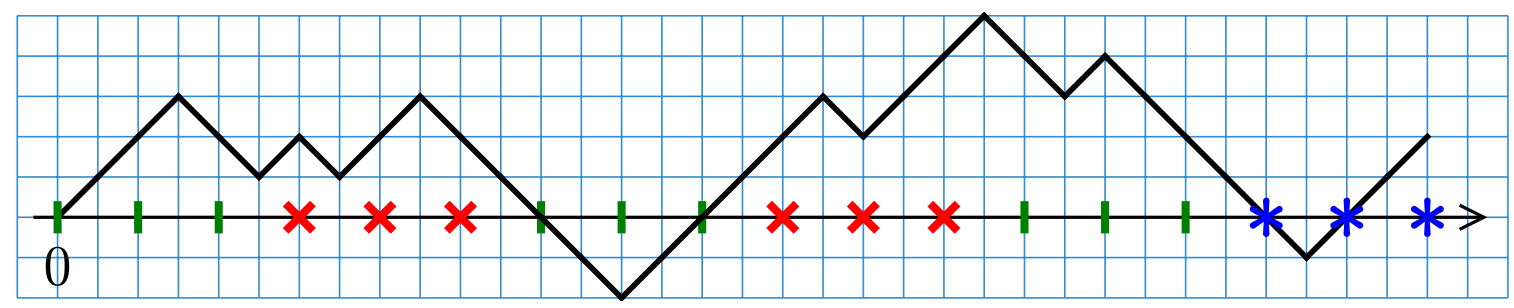

2.20. ábra: A $\mathcal{P}\left[\left(1^{3} 0^{3}\right)^{2} 1^{3} 2^{3}\right]$ halmaz egy útja $(0=\times, 1=\mid, 2=*)$

Minden ilyen elő́rás-sorozathoz tartozik egy összeszámlálási probléma, a kijelölt utak számának meghatározása. Ez a feladat a 14. oldalon ismertetett egyszerú algoritmus analógiájára hatékonyan megoldható számítógép segítségével. A késóbb megfogalmazott sejtéseket leellenőriztük ezzel a módszerrel „kezelhetô” úthosszok (definiáló sorozathosszok) esetén, ám teljes bizonyításuk még várat magára. (A kombinatorikus bizonyítás a cél, de egyéb bizonyítást sem ismerünk.)

A következô sejtés a 2.7. Lemma általánosítása. Ez az általános sejtés azt sugallja, hogy a lemmára adott, 2.3. alfejezetben bemutatott bizonyításunk talán egyszerûsíthetô. (Mivel a konstrukció nem vihetô át az általános esetre, vagy legalábbis nem nyilvánvaló módon.)

\subsection{Sejtés.}

a) $\left|\mathcal{P}\left[\left(1^{k} 0^{k}\right)^{n-1} 1^{k} 2^{k}\right]\right|=\left|\mathcal{P}\left[10^{n-1} 21^{2 k n-n-1}\right]\right|=4^{2 k n-n-1} 2 C_{n-1}$,

b) $\left|\mathcal{P}\left[\left(1^{k} 0^{k}\right)^{n}\right]\right|=\left|\mathcal{P}\left[10^{n} 1^{2 k n-n-1}\right]\right|=4^{2 k n-n-1} B_{n}$.

Megjegyzés. Az állításokban szereplő halmazok mindegyike $4 k n-2$ hosszú utakat tartalmaz. A második egyenlôség mindkét esetben nyilvánvaló: A b) pontban $\mathcal{P}\left[10^{n}\right]$ a $2 n$ hosszú seholsem-zéró utak halmaza (ld. 8. oldal); így a 2.2. Állítás szerint $\left|\mathcal{P}\left[10^{n}\right]\right|=B_{n}$, és egy utolsó 1 -es hozzáadása egy $\boldsymbol{b}$ 0-1-2 sorozathoz két tetszóleges befejezô lépés hozzávételét jelenti a $\mathcal{P}[\boldsymbol{b}]$-beli utak halmazához, ami a számosságokat tekintve egy 4-szeres szorzónak felel meg; tehát valóban adódik b) utolsó egyenlősége. Az a) pontban pedig a $\mathcal{P}\left[10^{n-1} 2\right]$-beli utak éppen a $2 n-2$ hosszú Dyck-utak, egy kezdô felfelé és záró lefelé lépéssel ellátva, valamint ezek $x$-tengelyre vonatkozó tükörképei; tehát $\left|\mathcal{P}\left[10^{n-1} 2\right]\right|=2 C_{n-1}$, vagyis a második egyenlôség ismét egyszerúen következik. Az igazi feladat tehát a $\mathcal{P}\left[\left(1^{k} 0^{k}\right)^{n-1} 1^{k} 2^{k}\right]$ és $\mathcal{P}\left[\left(1^{k} 0^{k}\right)^{n}\right]$ halmazok elemszámának meghatározása; a $\mathcal{P}\left[10^{n-1} 21^{2 k n-n-1}\right]$ és $\mathcal{P}\left[10^{n} 1^{2 k n-n-1}\right]$ halmazok szerepeltetésével csupán egy-egy lehetséges „,élhalmazt” adtunk egy bijektív bizonyításhoz, illetve kiemeltük vele, hogy a tiltásmintában a blokkok száma „lényegesebbnek tünik", mint a blokkok mérete. $\diamond$

Vegyük észre, hogy $k=1$ választással valóban visszakapjuk a 2.7. Lemmát. A sejtés b) pontja szerint $\left|\mathcal{P}\left[(10)^{n}\right]\right|=4^{n-1} B_{n}$, és tekintve, hogy a $4 n$ hosszú páros-metszố utak éppen $\mathcal{P}\left[(10)^{n}\right]$ útjaiból nyerhetook 2 tetszóleges befejezô lépés hozzáfúzésével, az állítás valóban a lemma b) pontjának felel meg. Az a) pontok ekvivalenciája pedig abból következik, hogy a $\mathcal{P}\left[(10)^{n} 12\right]$ útjai éppen az origóból a $(4 n+1,1)$ pontba menô páros-metsző utak és tükörképeik (egy $x$-tengelyre vivő lépés hozzávételével). 
Valójában a sejtés két pontja is ekvivalens, bár ezt nem teljesen kombinatorikus úton látjuk be. Ha $\mathcal{P}\left[\left(1^{k} 0^{k}\right)^{n}\right]$ útjait úgy számoljuk meg, hogy az összes $4 k n-2$ hosszú utak számából kivonjuk az $x$-tengelyt tiltott pontban metszô utak számát (a „rossz" utakat aszerint csoportosítva, hogy melyik tiltott blokkra léptek rá elôször), akkor a

$$
\begin{aligned}
\left|\mathcal{P}\left[\left(1^{k} 0^{k}\right)^{n}\right]\right| & =2^{4 k n-2}-\sum_{i=1}^{n}\left|\mathcal{P}\left[\left(1^{k} 0^{k}\right)^{i-1} 1^{k} 2^{k} 1^{2 k(n-i)}\right]\right| \\
& =2^{4 k n-2}-\sum_{i=1}^{n}\left|\mathcal{P}\left[\left(1^{k} 0^{k}\right)^{i-1} 1^{k} 2^{k}\right]\right| 4^{2 k(n-i)}
\end{aligned}
$$

összefüggéshez jutunk. Feltéve, hogy a sejtés a) állításának elsô egyenlősége igaz, és felhasználva, hogy ekkor nyilvánvalóan úgy is igaz, ha a két úthalmazt definiáló sorozathoz ugyanannyi záró 1-es bitet hozzáveszünk, (2.14) elsố egyenlôségéból a

$$
\begin{aligned}
\left|\mathcal{P}\left[\left(1^{k} 0^{k}\right)^{n}\right]\right| & =2^{4 k n-2}-\sum_{i=1}^{n}\left|\mathcal{P}\left[10^{i-1} 21^{2 k i-i-1} 1^{2 k(n-i)}\right]\right| \\
& =2^{4 k n-2}-\sum_{i=1}^{n}\left|\mathcal{P}\left[10^{i-1} 21^{2 k n-i-1}\right]\right|=\left|\mathcal{P}\left[10^{n} 1^{2 k n-n-1}\right]\right|
\end{aligned}
$$

alakot kapjuk, ahogy a b) pont állítja. Az utolsó egyenlôség azért teljesül, mert az egyenlőség jobb oldalán álló mennyiséget ismét úgy számoljuk meg, hogy az összes szóba jöhetô utak számából kivonjuk a „rossz” utak számát. Megfordítva, a b) állításból rekurzívan következik a), mert $k$-t rögzítve, (2.14) rendezés után egy rekurzív kiszámítási módot ad az $a_{n}:=\left|\mathcal{P}\left[\left(1^{k} 0^{k}\right)^{n-1} 1^{k} 2^{k}\right]\right|$ sorozat elemeire a kisebb indexú $a_{i}$ értékekból és a $\left|\mathcal{P}\left[\left(1^{k} 0^{k}\right)^{n}\right]\right|$ értékéból, amely rekurziót egyetlen $\left\{a_{n}\right\}_{n=1}^{\infty}$ sorozat elégít ki; és a $\left|\mathcal{P}\left[\left(1^{k} 0^{k}\right)^{n}\right]\right|=\left|\mathcal{P}\left[10^{n} 1^{2 k n-n-1}\right]\right|$ feltételezéssel élve a $\left\{\left|\mathcal{P}\left[10^{n-1} 21^{2 k n-n-1}\right]\right|\right\}_{n=1}^{\infty}$ sorozat ilyen, ezt láttuk be az elóbb.

Befejezésként ismertetünk egy hasonló sejtést, amelyet számítógépes vizsgálataink során fogalmaztunk meg. (A két alpont ekvivalenciája a fentiekhez hasonlóan igazolható.) A második úthalmazt definiáló tiltássorozatban az '1' kitevôje mindkét állításban az az érték, amellyel a sorozat ugyanolyan hosszú lesz, mint az elsó tiltássorozat.

\subsection{Sejtés.}

a) $\left|\mathcal{P}\left[1\left(1^{k} 0^{k+1}\right)^{n-1} 1^{k} 2^{k+1}\right]\right|=\left|\mathcal{P}\left[10^{n-1} 21^{2 k n}\right]\right|=4^{2 k n} 2 C_{n-1}$,

b) $\left|\mathcal{P}\left[1\left(1^{k} 0^{k+1}\right)^{n}\right]\right|=\left|\mathcal{P}\left[10^{n} 1^{2 k n}\right]\right|=4^{2 k n} B_{n}$. 


\section{Diszkrét véletlen séták egy konvexitási tulajdonsága}

\subsection{Bevezetés}

Ebben a fejezetben diszkrét véletlen sétákkal foglalkozunk a síkon, illetve magasabb dimenziókban. Megvizsgáljuk a $\mathbb{Z}^{2}$ négyzetrács egy rögzített pontjából indított véletlen séta $x$-tengellyel vett elsố metszéspontjának eloszlását konvexitás szempontjából, majd tekintjük a probléma $\mathbb{Z}^{d}$-beli megfelelőjét.

A bemutatásra kerülő eredmények elốzménye Benkô Dávid, Peter D. Dragnev és Totik Vilmos 2012-ben megjelent [2] cikke, melyben a szerzők egyebek mellett iterált kisöprés („balayage”) alkalmazásával bizonyítják, hogy a komplex sík valós egyenesének tetszóleges kompakt halmazához társított harmonikus mérték sûrúségfüggvénye konvex (a halmaz részintervallumain). A harmonikus mértékek alapvető szerepet töltenek be a harmonikus analízisben (a témakört részletesen tárgyalja például a [7] monográfia); mi a standard definíció helyett az értekezés témájához kapcsolódó ekvivalens módon vezetjük be az idézett tételben szereplő harmonikus mértéket: Adott egy, az origót nem tartalmazó $K \subset \mathbb{R}$ kompakt halmaz a komplex sík valós egyenesén, és legyen $\omega_{K}$ az a mérték, amely minden $H \subseteq K$ mérhetô részhalmazhoz annak az eseménynek a valószínúséget rendeli, hogy az origóból induló 2-dimenziós Brown-mozgás meglátogatja $K$-t, és az elsô meglátogatott pont $H$-beli. (A valószínúségelmélet és a harmonikus analízis kapcsolatáról bővebben olvashatunk például az [5] könyvben.) A fenti eredmény állítása szerint ez az $\omega_{K}$ mérték abszolút folytonos, és (alkalmas) súrûségfüggvénye konvex minden $I \subseteq K$ intervallumon. Totik professzorral közös [18] cikkünkben erre a tételre egy új bizonyítást adunk, amely azon a jól ismert tényen alapul, hogy a 2-dimenziós Brown-mozgás közelíthetô (egyre finomodó négyzetrácson tekintett) diszkrét véletlen sétákkal. Az én hozzájárulásom ehhez a bizonyításhoz a diszkretizált változatban felmerülő kombinatorikus probléma, a 3.1. Tétel elemi megoldása volt, ezért ezzel foglalkozunk majd részletesebben. (Ezt a tételt Totik Vilmos igazolta először, más eszközökkel.) A következőkben a szükséges fogalmak bevezetése után ismertetjük a tételt, melyet a 3.2. alfejezetben bizonyítunk majd. A 3.3. alfejezet Szalai Attilával közös eredményeket tartalmaz [17]: Egy általánosítással foglalkozunk, melyet Totik Vilmos ajánlott figyelmünkbe, a folytonos analógia által sugallt iránymutatásokkal együtt. Itt megvizsgáljuk módszerünk korlátait is. Végül a 3.4. alfejezetben eredményeink magasabb dimenziós megfelelőit tárgyaljuk.

Most bevezetjük a fejezetben használt fogalmakat. Egy $(m, n) \in \mathbb{Z}^{2}$ rácspont $\left(\mathbb{Z}^{2}\right.$-beli) szomszédain az $(m+1, n),(m-1, n),(m, n+1)$ és $(m, n-1)$ pontokat értjük.

Definíció. Egy $\mathbb{Z}^{2}$-beli (rács)pontokból álló $Q_{0}, Q_{1}, Q_{2}, \ldots$ (véges vagy végtelen) 
sorozat 2-dimenziós diszkrét séta (röviden: $\mathbb{Z}^{2}$-beli séta), ha mindegyik (nem utolsó) $Q_{i}$ pontot valamely $\mathbb{Z}^{2}$-beli szomszédja követi a sorozatban (vagyis $Q_{i}$ és $Q_{i+1}$ szomszédosak).

A $Q_{0}, Q_{1}, Q_{2} \ldots$ séta egyértelmúen leírható a $Q_{0}$ kezdôpont és a $Q_{1}-Q_{0}$, $Q_{2}-Q_{1}, Q_{3}-Q_{2}, \ldots$ (vektor)sorozat megadásával is. A $Q_{i}-Q_{i-1}$ vektort a séta $i$-edik lépésének nevezzük. Mivel egy pontból mindig szomszédos rácspontra lépünk, egy $\mathbb{Z}^{2}$-beli séta lépései a $(0,1),(0,-1),(-1,0)$ és $(1,0)$ vektorok közül kerülhetnek ki, melyekre rendre felfelé $(\uparrow)$, lefelé $(\downarrow)$, balra $(\leftarrow)$ és jobbra $(\rightarrow)$ lépésként hivatkozunk. Egy (véges) $W$ séta hosszán a lépései számát értjük (azaz a $Q_{0}, Q_{1}, Q_{2}, \ldots$ sorozat hosszánál eggyel kisebb értéket), melyet $|W|$-vel jelölünk. $\diamond$

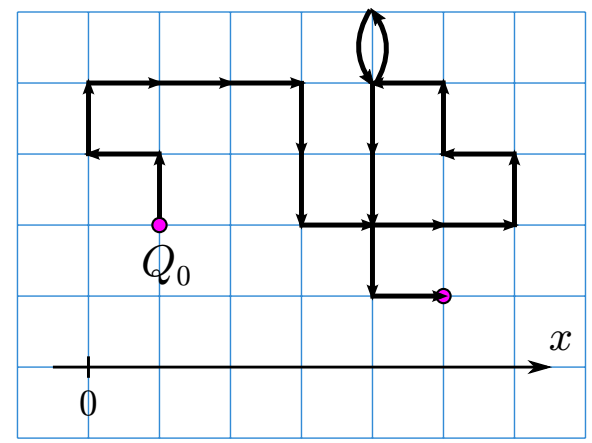

3.1. ábra: Egy 21 hosszú séta

Természetesen a $\mathbb{Z}^{2}$-beli sétákra a 3.1. ábrán látható módon gondolunk, illetve használjuk a szemléletból eredő fogalmakat (pl. $x$-tengelymetszet, tükrözés stb.).

Definíció. Egy adott $Q_{0}$ pontból induló $\mathbb{Z}^{2}$-beli (szimmetrikus) véletlen séta alatt egy, a következô véletlen eljárással generált $\mathbb{Z}^{2}$-beli $Q_{0}, Q_{1}, Q_{2}, \ldots$ végtelen sétát értünk: A $Q_{0}$ pontból indulva mindig véletlenszerúen - uniform módon és a korábbi döntéseinktól függetlenül - választjuk ki, hogy az aktuális $Q_{i}$ pont 4 szomszédja közül melyikre lépünk (melyikük lesz $Q_{i+1}$ ). Tehát, formálisan, legyenek $\xi_{1}, \xi_{2}, \ldots$ független véletlen változók, melyek értékei a $\{\uparrow, \downarrow, \leftarrow, \rightarrow\}$ vektorhalmazból kerülnek ki uniform módon (1/4-1/4 valószínüséggel); ekkor a $\left(Q_{0}+\sum_{i=1}^{n} \xi_{i}\right)_{n=0}^{\infty}$ véletlen sorozatot $Q_{0}$-ból induló ( $\mathbb{Z}^{2}$-beli) véletlen sétának nevezzük. $\diamond$

Most ismertetjük az ígért diszkrét eredményt, Totik Vilmossal közös [18] cikkünk lemmáját, amelyre visszavezethetô a [2] cikk harmonikus mértékekre vonatkozó folytonos eredménye.

3.1. Tétel. Legyen $p_{k}$ annak a valószinúsége, hogy a $(0,1)$ pontból induló $\mathbb{Z}^{2}$-beli véletlen séta a $(k, 0)$ pontban lép elôször az $x$-tengelyre $(k \in \mathbb{Z})$. Ekkor a $\left(p_{k}\right)_{k=0}^{\infty}$ sorozat konvex, vagyis $p_{k} \leq \frac{1}{2}\left(p_{k-1}+p_{k+1}\right)$ teljesül $k \geq 1$ esetén.

Megjegyzés. A „, $(k, 0)$ pontban lép először az $x$-tengelyre” esemény definíció szerint nem következik be, ha a séta soha nem lép az $x$-tengelyre. (A hasonló módon megfogalmazott eseményeket így értjük a késóbbiekben is.) De valójában ezzel az esettel nem kell foglalkozni, ugyanis meggondolható, hogy a $(0,1)$ pontból induló 
véletlen séta 1 valószínúséggel rálép az $x$-tengelyre, és így a tételbeli $p_{k}$ valószínúségek összege 1. (Bár ezt a tényt nem fogjuk használni.) $\diamond$

A 3.1. Tételt a következő alfejezetben bizonyítjuk. Most két másik lehetséges bizonyítási módot vázolunk.

Először Totik Vilmos gondolatmenetét mutatjuk be. A $\left(p_{k}\right)_{k \in \mathbb{Z}}$ sorozathoz mint együttható-sorozathoz tartozó (komplex) Fourier-sor összege könnyen meghatározható (lásd pl. [18]-ban, vagy a [27] monográfia 156. oldalán, illetve vázlatosan a következô alfejezetben):

$$
g(x)=\sum_{k=-\infty}^{\infty} p_{k} e^{i k x}=2-\cos x-\sqrt{(1-\cos x)(3-\cos x)} .
$$

A 3.1. Tétel bizonyításához a $g(x)$ elemi függvény nemnegatív indexú Fourieregyütthatóira kell igazolni a konvexitáshoz szükséges egyenlőtlenségeket. Ez a megközelítés a Fourier-együtthatók kiszámítási módja alapján elemi függvények határozott integráljai között fennálló egyenlőtlenségekhez vezet. Amely egyenlótlenségek bizonyítása elvégezhető, de nem egyszerú feladat. (Ez a nehezebb technikai rész végül nem került publikálásra.)

A 3.3. alfejezetben látni fogjuk, hogy a 3.1. Tétel igazolható a szép kombinatorikus ötlettel nyerhetô (korábban is ismert) 3.8. Következményból kiindulva egy kevésbé szép, de elemi számolással. Ez tételünk egy újabb bizonyítását adja.

A következô alfejezetben egy számolásmentes módszert ismertetünk, melyben a bizonyítandó egyenlőtlenséget injektív függvény megadásával igazoljuk.

\subsection{A diszkrét konvexitási lemma elemi bizonyítása}

Ebben az alfejezetben a [18] cikkben publikált módon igazoljuk a 3.1. Tételt. Elôször bevezetünk néhány elnevezést és jelölést. Legyen $p_{k_{2}}^{\left(k_{1}, h\right)}$ annak az eseménynek a valószínúsége, hogy a $\left(k_{1}, h\right)$ pontból indított $\mathbb{Z}^{2}$-beli véletlen séta a $\left(k_{2}, 0\right)$ pontban lép elôször az $x$-tengelyre. Ezzel a jelöléssel feladatunk a $\left(p_{k}^{(0,1)}\right)_{k=0}^{\infty}$ sorozat konvexségének igazolása. Megjegyezzük, hogy szimmetriai okokból nyilván fennáll, hogy $p_{k_{2}}^{\left(k_{1}, h\right)}=p_{k_{2}-k_{1}}^{(0, h)}$ és $p_{k}^{(0, h)}=p_{-k}^{(0, h)}$. Megmutatható, hogy intuíciónkkal összhangban a $\left(p_{k}^{(0, h)}\right)_{k=0}^{\infty}$ sorozat szigorúan monoton csökken tetszóleges pozitív $h$-ra. (Ez utóbbi tényt nem fogjuk használni.)

A $p_{k_{2}}^{\left(k_{1}, h\right)}$ valószínúségek becsléséhez az alábbi sétákra lesz szükségünk:

Definíció. Legyen $h>0$. Azt mondjuk, hogy egy $\mathbb{Z}^{2}$-beli (véges, nem véletlen) $\left(k_{1}, h\right) \rightsquigarrow\left(k_{2}, 0\right)$ séta pozitiv, ha az utolsó lépését megelőzően mindig szigorúan az $x$-tengely fölött tartózkodik. A továbbiakban $\mathcal{W}_{k_{2}}^{\left(k_{1}, h\right)}$ jelöli a $\mathbb{Z}^{2}$-beli pozitív $\left(k_{1}, h\right) \rightsquigarrow\left(k_{2}, 0\right)$ séták (végtelen) halmazát, továbbá $\mathcal{W}_{k_{2}}^{\left(k_{1}, h\right)}[l]$ jelöli az $l$ hosszú $\mathcal{W}_{k_{2}}^{\left(k_{1}, h\right)}$-beli séták (véges) halmazát. $\diamond$ 
Visszatérve a 3.1. Tétel $p_{k}:=p_{k}^{(0,1)}$ jelöléséhez, $k \geq 1$ esetén

$$
p_{k}=\frac{1}{4} p_{k}^{(1,1)}+\frac{1}{4} p_{k}^{(-1,1)}+\frac{1}{4} p_{k}^{(0,2)}=\frac{1}{4} p_{k-1}+\frac{1}{4} p_{k+1}+\frac{1}{4} p_{k}^{(0,2)},
$$

hiszen $\frac{1}{4} p_{k}^{(1,1)}$ (illetve $\frac{1}{4} p_{k}^{(-1,1)}$ és $\frac{1}{4} p_{k}^{(0,2)}$ ) annak a valószínúsége, hogy a $(0,1)$ pontból induló véletlen séta elsố lépése $\rightarrow$ (illetve $\leftarrow, \uparrow$ ), és a séta a $(k, 0)$ pontban lép elôször az $x$-tengelyre. (Ha az elsô lépés lefelé lépés, akkor nem következik be a vizsgált esemény $k \geq 1$ esetén.) Ugyanis $1 / 4$ valószínúséggel lesz az elsô lépés jobbra lépés, illetve $p_{k}^{(1,1)}$ a valószínúsége annak, hogy a séta többi lépése, az $(1,1)$ pontból indított véletlen séta olyan, hogy az első $x$-tengelymetszet a $(k, 0)$ pontban történik meg. (A $\frac{1}{4} p_{k}^{(-1,1)}$ és $\frac{1}{4} p_{k}^{(0,2)}$ tagokat hasonlóan kapjuk.) A második egyenlôség a $p_{k}^{(1,1)}=p_{k-1}$ és $p_{k}^{(-1,1)}=p_{k+1}$ összefüggésekból következik.

Megjegyzés. A $(0,2)$ pontból induló véletlen séta $y=1$ egyenessel vett elsố metszéspontját vizsgálva kapjuk, hogy

$$
p_{k}^{(0,2)}=\sum_{j=-\infty}^{\infty} p_{j} p_{k-j} .
$$

Nem nehéz meggondolni, hogy ebból és (3.2)-ból következik (3.1), összefüggéseink ugyanis megfogalmazhatók a $g(x)$ Fourier-sor segítségével:

$$
g(x)=\frac{1}{4}+\frac{1}{4}\left(e^{i x}+e^{-i x}\right) g(x)+\frac{1}{4} g^{2}(x) .
$$

Itt felhasználtuk, hogy (3.2) valójában minden $k \neq 0$-ra igaz, $k=0$ esetén pedig minden lefelé lépéssel kezdődő véletlen séta is hozzájárul a $p_{k}$ valószínúséghez, így (3.2) ebben az esetben a $p_{0}=\frac{1}{4}+\frac{1}{4} p_{-1}+\frac{1}{4} p_{1}+\frac{1}{4} p_{0}^{(0,2)}$ összefüggésre módosul. A kapott függvényegyenlet $(|g(x)| \leq 1$ figyelembevételével) egyértelmú megoldása adja a (3.1)-beli zárt alakot. Megjegyezzük, hogy elemi bizonyításunk nem támaszkodik a (3.3) konvolúciós formulára, csupán közbevetésként vázoltuk az analitikus megközelítések kiindulópontjául szolgáló (3.1) sorösszeg levezetését. $\diamond$

Ha $k \geq 1$, akkor a bizonyítandó

$$
p_{k} \leq \frac{1}{2}\left(p_{k-1}+p_{k+1}\right)
$$

egyenlőtlenség (3.2) szerint ekvivalens a következôvel (amely, mint látni fogjuk, $k=0$ esetén is teljesül):

$$
p_{k}^{(0,2)} \leq p_{k-1}+p_{k+1}
$$

Ismét használva, hogy $p_{k-1}=p_{k}^{(1,1)}$ és $p_{k+1}=p_{k}^{(-1,1)}$, ezen egyenlőtlenséget a

$$
p_{k}^{(0,2)} \leq p_{k}^{(1,1)}+p_{k}^{(-1,1)}
$$


alakban látjuk be (tetszóleges $k$-ra). A vizsgált eseményt realizáló sétákat az elsố $x$-tengelymetszetig tartó szakaszuk szerint osztályozva kapjuk, hogy

$$
p_{k_{2}}^{\left(k_{1}, h\right)}=\sum_{W \in \mathcal{W}_{k_{2}}^{\left(k_{1}, h\right)}}\left(\frac{1}{4}\right)^{|W|}=\sum_{l=1}^{\infty}\left|\mathcal{W}_{k_{2}}^{\left(k_{1}, h\right)}[l]\right|\left(\frac{1}{4}\right)^{l},
$$

így a bizonyítandó (3.5) egyenlótlenség adódik a következô lemmából (a (3.5)-beli valószínúségeket (3.6) szerint végtelen sorként felírva, tagonként becsülhetünk):

3.2. Lemma. Bármely $k$ egész számra létezik hossztartó $\mathcal{W}_{k}^{(0,2)} \rightarrow \mathcal{W}_{k}^{(1,1)} \cup \mathcal{W}_{k}^{(-1,1)}$ injektiv leképezés. Vagyis tetszóleges $k \in \mathbb{Z}$ és $l \in \mathbb{N}$ esetén

$$
\left|\mathcal{W}_{k}^{(0,2)}[l]\right| \leq\left|\mathcal{W}_{k}^{(1,1)}[l]\right|+\left|\mathcal{W}_{k}^{(-1,1)}[l]\right|
$$

Bizonyítás. Megadunk egy alkalmas $\phi$ leképezést. Legyen $W \in \mathcal{W}_{k}^{(0,2)}$ egy tetszôleges $(0,2) \rightsquigarrow(k, 0)$ pozitív séta.

Először egy természetes „első próbálkozást” mutatunk be. Ha $W$ jobbra lépéssel kezdődik, akkor ezt a lépést felfelé lépésre cserélve egy $\mathcal{W}_{k}^{(1,1)}$-beli sétához jutunk; ha $W$ lefelé lépéssel kezdődik, akkor ezt a lépést jobbra lépésre cserélve egy $\mathcal{W}_{k}^{(-1,1)}$ beli sétához jutunk. Ezek az átalakítások nyilván hossztartók és injektívek. Ezt a naiv elindulást fogjuk kiterjeszteni (általánosítani) az összes $\mathcal{W}_{k}^{(0,2)}$-beli sétára.

Eljárásunk a következô. Jelölje rendre $\uparrow_{t}, \downarrow_{t}$, illetve $\rightarrow_{t}$ a $W$ séta elsó $t$ lépése között előforduló felfelé, lefelé, illetve jobbra lépések számát. Legyen $t_{0}$ a legkisebb olyan $t$ természetes szám (,időpont”), amelyre a következók valamelyike teljesül:

$$
\begin{aligned}
\rightarrow_{t} & =\uparrow_{t}+1, \\
\downarrow_{t} & =\rightarrow_{t}+1 .
\end{aligned}
$$

Ilyen $t_{0}$ létezik: Kezdetben, $t=0$-ra, $\rightarrow_{t} \leq \uparrow_{t}$ és $\downarrow_{t} \leq \rightarrow_{t}$ áll fenn (mindegyik érték 0). Egy lépés megtételével ( $t$ értékének 1-gyel való növelésével) a három megfigyelt lépésszám közül legfeljebb az egyik 1-gyel nô, a többi nem változik. Tehát $t_{0}$ az elsố olyan idôpont, amikor a jobbra lépések száma meghaladja (1-gyel) a felfelé lépések számát, vagy a lefelé lépések száma meghaladja (1-gyel) a jobbra lépések számát. Ilyen időpont létezik, mert $\uparrow_{|W|-1}<\downarrow_{|W|-1}$, hiszen közvetlenül az utolsó (lefelé) lépés elôtt a $(k, 1)$ pontban tartózkodik $W$, a kiinduló magasságánál 1 egységgel alacsonyabban, emiatt $t=|W|-1$-re nem állhat fenn $\uparrow_{t} \geq \rightarrow_{t}$ és $\rightarrow_{t} \geq \downarrow_{t}$ mindegyike, mert abból $\uparrow_{t} \geq \downarrow_{t}$ következne. Egyúttal azt is megkaptuk, hogy $t_{0} \leq|W|-1$. (A lemmabeli $\mathcal{W}$ halmazok sétáinak utolsó lépése mindig lefelé lépés, ezeket természetesen változatlanul hagyjuk majd.) A (3.9) és (3.10) feltételek közül nyilván csak az egyiket elégíti ki $t_{0}$; az elsố esetben a $t_{0}$-adik lépés jobbra lépés, a második esetben lefelé lépés.

1. eset: Ha $t_{0}$ a (3.9) feltételt teljesíti, akkor a $\phi(W)$ képet úgy definiáljuk, hogy $W$ első $t_{0}$ lépése között a jobbra lépéseket felfelé lépésekre, a felfelé lépéseket pedig jobbra lépésekre cseréljük, a többi lépést változatlanul hagyjuk, és a kapott sétát az $(1,1)$ pontból indítjuk (ld. 3.2. ábra). 

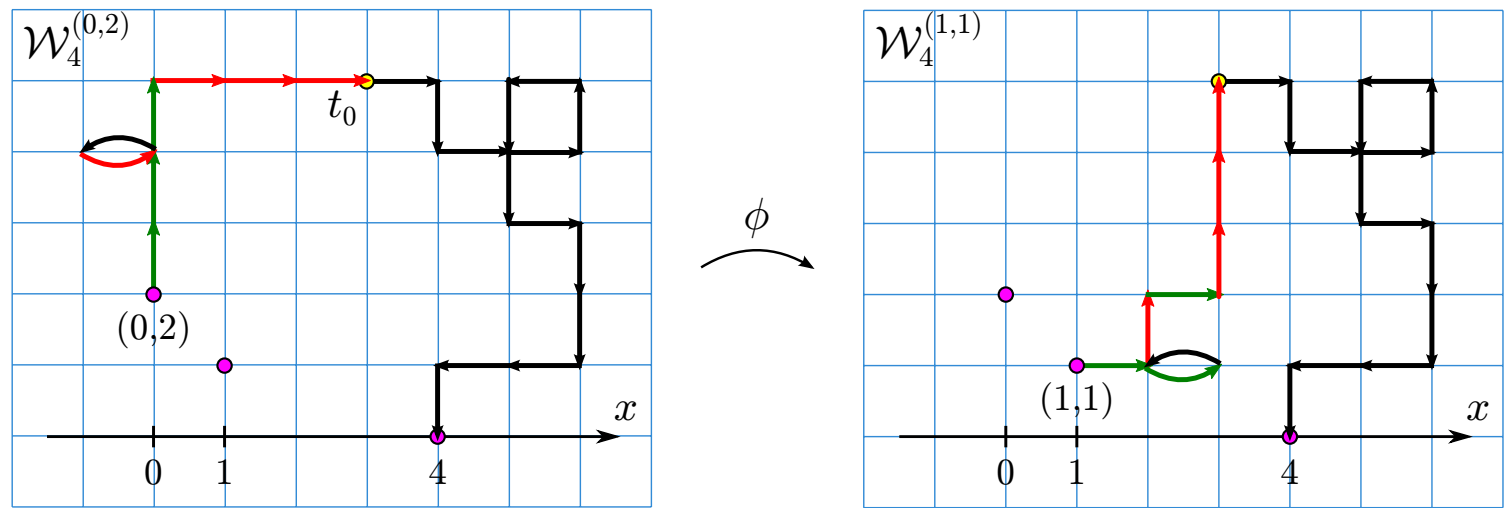

3.2. ábra: Kódolás az 1. esetben

Világos, hogy $|\phi(W)|=|W|$. Belátjuk, hogy $\phi(W) \in \mathcal{W}_{k}^{(1,1)}$ is teljesül. Mivel a cserékkel az első $t_{0}$ lépés között a jobbra lépések száma 1-gyel csökkent, a felfelé lépések száma 1-gyel nôtt (és a többi lépésszám nem változott), ezért a $\phi(W)$ séta elsố $t_{0}$ lépése által alkotott $\phi(W)_{\leq t_{0}}$ részséta végpontja megegyezik a $W$ séta elsô $t_{0}$ lépése által alkotott $W_{\leq t_{0}}$ részséta végpontjával. (Amely végpont $t_{0} \leq|W|-1$ miatt az $x$-tengely felett helyezkedik el.) Tehát a $t_{0}$-adik lépés után $\phi(W)$ egybeesik $W$ vel, mivel ezen a szakaszon $\phi(W)$-ben megtartottuk $W$ lépéseit. Speciálisan, $\phi(W)$ végpontja $(k, 0)$, és a $t_{0}$-adik lépés után végig az $x$-tengely fölött halad (a végpontot leszámítva). Annak igazolásához, hogy a $\phi(W)_{\leq t_{0}}$ szakasz is végig az $x$-tengely fölött halad, azt kell megmutatni, hogy $\downarrow_{t}^{\phi} \leq \uparrow_{t}^{\phi}$ fennáll, ha $t \leq t_{0}$. (A $\phi(W)$ beli lépésszámokat a $W$ sétánál bevezetett módon jelöljük, csak $\phi$ felsố indexszel ellátva.) Ez pedig $t_{0}$ definíciójából következik: $W$-ben $\downarrow_{t} \leq \rightarrow_{t}$ teljesül minden $t \leq t_{0}$-ra (emlékeztetünk, hogy $t_{0}$ az elsó olyan időpont, amelyre a fenti két feltétel valamelyike - esetünkben (3.9) - teljesül), ami az első $t_{0}$ lépés között végrehajtott $\rightarrow / \uparrow$ lépéscserék következtében éppen a kívánt $\downarrow_{t}^{\phi} \leq \uparrow_{t}^{\phi}$ egyenlőtlenséghez vezet $t \leq t_{0}$ esetén. Ezzel beláttuk, hogy $\phi(W) \in \mathcal{W}_{k}^{(1,1)}$, vagyis ebben az esetben $\phi$ jóldefiniált.
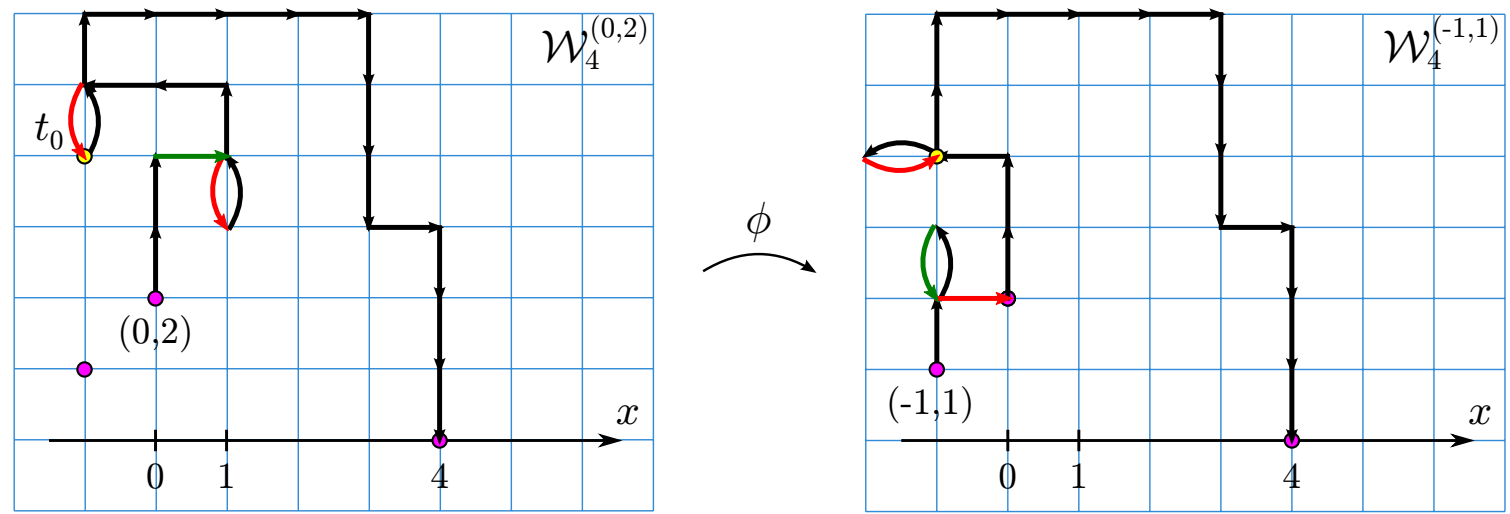

3.3. ábra: Kódolás a 2. esetben

2. eset: Ha $t_{0}$ a (3.10) feltételt teljesíti, akkor analóg módon járunk el (ld. 3.3. ábra): Ebben az esetben $W$ elsô $t_{0}$ lépése között a lefelé és a jobbra lépéseket 
cseréljük meg (a többi lépés változatlanul hagyásával); így kapjuk $\phi(W)$-t, melyet a $(-1,1)$ pontból indítunk, és $\mathcal{W}_{k}^{(-1,1)}$-beli séta lesz. Ugyanis az 1. esethez hasonlóan könnyen látható, hogy $\phi(W)$ egybeesik $W$-vel a $t_{0}$-adik lépés után. A $\phi(W)_{\leq t_{0}}$ szakasz pozitivitása pedig abból következik, hogy $t_{0}$ definíciója szerint $t \leq t_{0}$ esetén $\rightarrow_{t} \leq \uparrow_{t}$ áll fenn $W$-ben, amiból $\phi(W)$-re a kívánt $\downarrow_{t}^{\phi} \leq \uparrow_{t}^{\phi}$ adódik a $\downarrow / \rightarrow$ lépéscserék után. Megjegyezzük, hogy „első próbálkozásunk” éppen az imént definiált $\phi$ kódolás végrehajtása volt azokra a speciális sétákra, melyekre $t_{0}=1$.

A lemma bizonyításához már csak azt kell belátni, hogy $\phi$ injektív. Ehhez válasszunk egy tetszóleges $W^{\prime} \in \mathcal{W}_{k}^{(1,1)} \cup \mathcal{W}_{k}^{(-1,1)}$ sétát, melyre megmutatjuk, hogy legfeljebb egy ôse lehet. Ha $W^{\prime} \in \mathcal{W}_{k}^{(1,1)}$, akkor ezt a sétát csak az 1 . esetnek megfelelő átalakítással kaphatjuk meg. Egy 1. eset szerint kódolt $W$ sétához tartozó $t_{0}$ érték kiolvasható $\phi(W)$-ból $\phi$ definíciója alapján: $t_{0}$ a legkisebb olyan $t$, amelyre $\uparrow_{t}^{\phi}=\rightarrow_{t}^{\phi}+1$ teljesül $\phi(W)$-ben; ez $t_{0}$ definíciója és a $t_{0}$-adik lépésig tartó $\rightarrow / \downarrow$ lépéscserék alapján nyilvánvaló. Tehát $W^{\prime}$ ôse nem lehet más, mint az a séta, amelyet $W^{\prime}$-ból kapunk oly módon, hogy a fentiek szerint meghatározott $t_{0}$ idópontig megcseréljük a felfelé és jobbra lépéseket. Persze előfordulhat, hogy ilyen $t_{0}$ nem létezik $W^{\prime}$-höz (ekkor biztosan nincs ôse), illetve azt sem ellenóriztük, hogy ha $t_{0}$ létezik, akkor az egyetlen lehetséges ôs valóban $\mathcal{W}_{k}^{(0,2)}$-ban van-e, de az világos, hogy legfeljebb egy ôs lehet. Hasonlóan járhatunk el akkor is, ha $W^{\prime} \in \mathcal{W}_{k}^{(-1,1)}$. Ezzel $\phi$ injektivitását, és így a teljes lemmát, valamint a belőle következô 3.1. Tételt is igazoltuk.

Megjegyzés. A fenti bizonyítás alapján úgy túnhet, hogy $\phi$ kódolásunk nehezen vizualizálható. Ezért megjegyezzük, hogy például az 1. esetben definiált séta-transzformáció a következôképpen is megfogalmazható: $W$-nek valójában csak a felfelé és jobbra lépéseivel foglalkozunk, és az ezen lépésekból (a $W$-beli sorrend megtartásával) nyert $W_{\uparrow, \rightarrow}$ útnak az $y=x+1$ egyenessel vett elsố metszéspontjáig tartó

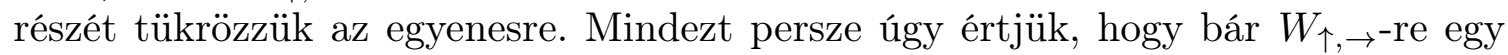
$(0,2)$ pontból induló sétaként gondolunk (amikor az $y=x+1$ egyenesre való tükrö-

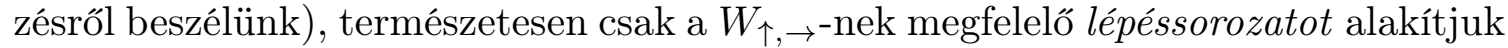
át $W$-ben, $W$ többi lépését fixen hagyva (vö. 3.2. ábra). A 2. eset kódolása hasonlóan fogalmazható át; ebben az esetben a jobbra és lefelé lépések által alkotott utat tükrözzük az $y=-x+1$ egyenesre. Tehát a két eset kódolása valójában egy-egy standard tükrözéses gondolat (például a Dyck-utak összeszámlálása is hasonló módon kézenfekô), mely szemléletben $\phi$ injektivitása nyilvánvaló. Konstrukciónk nemtriviális része az, ahogy ez a két tükrözés ,összeáll” egy $\mathcal{W}_{k}^{(0,2)} \rightarrow \mathcal{W}_{k}^{(1,1)} \cup \mathcal{W}_{k}^{(-1,1)}$ leképezéssé. $\diamond$

Végezetül kiemeljük, hogy a 3.2. Lemmát bizonyító injektív leképezésünk fixen hagyja a balra lépéseket. Ez azt jelenti, hogy a lemma következố erôsítése is igaz: Tetszóleges $k \in \mathbb{Z}, l \in \mathbb{N}$ és $S \subseteq\{1, \ldots, l-1\}$ esetén

$$
\left|\mathcal{W}_{k}^{(0,2)}[l ; S]\right| \leq\left|\mathcal{W}_{k}^{(1,1)}[l ; S]\right|+\left|\mathcal{W}_{k}^{(-1,1)}[l ; S]\right|
$$


ahol a $\mathcal{W}[l ; S]$ azon $\mathcal{W}$-beli, $l$ hosszú séták halmazát jelöli, melyekben a balra lépések pozícióinak halmaza éppen $S$. Az állításban szereplő séták száma explicit módon meghatározható zárt alakban, mindhárom sétatípusra: A balra lépések pozíciói adottak; $|S|, k$ és $l$ ismeretében a jobbra lépések, és így a „függóleges” lépések száma is adott; az utolsó lépés mindig lefelé lépés; a függóleges lépések egy olyan utat alkotnak (az elốzô fejezet szerinti értelemben), melyek a 2 (illetve 1) magasságról indulva az utolsó lépéssel lépnek először az $x$-tengelyre; más feltétel nincs. (A függóleges lépések által alkotott lehetséges utak száma meghatározható, ez az ismert „ballot problem” [23], amely mindhárom sétahalmaz esetén egy-egy Catalanszámhoz vezet. Tehát a függóleges és jobbra lépések összes lehetséges sorrendjének figyelembevételével a (3.11)-beli $\mathcal{W}[l ; S]$ halmazok elemszáma kiszámolható.) A kapott számosságokra elemi számolással is ellenórizhető a (3.11) egyenlőtlenség, amely a 3.2. Lemma egy újabb bizonyítását adja. (A részletek kidolgozását az olvasóra bízzuk.)

\subsection{Magasabbról indított véletlen séták}

A 3.1. Tétel ismeretében természetes módon vetôdik fel annak vizsgálata, hogy a $(0,1)$ pontnál magasabbról indított véletlen séták esetén mit mondhatunk a $\left(p_{k}^{(0, h)}\right)_{k=0}^{\infty}$ sorozat konvexitásáról. A kérdést Totik Vilmos fogalmazta meg. A továbbiakban bemutatom a témában elért, Szalai Attilával közös eredményeinket, majd ismertetem a folytonos eset alapján megfogalmazott célokat, egy kombinatorikus módon megoldatlan eredménnyel együtt, amely módszerünk korlátaira is rávilágít. Az alfejezet egésze a Szalai Attilával közös, 2014-ben elfogadott [17] publikáción alapul.

Az alfejezet fô eredménye a következô:

3.3. Tétel. Jelölje $p_{k}^{h}$ annak a valószínúségét, hogy a $(0, h)$ pontból induló $\mathbb{Z}^{2}$-beli véletlen séta a $(k, 0)$ pontban lép elöször az $x$-tengelyre, és legyen $h \geq 2$ rögzített. Ekkor a $\left(p_{k}^{h}\right)_{k=h-2}^{\infty}$ sorozat konvex, vagyis $p_{k}^{h} \leq \frac{1}{2}\left(p_{k-1}^{h}+p_{k+1}^{h}\right)$ teljesül $k \geq h-1$ esetén.

Bizonyítás. Használjuk az elôzô alfejezet jelöléseit (tehát például $p_{k}^{h}=p_{k}^{(0, h)}$ ). A realizáló séták elsô lépését vizsgálva, (3.2) analógiájára most a

$$
p_{k}^{h}=\frac{1}{4} p_{k}^{h-1}+\frac{1}{4} p_{k}^{h+1}+\frac{1}{4} p_{k}^{(1, h)}+\frac{1}{4} p_{k}^{(-1, h)}=\frac{1}{4} p_{k}^{h-1}+\frac{1}{4} p_{k}^{h+1}+\frac{1}{4} p_{k-1}^{h}+\frac{1}{4} p_{k+1}^{h}
$$

összefüggéshez jutunk, ahol felhasználtuk, hogy $p_{k}^{(1, h)}=p_{k-1}^{h}$ és $p_{k}^{(-1, h)}=p_{k+1}^{h}$. Tehát a tételben szereplő konvexitási egyenlótlenséghez azt kell megmutatni, hogy $k \geq h-1$ esetén

$$
p_{k}^{h-1}+p_{k}^{h+1} \leq p_{k-1}^{h}+p_{k+1}^{h} .
$$

Ehhez $p_{k-1}^{h}+p_{k+1}^{h}=p_{k}^{(1, h)}+p_{k}^{(-1, h)}$, valamint (3.6) ismételt figyelembevételével elegendő belátni, hogy létezik hossztartó $\mathcal{W}_{k}^{(0, h-1)} \cup \mathcal{W}_{k}^{(0, h+1)} \rightarrow \mathcal{W}_{k}^{(1, h)} \cup \mathcal{W}_{k}^{(-1, h)}$ 
injektív leképezés. Ezt a következô lemmában tárgyaljuk. (Késôbb kiszámoljuk a $\mathcal{W}_{k_{2}}^{\left(k_{1}, h\right)}$ halmazok elemszámának pontos értékét is - lásd 3.8. Következmény -, ennek ismeretében bizonyításunk „számolással” is befejezhető.)

3.4. Lemma. Legyen adott $h \geq 2$ és $k \geq h-1$. Ekkor létezik hossztartó, injektív $\mathcal{W}_{k}^{(0, h-1)} \cup \mathcal{W}_{k}^{(0, h+1)} \rightarrow \mathcal{W}_{k}^{(1, h)} \cup \mathcal{W}_{k}^{(-1, h)}$ leképezés. Vagyis tetszóleges $l \in \mathbb{N}$ esetén

$$
\left|\mathcal{W}_{k}^{(0, h-1)}[l]\right|+\left|\mathcal{W}_{k}^{(0, h+1)}[l]\right| \leq\left|\mathcal{W}_{k}^{(1, h)}[l]\right|+\left|\mathcal{W}_{k}^{(-1, h)}[l]\right|
$$

Bizonyítás. Megadunk egy alkalmas $\phi$ leképezést. Tekintsünk egy tetszóleges $W$ sétát a $\mathcal{W}_{k}^{(0, h-1)} \cup \mathcal{W}_{k}^{(0, h+1)}$ halmazból. Legyen $P$ az elsó olyan rácspont, ahol $W$ rálép a $(h, 0),(h, 2 h),(-h, 2 h)$ és $(-h, 0)$ csúcsok által meghatározott négyzet valamelyik oldalára vagy átlójára. (Ilyen $P$ pont nyilván létezik.) Ez a $P$ pont két részre osztja a $W$ sétát; jelölje $W_{-}$a kezdôponttól a $P$ pontig (pontosabban annak elsố meglátogatásáig) tartó szakaszt, és jelölje $W_{+}$a séta hátralévố részét.

Ha $W \in \mathcal{W}_{k}^{(0, h-1)}$, akkor $P$ az egyik átló pontja, mert a $(0, h),(-h, 0)$ és $(h, 0)$ csúcsok által meghatározott „alsó” háromszöget metszi elöször a $(0, h-1)$ belsố pontból induló, $x$-tengelyen végzôdő $W$ séta, és ez a metszéspont nem lehet az $x$-tengelyen a $k \geq h-1$ feltétel miatt. Ebben az esetben $\phi(W)$ legyen az a séta, amelyet úgy kapunk $W$-ból, hogy $W_{-}$-t tükrözzük arra a négyzetátlóra, amelyik tartalmazza $P$-t, és $W_{+}$-t változatlanul hagyjuk, lásd 3.4. ábra. (Ha $P=(0, h)$, akkor válasszuk a pozitív meredekségú átlót a tükrözéshez.) Világos, hogy ekkor $\phi(W)$ kezdôpontja $(-1, h)$ vagy $(1, h)$ lesz, és mivel $W_{-}$a négyzeten belül haladva jutott el a $P$ pontig, ezért $\phi(W)$-nek a $W_{-}$-ból tükrözéssel nyert szakasza is így fog eljutni oda; onnantól pedig $\phi(W)$ egybeesik $W$-vel. Tehát $\phi(W)$ is pozitív séta lesz, vagyis ebben az esetben $\phi(W) \in \mathcal{W}_{k}^{(1, h)} \cup \mathcal{W}_{k}^{(-1, h)}$ teljesül.

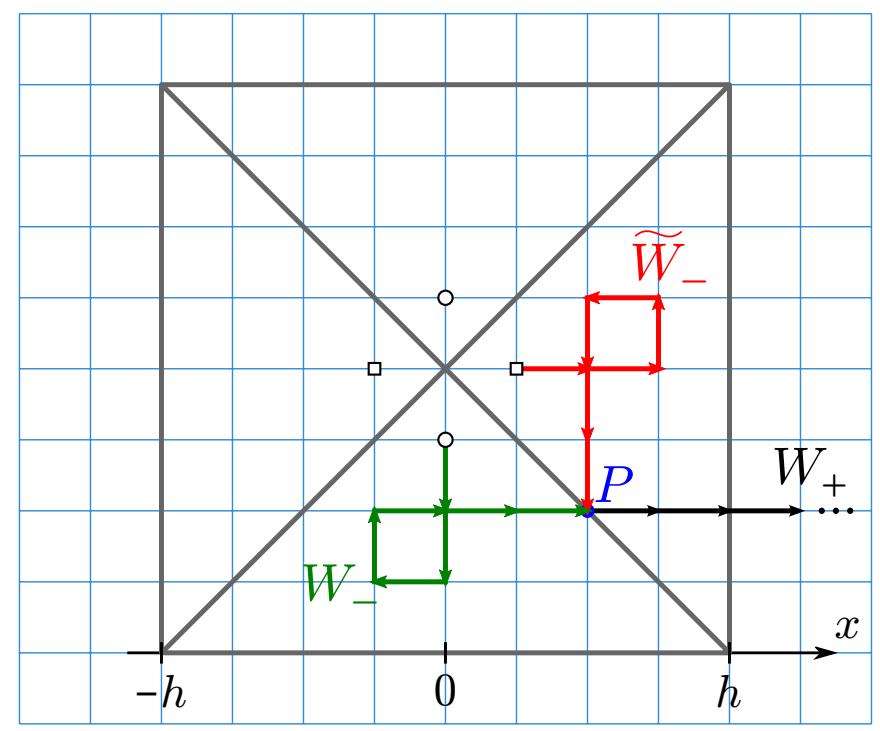

3.4. ábra: A kódolás menete, ha $P$ valamelyik négyzetátlón helyezkedik el 
Ha $W \in \mathcal{W}_{k}^{(0, h+1)}$, akkor a séta a $(0, h),(h, 2 h)$ és $(-h, 2 h)$ csúcsok által meghatározott „felsô”" háromszöget metszi először. Amennyiben $P$ valamelyik átlón helyezkedik el, ugyanúgy járunk el, mint az eloobb, és hasonlóan kapjuk, hogy ez jó definíció, azaz ily módon $W$-hez $\mathcal{W}_{k}^{(1, h)} \cup \mathcal{W}_{k}^{(-1, h)}$-beli sétát rendelünk. Amennyiben $P$ a négyzet felsố oldalán helyezkedik el, tehát ha $P=(m, 2 h)$, ahol $m \in$ $\{-(h-2), \ldots, h-2\}$, akkor a soron következő 3.5. Lemmára támaszkodunk, mely szerint létezik hossztartó $\psi_{m}: \mathcal{W}_{k}^{(m, 2 h)} \rightarrow \mathcal{W}_{k}^{(h, h+m)} \cup \mathcal{W}_{k}^{(-h, h-m)}$ injekció. (A továbbiakban ezt az injekciót röviden $\psi$-vel jelöljük.) A $W_{+} \in \mathcal{W}_{k}^{(m, 2 h)}$ séta $\psi\left(W_{+}\right)$ képének kezdôpontja, $(h, h+m)$ vagy $(-h, h-m)$, megkapható $P$ valamelyik négyzetátlóra való tükrözésével. (A 3.5. ábrán $P^{\prime}$-vel, illetve $P^{\prime \prime}$-vel jelöltük a két szóban forgó pontot.) Tehát $\phi(W)$-t definiálhatjuk a $\widetilde{W}_{-}$és $\psi\left(W_{+}\right)$séták konkatenációjaként, ahol $\widetilde{W}_{-}$a $W_{-}$séta alkalmas négyzetátlóra való tükörképe. (Azt a tükrözést választjuk, mely $P$-t, a $W_{-}$séta végpontját, $\psi\left(W_{+}\right)$kezdôpontjába viszi, lásd 3.5. ábra.) Mivel $\widetilde{W}_{-}$egy $x$-tengely felett (a négyzetben) haladó, $(-1, h)$ vagy $(1, h)$ kezdőpontú séta, és $\psi\left(W_{+}\right)$egy $(k, 0)$ pontban végződő pozitív séta, ezért $\phi(W) \in \mathcal{W}_{k}^{(1, h)} \cup \mathcal{W}_{k}^{(-1, h)}$ ismét fennáll.

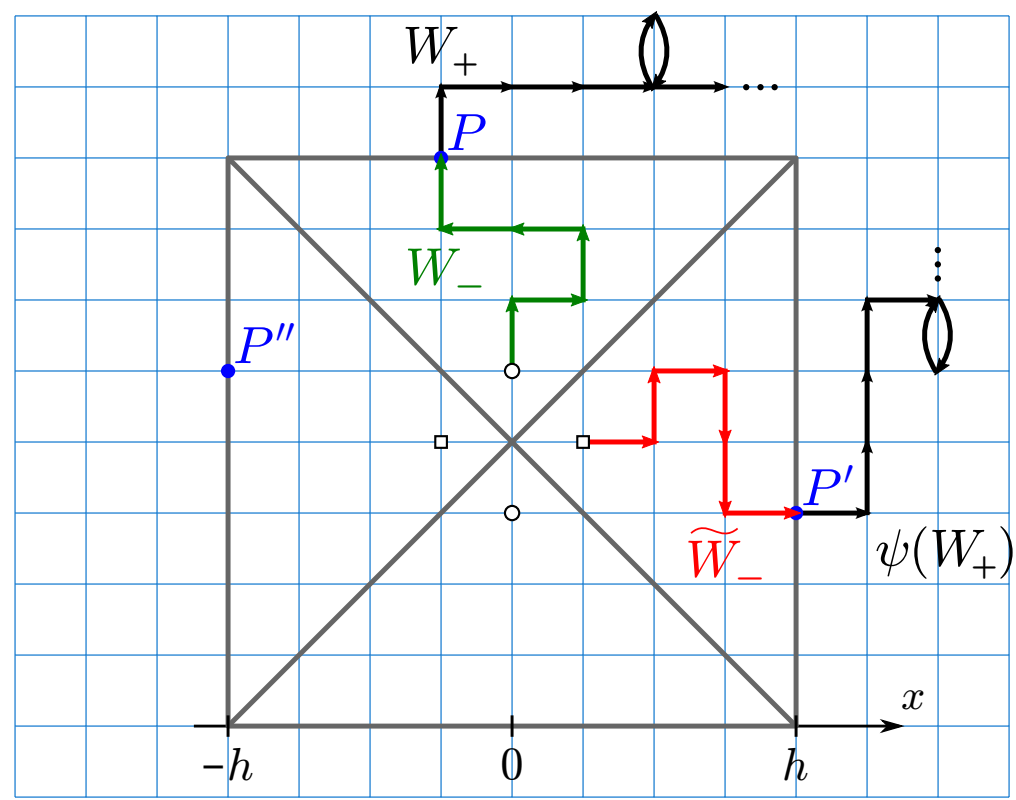

3.5. ábra: A kódolás menete, ha $P$ a négyzet felsố oldalán helyezkedik el

Leképezésünk hossztartása nyilvánvaló, már csak az injektivitás meggondolása maradt hátra. Mindegyik alesetben úgy definiáltuk $W$ képét, hogy egy-egy átalakítást hajtottunk végre a $W_{-}$és $W_{+}$részsétákon ( $W_{-}$-t tükröztük, $W_{+}$-ot pedig változatlanul hagytuk, vagy $\psi\left(W_{+}\right)$-ra cseréltük). Az átalakítások után kapott részsétákat rendre $\widehat{W}_{-}$-szal és $\widehat{W}_{+}$-szal jelölve, konstrukciónkból adódóan a $\phi(W)$ képből kiolvasható, hogy $\phi(W)$-ben meddig tart a $\widehat{W}_{-}$szakasz: Addig a $P_{\phi(W)}$ pontig, ahol $\phi(W)$ először lép az eddig is tekintett négyzet valamelyik átlójára vagy oldalára. Könnyen ellenôrizhetô, hogy tetszóleges $V$ és $W$ sétákra $V_{-} \neq W_{-}$ 
esetén $\widehat{V}_{-} \neq \widehat{W}_{-}$, illetve $V_{+} \neq W_{+}$esetén $\widehat{V}_{+} \neq \widehat{W}_{+}$áll fenn (a tükrözések és a $\psi_{m}$ leképezések injektivitása miatt). Ezekből következik, hogy egy tetszóleges $W^{\prime} \in \mathcal{W}_{k}^{(1, h)} \cup \mathcal{W}_{k}^{(-1, h)}$ sétának legfeljebb egy ôse lehet: A $W^{\prime}$ sétához tartozó $P_{W^{\prime}}$ pont kijelöli a keresett $W$ ös(ök)höz tartozó $\widehat{W}_{-}$és $\widehat{W}_{+}$szakaszokat $W^{\prime}$-ben, amiből az iménti ,injektivitási tulajdonság” alapján kapjuk, hogy legfeljebb egy $W_{-}$és $W_{+}$, azaz legfeljebb egy $W$ ôs létezhet. Ezzel $\phi$ injektivitását igazoltuk.

Most rátérünk a bizonyításban megígért lemmára, amelynek speciális esete a $(0,1)$ pontból indított véletlen sétákra vonatkozó fólemma, a 3.2. Lemma (amely a $h=1, m=0$ esetnek felel meg). Nem egyszerúen csak általánosítjuk korábbi lemmánk állítását, a bizonyítás alapgondolatát is átültetjük az általánosabb környezetbe, ezért ezt a bizonyítást kevésbé részletesen tárgyaljuk.

3.5. Lemma. Tetszóleges olyan $h, k, m$ egészekre, melyekre $h \geq 1$ és $-h<m<h$, létezik hossztartó $\mathcal{W}_{k}^{(m, 2 h)} \rightarrow \mathcal{W}_{k}^{(h, h+m)} \cup \mathcal{W}_{k}^{(-h, h-m)}$ injekció.

Bizonyítás. Megadunk egy ilyen $\psi$ leképezést. Legyen $W \in \mathcal{W}_{k}^{(m, 2 h)}$ tetszóleges. Használjuk a 3.2. Lemma bizonyításában bevezetett jelöléseket: $W_{\leq t}$ jelöli a $W$ elsố $t$ lépése által alkotott sétát, és rendre $\uparrow_{t}, \downarrow_{t}$ és $\rightarrow_{t}$ jelöli a felfelé, lefelé és jobbra lépések számát $W_{\leq t}$-ben. Legyen $t_{0}$ legkisebb olyan $t$ természetes szám (,idôpont”), amelyre a következók valamelyike teljesül:

$$
\begin{aligned}
\rightarrow_{t} & =\uparrow_{t}+h-m, \\
\downarrow_{t} & =\rightarrow_{t}+h+m .
\end{aligned}
$$

Mivel $h-m>0$ és $h+m>0$, kezdetben $(t=0$ esetén) mindkét feltételben a bal oldal szigorúan kisebb, mint a jobb oldal. A feltételekben a két oldal különbsége legfeljebb 1-gyel változhat $t$ értékének 1-gyel való növelésével, ezért a két egyenlôségjel helyett írhatnánk $\geq$ jeleket is a feltételekben, azzal ugyanazt a $t_{0}$ értéket definiálnánk. A $t=|W|-1$ időpontban $\rightarrow_{t} \geq \uparrow_{t}+h-m$ vagy $\downarrow_{t} \geq \rightarrow_{t}+h+m$ teljesül, ellenkező esetben arra jutnánk, hogy

$$
\downarrow_{t} \leq \rightarrow_{t}+h+m-1 \leq\left(\uparrow_{t}+h-m-1\right)+h+m-1=\uparrow_{t}+2 h-2,
$$

ami azonban lehetetlen, ugyanis ebben az időpontban a $W$ séta a $(k, 1)$ pontban tartózkodik (közvetlenül az $x$-tengelyre lépés elótt), azaz a kiinduló $2 h$ magasságnál $(2 h-1)$-gyel alacsonyabban, más szóval $\downarrow_{t}=\uparrow_{t}+2 h-1$. Kaptuk tehát, hogy $t_{0}$ létezik (és $t_{0} \leq|W|-1$ ).

Ha $t_{0}$ a (3.16) feltételt elégíti ki (1. eset), akkor $\psi(W)$ legyen az a $(h, h+m)$ pontból induló séta, amelyet úgy kapunk $W$-ból, hogy $W$ elsô $t_{0}$ lépése között megcseréljük a jobbra és felfelé lépéseket. Ha $t_{0}$ a (3.17) feltételt elégíti ki (2. eset), akkor $\psi(W)$ legyen az a $(-h, h-m)$ pontból induló séta, amelyet úgy kapunk $W$ ból, hogy $W$ elsố $t_{0}$ lépése között megcseréljük a lefelé és jobbra lépéseket. (A két feltétel közül csak az egyiket elégíti ki $t_{0}$.) Egyszerúen ellenőrizhetô, hogy $\psi(W)$ mindkét esetben egybeesik $W$-vel a $t_{0}$-adik lépés után. A $\psi(W)_{\leq t_{0}}$ szakasz pedig 
végig az $x$-tengely fölött halad, mert $t_{0}$ definíciója miatt a $t \leq t_{0}$ értékekre az 1. esetben $\downarrow_{t}<\rightarrow_{t}+h+m$ adódik, és így a $\rightarrow / \uparrow$ lépéscserék miatt a bizonyítandó $\downarrow_{t}^{\psi}<\uparrow_{t}^{\psi}+h+m$; a 2 . esetben pedig $\rightarrow_{t}<\uparrow_{t}+h-m$ és a $\downarrow / \rightarrow$ lépéscserék figyelembevételével kapjuk a bizonyítandó $\downarrow_{t}^{\psi}<\uparrow_{t}^{\psi}+h-m$ egyenlőtlenséget. Ezek alapján $\psi(W) \in \mathcal{W}_{k}^{(h, h+m)} \cup \mathcal{W}_{k}^{(-h, h-m)}$, tehát $\psi$ jóldefiniált. Az injektivitás a 3.2. Lemma bizonyításában látottakhoz hasonlóan könnyen meggondolható, a hossztartás pedig nyilvánvaló.

Most a 3.3. Tétel lehetséges élesítéseit vizsgáljuk meg. Egy $(0, h)$ pontból induló $\mathbb{Z} \times \mathbb{Z}$-beli véletlen sétára tekinthetünk úgy is, mint egy $(0,1)$ pontból induló véletlen sétára a $h^{-1} \mathbb{Z} \times h^{-1} \mathbb{Z}$ négyzetrácson $\left(h^{-1}\right.$ arányú skálázás után). Ismert, hogy a sík egy rögzített pontjából induló $h^{-1} \mathbb{Z} \times h^{-1} \mathbb{Z}$-beli véletlen séták a négyzetrács finomításával (vagyis $h^{-1} \rightarrow 0$ esetén) a 2-dimenziós Brown-mozgáshoz tartanak; ennek szabatos tárgyalása megtalálható [14] 3. fejezetében. Az a véletlen pont (abszcissza), ahol a $(0,1)$ pontból induló 2-dimenziós Brown-mozgás elôször metszi az $x$-tengelyt, standard Cauchy-eloszlást követ [15; 2.37. tétel], melynek sûrûségfüggvénye $\frac{1}{\pi\left(1+x^{2}\right)}$. A $(0, h)$ pontból induló $\mathbb{Z}^{2}$-beli véletlen sétára $h^{-1}$ arányú skálázás, majd „visszaskálázás” után tekintve, az eddigiek alapján azt kapjuk, hogy tetszóleges rögzített $x$-re

$$
\lim _{h \rightarrow \infty} \sum_{k=-\infty}^{\lfloor h x\rfloor} p_{k}^{h}=\int_{-\infty}^{x} \frac{1}{\pi\left(1+t^{2}\right)} \mathrm{d} t .
$$

Ennek precíz bizonyítása megtalálható a [27] monográfia 3. fejezetében (a 15. alfejezetben). Mivel az $\frac{1}{\pi\left(1+x^{2}\right)}$ súrúségfüggvény a $\left(0, \frac{1}{\sqrt{3}}\right)$ intervallumon konkáv, az $\left(\frac{1}{\sqrt{3}}, \infty\right)$ intervallumon konvex, a határeloszlás ismeretében azt sejthetjük, hogy nagy $h$ értékekre a $\left(p_{k}^{h}\right)_{k=0}^{K}$ sorozat konkáv, a $\left(p_{k}^{h}\right)_{k=K}^{\infty}$ sorozat konvex valamely $K \sim \frac{h}{\sqrt{3}}$ küszöbértékre.

A 3.3. Tétel után a kézenfekvő következő lépés az lehetne, hogy bizonyítjuk a konkávitást a $k \leq \alpha h$ intervallumon, valamely $\alpha>0$ konstansra, ezzel igazolva, hogy tételünk konstans szorzó erejéig éles. Úgy gondoljuk, hogy a bizonyított konvexitási intervallum alsó határa, $h-2$ is javítható $\beta h$-ra, 1-nél kisebb $\beta$ konstanssal. Az alábbi tételból következik, hogy eddigi módszerünkkel nem érünk célt. (Erre még visszatérünk a tételt követően.)

3.6. Tétel. Legyen $h \geq 2$ és $k$ rögzített, valamint jelölje rendre $V_{l}$, illetve $F_{l}$ azon $l$ hosszú, $\mathcal{W}_{k}^{(0, h)}$-beli séták számát, amelyek kezdô lépése vízszintes (balra vagy jobbra lépés), illetve függóleges (felfelé vagy lefelé lépés). Ekkor

$\circ l=h^{2}-k^{2}$ esetén $V_{l}=F_{l}$;

○ $l \geq h^{2}-k^{2}$ esetén $V_{l} \geq F_{l}$;

○ $l \leq h^{2}-k^{2}$ esetén $V_{l} \leq F_{l}$.

Továbbá, ha $l \neq h^{2}-k^{2}$, akkor $V_{l}=F_{l}$ csak $V_{l}=F_{l}=0$ esetén fordulhat eló, azaz csak akkor, ha l olyan, hogy $\mathcal{W}_{k}^{(0, h)}[l]=\emptyset$. 
Bizonyításunk a következô lemmán alapul, melynek segítségével $V_{l}$ és $F_{l}$ explicit módon felírható zárt alakban. Ez az elemi lemma nem meglepô módon korábban is ismert volt (ld. például a [4] és [10] cikkeket), mégis vázoljuk a bizonyítását a gondolatmenet eleganciája miatt.

3.7. Lemma. Legyen $b, d>0$, és jelölje $W_{(c, d)}^{(a, b)}[n]$ az n hosszú $(a, b) \rightsquigarrow(c, d)$ pozitív séták számát $\mathbb{Z}^{2}-n$. Ekkor

$$
W_{(c, d)}^{(a, b)}[n]=\left(\begin{array}{c}
n \\
r
\end{array}\right)\left(\begin{array}{c}
n \\
s
\end{array}\right)-\left(\begin{array}{c}
n \\
r+b
\end{array}\right)\left(\begin{array}{c}
n \\
s-b
\end{array}\right)
$$

ahol éltünk az $r=\frac{1}{2}(n-a-b+c+d)$ és $s=\frac{1}{2}(n-a+b+c-d)$ jelölésekkel. (Az $\left(\begin{array}{l}n \\ t\end{array}\right)$ binomiális együtthatót természetesen 0 -nak definiáljuk, ha $t \notin\{0, \ldots, n\}$.)

Bizonyítás. Az elsố tag, $\left(\begin{array}{l}n \\ r\end{array}\right)\left(\begin{array}{l}n \\ s\end{array}\right)$, az összes $(a, b) \rightsquigarrow(c, d)$ séták száma $\mathbb{Z}^{2}$-n. Ennek belátásához a standard koordinátarendszer helyett $45^{\circ}$-kal elforgatott koordinátarendszerben dolgozunk. A $\mathbb{Z}^{2}$-beli séták 4 megengedett lépése egyértelmúen felírható $\gamma \cdot(1 / 2,1 / 2)+\delta \cdot(1 / 2,-1 / 2)$ alakban, ahol $\gamma, \delta \in\{-1,1\}$. Egy $n$ hosszú $(a, b) \rightsquigarrow(c, d)$ séta lépéssorozatában ezek a $\gamma_{i}$ és $\delta_{i}$ együtthatók tetszólegesen megválaszthatók \pm 1 -nek $(i=1, \ldots, n)$, csak annak kell teljesülnie, hogy az $(a, b)$ kezdôpont és $(c, d)$ végpont közötti $(c-a, d-b)$ összelmozdulás-vektort adja ki a lépések összege. Könnyen ellenơrizhetô, hogy ez két feltételhez vezet: Ahhoz, hogy a $\gamma_{i}$ együtthatók között pontosan $r$ darab 1-es, a $\delta_{i}$ együtthatók között pedig pontosan $s$ darab 1-es legyen. Tehát az együtthatósorozat megválasztására $\left(\begin{array}{l}n \\ r\end{array}\right)\left(\begin{array}{l}n \\ s\end{array}\right)$ lehetôség van, ahogy állítottuk. (Még nem használtuk $b$ és $d$ pozitivitását, ez a zárt alak bármely $a, b, c, d$ egészekre érvényes.) A „rossz” sétákat számolja meg (3.18) második tagja: Azon $(a, b) \rightsquigarrow(c, d)$ séták száma, amelyek rálépnek az $x$-tengelyre, megegyezik az összes $(a,-b) \rightsquigarrow(c, d)$ séták számával. (Bijekciót kapunk a két halmaz között, ha a rossz séták elsô $x$-tengelymetszetig tartó szakaszát tükrözzük az $x$-tengelyre.) Az összes $(a,-b) \rightsquigarrow(c, d)$ séták száma az előzőek alapján $\left(\begin{array}{c}n \\ r+b\end{array}\right)\left(\begin{array}{c}n \\ s-b\end{array}\right)$, ezzel a (3.18) zárt alak helyességét igazoltuk.

A 3.6. Tétel bizonyítása. (Vázlat.) Az első és utolsó lépések elhagyása mutatja, hogy

$$
\begin{aligned}
V_{l} & =W_{(k, 1)}^{(-1, h)}[l-2]+W_{(k, 1)}^{(1, h)}[l-2], \\
F_{l} & =W_{(k, 1)}^{(0, h-1)}[l-2]+W_{(k, 1)}^{(0, h+1)}[l-2],
\end{aligned}
$$

a 3.7. Lemma jelöléseit használva. Ebból (3.18) szerint $V_{l}$ és $F_{l}$ kifejezhető binomiális együtthatókkal. Ezután a tételben szereplő állítások mindegyike ellenôrizhetô fárasztó, de elemi számolással. A számolás részleteit mellőzzük.

Megjegyzés. Meglepőnek találjuk, hogy a 3.6. Tételben szereplő kritikus hosszra szép, egész érték adódott, $h^{2}-k^{2}$. Ennek nem látjuk szemléletes kombinatorikus okát.

A tétel utolsó állításához kiegészítésként megjegyezzük, hogy $\mathcal{W}_{k}^{(0, h)}[l]$ pontosan akkor nem üres, ha $l$ ugyanolyan paritású, mint $h+k$, továbbá $l \geq h+|k|$. $\diamond$ 
Figyelembe véve, hogy $\left|\mathcal{W}_{k_{2}}^{\left(k_{1}, h\right)}[l]\right|=W_{\left(k_{2}, 1\right)}^{\left(k_{1}, h\right)}[l-1]$, a 3.7. Lemma megadja az alfejezetben tekintett $\mathcal{W}$ halmazok számosságát:

3.8. Következmény. $A \mathcal{W}_{k_{2}}^{\left(k_{1}, h\right)}[l]$-beli séták száma, $k=k_{2}-k_{1}$ jelöléssel élve,

$$
\left(\begin{array}{c}
l-1 \\
(l+k-h) / 2
\end{array}\right)\left(\begin{array}{c}
l-1 \\
(l+k+h-2) / 2
\end{array}\right)-\left(\begin{array}{c}
l-1 \\
(l+k-h-2) / 2
\end{array}\right)\left(\begin{array}{c}
l-1 \\
(l+k+h) / 2
\end{array}\right) .
$$

A következmény felhasználásával eddigi tételeinkre „számolós” bizonyítások is adhatók, így például a 3.2. Lemmára, és a belőle következő 3.1. Tételre is.

Ahogy elórevetítettük, a 3.6. Tétel valóban azt mutatja, hogy a $\left(p_{k}^{h}\right)_{k \geq 0}$ sorozat konvexitásával kapcsolatos további eredményekhez új megközelítésre van szükség. Világos, hogy a tételben szereplő számosságok valójában az alfejezet fólemmájában, a 3.4. Lemmában szereplő számosságok (tekintsünk el a séták elsô lépésétôl):

$$
\begin{aligned}
& F_{l}=\left|\mathcal{W}_{k}^{(0, h-1)}[l-1]\right|+\left|\mathcal{W}_{k}^{(0, h+1)}[l-1]\right|, \\
& V_{l}=\left|\mathcal{W}_{k}^{(1, h)}[l-1]\right|+\left|\mathcal{W}_{k}^{(-1, h)}[l-1]\right| .
\end{aligned}
$$

(Tehát a tételból azonnal következik a 3.4. Lemma, ugyanis $k \geq h-1$ esetén $h^{2}-k^{2} \leq k+h$, tehát $F_{l} \leq V_{l}$ áll fenn minden $l$ hosszra, mert $(k+h)$-nál kisebb $l$-ekre nyilván $F_{l}=V_{l}=0$, ha pedig $l \geq k+h$, akkor egyben $l \geq h^{2}-k^{2}$ is, és így hivatkozhatunk a tételre.) Azonban $0 \leq k<h-1$ esetén $h^{2}-k^{2}>h+k$, ezért ekkor az $l$ hossz változtatásával $V_{l}>F_{l}$ és $V_{l}<F_{l}$ is elófordulhat. Ugyanis a 3.6. Tétel szerint $V_{l}>F_{l}$ mindig teljesül, ha $l$ elég nagy, és megfelelö paritású (azaz ha $l$ a kritikus hossznál nagyobb, és olyan, hogy $\left.\mathcal{W}_{k}^{(0, h)}[l] \neq \emptyset\right)$; továbbá $V_{l}<F_{l}$ teljesül például az $l=h+k$ hosszra ( $l$ ekkor rövidebb, mint a $h^{2}-k^{2}$ kritikus hossz, és $\mathcal{W}_{k}^{(0, h)}[l] \neq \emptyset$, mert például tartalmazza a $k$ jobbra lépésból, majd $l$ lefelé lépésból álló sétát). Ez azt jelenti, hogy $0 \leq k<h-1$ esetén sem a 3.4. Lemmában szereplő (3.13) egyenlőtlenség, sem annak az egyenlőtlenségjel megfordításával nyert változata nem igaz minden $l$ hosszra. Tehát a $p_{k}^{h} \leq \frac{1}{2}\left(p_{k-1}^{h}+p_{k+1}^{h}\right)$ konvexitási egyenlótlenség (3.12) ekvivalens alakját nem tudjuk becsülni a 3.4. Lemmával, ahogy eddig (azaz a benne szereplő valószínúségeket (3.6) szerint végtelen sorként felírva, majd tagonként igazolva az egyenlótlenséget). A konkávitásnak megfelelő fordított irányú egyenlőtlenségre ugyanez az érvelés mutatja módszerünk korlátait. Nem elég tehát a $p_{k}^{h}$ valószínúségekhez hozzájáruló sétákat az első $x$-tengelymetszetig tartó szakaszuk hossza szerint osztályozni, a $[0, h-2]$ intervallumon kifinomultabb megközelítés kell a $\left(p_{k}^{h}\right)_{k \geq 0}$ sorozat konvexitásvizsgálatához. Megjegyezzük, hogy a 3.8. Következményben meghatároztuk a $\left|\mathcal{W}_{k_{2}}^{\left(k_{1}, h\right)}[l]\right|$ számosságot, ezzel a (3.6) végtelen sort explicit módon is definiáltuk.

Zárásként egy, az elôzố tételhez hasonló, szintén meglepô lemmát közlünk, mely a 3.7. Lemma felhasználásával számolással igazolható. (Szemléletesebb kombinatorikus bizonyítást nem ismerünk.) 
3.9. Lemma. Legyen $h \geq 2$ és $k$ rögzített, valamint jelölje $J_{l}$ (illetve $L_{l}$ ) azon $l$ hosszú, $\mathcal{W}_{k}^{(0, h)}$-beli séták számát, amelyek kezdô lépése jobbra lépés (illetve lefelé lépés). Ekkor

○ $l=(h-k)(2 h-1)$ esetén $J_{l}=L_{l}$;

○ $l \geq(h-k)(2 h-1)$ esetén $J_{l} \geq L_{l}$;

○ $l \leq(h-k)(2 h-1)$ esetén $J_{l} \leq L_{l}$.

Továbbá, ha $l \neq(h-k)(2 h-1)$, akkor $J_{l}=L_{l}$ csak $J_{l}=L_{l}=0$ esetén fordulhat elô.

Megjegyzés. A lemma $k<0$ esetén is igaz, így függóleges tengelyre vonatkozó szimmetria alapján a balra, illetve lefelé lépésekkel kezdődő $\mathcal{W}_{k}^{(0, h)}$-beli séták száma is összehasonlítható a lemma segítségével, ebben az esetben a $(h+k)(2 h-1)$ kritikus hossz adódik. Az analóg balra/fel (és jobbra/fel) kezdő irányok összehasonlítása nyilvánvalóan visszavezethetô a $\mathcal{W}_{k}^{(-1, h+1)}$-beli sétákra vonatkozó jobbra/le (és a $\mathcal{W}_{k}^{(1, h+1)}$-beli sétákra vonatkozó balra/le) összehasonlításra, amelyet már megoldottunk, csak más koordinátázásban. A balra/jobbra, illetve fel/le összehasonlítások nem vezetnek érdekes problémákhoz; az elsô egyszerú, a második esetben pedig számítógépes vizsgálatok szerint jellemzóen nincs olyan hossz, amelyre a két fajta séták száma megegyezik. $\diamond$

\subsection{Analóg eredmények magasabb dimenziókban}

Ebben az alfejezetben eddigi eredményeinket kiterjesztjük magasabb dimenziókra is. A $\mathbb{Z}^{d}$-beli véletlen sétákra megvizsgáljuk az $x_{1}, \ldots, x_{d-1}$ koordinátatengelyek által kifeszített hipersíkkal vett elsố metszéspont eloszlásának szubharmonikusságát. Az alapesetet - a 3.10. Tételt - Totik Vilmos oldotta meg, melyet közös [18] cikkünkben publikáltunk; az általános esetre vonatkozó részeredmény - a 3.11. Tétel - teljesen hasonlóan igazolható, ezt Szalai Attilával közösen végeztük el [17]. Mindkét esetben síkbeli eredményeinkre vezetjük vissza a problémát.

Először a szükséges fogalmakat és jelöléseket tárgyaljuk. Az n-dimenziós tér standard bázisvektorait $\boldsymbol{e}_{\mathbf{1}}, \ldots, \boldsymbol{e}_{\boldsymbol{n}}$ jelöli a továbbiakban, ahol az $\boldsymbol{e}_{\boldsymbol{i}}$ vektor $i$-edik koordinátája 1, a többi 0 . Egy $\boldsymbol{k} \in \mathbb{Z}^{n}$ pontnak $2 n$ szomszédja van $\mathbb{Z}^{n}$-ben, az $N(\boldsymbol{k}):=\left\{\boldsymbol{k} \pm \boldsymbol{e}_{\boldsymbol{i}}: i=1, \ldots, n\right\}$ halmaz pontjai. A sorozatok konvexitásának alábbi általánosításával fogunk dolgozni:

Definíció. Azt mondjuk, hogy az $f: \mathbb{Z}^{n} \rightarrow \mathbb{R}$ diszkrét függvény (lokálisan) szubharmonikus a $\boldsymbol{k} \in \mathbb{Z}^{n}$ pontban, ha

$$
f(\boldsymbol{k}) \leq \frac{1}{2 n} \sum_{\boldsymbol{j} \in N(\boldsymbol{k})} f(\boldsymbol{j}) .
$$

Rögzítsünk egy tetszóleges $d \geq 2$ dimenziót. A $\mathbb{Z}^{d}$-beli sétákat a 2-dimenziós eset mintájára definiáljuk; egy pontból mindig valamelyik szomszédos pontra léphetünk, tehát egy lépés a $\pm \boldsymbol{e}_{\boldsymbol{i}}$ vektorok valamelyike lehet. $\mathrm{A} \mathbb{Z}^{d}$-beli véletlen séták 
lépései most is uniform módon, egymástól függetlenül kerülnek ki a $2 d$ lehetséges lépés közül. Adott $h \in \mathbb{N}$ és $\boldsymbol{k}=\left(k_{1}, \ldots, k_{d-1}\right) \in \mathbb{Z}^{d-1}$ esetén legyen $p_{\boldsymbol{k}}^{h}$ annak az eseménynek a valószínúsége, hogy $\mathbb{Z}^{d}$-ben a $(0, \ldots, 0, h)$ pontból induló véletlen séta a $\left(k_{1}, \ldots, k_{d-1}, 0\right)$ pontban lép elöször az $x_{d}=0$ hipersíkra; $\mathcal{V}_{\boldsymbol{k}}^{h}$ pedig legyen azon $\mathbb{Z}^{d}$-beli $(0, \ldots, 0, h) \rightsquigarrow\left(k_{1}, \ldots, k_{d-1}, 0\right)$ véges séták halmaza, melyek a végpontjukkal lépnek először az $x_{d}=0$ hipersíkra (tehát a végpontot leszámítva a séta minden pontja az $x_{d}=0$ hipersík „felett” marad). Annak a valószínüsége, hogy az $A \in \mathbb{Z}^{d}$ pontból induló véletlen séta a $B \in \mathbb{Z}^{d-1} \times\{0\}$ pontban lép először az $x_{d}=0$ hipersíkra, szimmetriai okokból nyilvánvalóan megegyezik annak a valószínûségével, hogy az $A+\boldsymbol{v}$ pontból indított véletlen séta a $B+\boldsymbol{v}$ pontban lép elöször az $x$-tengelyre, ahol $\boldsymbol{v} \in \mathbb{Z}^{d-1} \times\{0\}$ egy tetszóleges, az $x_{d}=0$ hipersíkkal párhuzamos eltolásvektor. Így az egyszerúbb jelölésrendszer kedvéért most csak $(0, \ldots, 0, h)$ alakú pontokból induló véletlen sétákkal foglalkozunk; a más kezdőpontból indított véletlen séták $x_{d}=0$ hipersíkra vonatkozó „találati eloszlásának” vizsgálatakor automatikusan eltoljuk a „problémát” (átkoordinátázunk) a fenti értelemben úgy, hogy a kezdôpont az $x_{d}$-tengelyre kerüljön.

A következố eredmény a 3.1. Tételt általánosítja:

3.10. Tétel. $A \mathbb{Z}^{d-1} \ni \boldsymbol{k} \mapsto p_{\boldsymbol{k}}^{1}$ függvény szubharmonikus minden $\boldsymbol{k} \neq \mathbf{0}$ pontban.

Bizonyítás. Ugyanazt az utat követjük, mint a 3.1. Tétel bizonyításában. Elsô lépésük szerint osztályozva a $(0, \ldots, 0,1)$ pontból induló véletlen sétákat, világos, hogy $\boldsymbol{k} \neq \mathbf{0}$ esetén

$$
p_{\boldsymbol{k}}^{1}=\frac{1}{2 d}\left(\sum_{\boldsymbol{j} \in N(\boldsymbol{k})} p_{\boldsymbol{j}}^{1}+p_{\boldsymbol{k}}^{2}\right) .
$$

A bizonyítandó

$$
p_{\boldsymbol{k}}^{1} \leq \frac{1}{2(d-1)} \sum_{\boldsymbol{j} \in N(\boldsymbol{k})} p_{\boldsymbol{j}}^{1}
$$

egyenlőtlenség (3.20) behelyettesítése és rendezés után a

$$
(d-1) p_{\boldsymbol{k}}^{2} \leq \sum_{\boldsymbol{j} \in N(\boldsymbol{k})} p_{\boldsymbol{j}}^{1}
$$

alakot ölti (ha $\boldsymbol{k} \neq \mathbf{0}$ ). Azt mutatjuk meg, hogy $i=1, \ldots, d-1$ esetén

$$
p_{\boldsymbol{k}}^{2} \leq p_{\boldsymbol{k}-\boldsymbol{e}_{\boldsymbol{i}}}^{1}+p_{\boldsymbol{k}+\boldsymbol{e}_{\boldsymbol{i}}}^{1}
$$

teljesül (minden $\boldsymbol{k}$-ra); és így a $d-1$ egyenlőtlenség összegzésével adódik (3.21). Figyelembe véve, hogy

$$
p_{\boldsymbol{k}}^{h}=\sum_{V \in \mathcal{V}_{\boldsymbol{k}}^{h}}\left(\frac{1}{2 d}\right)^{|V|}
$$


elegendő egy hossztartó $\mathcal{V}_{\boldsymbol{k}}^{2} \rightarrow \mathcal{V}_{\boldsymbol{k}-\boldsymbol{e}_{\boldsymbol{i}}}^{1} \cup \mathcal{V}_{\boldsymbol{k}+\boldsymbol{e}_{\boldsymbol{i}}}^{1}$ injektív leképezést megadnunk (3.22) bizonyításaként.

Legyen $\boldsymbol{k}=\left(k_{1}, \ldots, k_{d-1}\right)$. A $\mathcal{V}_{\boldsymbol{k}}^{h}$-beli sétákat a következóképpen jellemezhetjük. Ahhoz, hogy a $(0, \ldots, 0, h)$ pontból indított séta végpontja $\left(k_{1}, \ldots, k_{d-1}, 0\right)$ legyen, a $\pm \boldsymbol{e}_{\boldsymbol{i}}$ lépések összege nyilván $k_{i} \boldsymbol{e}_{\boldsymbol{i}}$ kell legyen minden $1 \leq i \leq d-1$ irányra, és $-h \boldsymbol{e}_{\boldsymbol{d}}$ kell legyen az $i=d$,függóleges" irányra; ezekból a $+\boldsymbol{e}_{\boldsymbol{i}}$ és $-\boldsymbol{e}_{\boldsymbol{i}}$ lépések számának különbségére vonatkozó feltételeket kapunk minden $i$-re. Ezen túl csak a függóleges lépések sorrendjére van megkötés: $\operatorname{Egy} \mathcal{V}_{\boldsymbol{k}}^{h}$-beli séta utolsó lépése mindig $-\boldsymbol{e}_{\boldsymbol{d}}$,lefelé" lépés, illetve a $\pm \boldsymbol{e}_{\boldsymbol{d}}$ lépések sorozata olyan 1-dimenziós sétát határoz meg, mely a $h$ „magasságról” oly módon jut el a 0 magasságra, hogy a végpont elótt mindig pozitív magasságon tartózkodik. (Itt jegyezzük meg, hogy jelölésünk kissé pontatlan. Míg például a (3.22) formulában $\boldsymbol{e}_{\boldsymbol{i}}$ formálisan egy $(\boldsymbol{d}-1)$-dimenziós vektor, az imént $d$-dimenziós vektort értettünk alatta. Ezért $\mathbb{Z}^{d-1}$-re általában $\mathbb{Z}^{d-1} \times\{0\}$-ként tekintünk, $\mathbb{Z}^{d}$-be ágyazva.)

Megadunk egy alkalmas $\phi: \mathcal{V}_{\boldsymbol{k}}^{2} \rightarrow \mathcal{V}_{\boldsymbol{k}-\boldsymbol{e}_{\boldsymbol{i}}}^{1} \cup \mathcal{V}_{\boldsymbol{k}+\boldsymbol{e}_{\boldsymbol{i}}}^{1}$ injekciót, ahol $1 \leq i \leq d-1$ rögzített. Legyen $V \in \mathcal{V}_{\boldsymbol{k}}^{2}$ tetszóleges. A $d$-dimenziós $\boldsymbol{e}_{\boldsymbol{d}},-\boldsymbol{e}_{\boldsymbol{d}},-\boldsymbol{e}_{\boldsymbol{i}}$ és $\boldsymbol{e}_{\boldsymbol{i}}$ lépésekre rendre 2-dimenziós felfelé, lefelé, balra és jobbra lépésként tekintve, $V$ ezen lépései egy 2-dimenziós $\mathcal{W}_{k_{i}}^{(0,2)}$-beli $V^{*}$ sétát alkotnak. A 3.2. Lemma szerint létezik hossztartó $\psi: \mathcal{W}_{k_{i}}^{(0,2)} \rightarrow \mathcal{W}_{k_{i}-1}^{(0,1)} \cup \mathcal{W}_{k_{i}+1}^{(0,1)}$ injekció (a képként kapott sétákat az $y$ tengelyrôl indítva). Ennek felhasználásával $V$ képe legyen az a $\mathbb{Z}^{d}$-beli $\phi(V)$ séta, amelyet úgy kapunk, hogy $V$-ben $V^{*}$ lépéseit lecseréljük $\psi\left(V^{*}\right)$ lépéseire (pontosabban a 2-dimenziós lépéseknek megfeleltetett $d$-dimenziós lépésekre), természetesen a $\psi\left(V^{*}\right)$-beli sorrend megốrzésével, $V$ többi lépését változatlanul hagyva. Ez értelmes definíció $\psi$ hossztartása miatt, és nyilván $|\phi(V)|=|V|$. A $\mathcal{V}_{\boldsymbol{k}}^{h}$-beli séták fenti jellemzése alapján azonnal adódik, hogy $\phi(V) \in \mathcal{V}_{\boldsymbol{k}-\boldsymbol{e}_{\boldsymbol{i}}}^{1} \cup \mathcal{V}_{\boldsymbol{k}+\boldsymbol{e}_{\boldsymbol{i}}}^{1}$. Mivel $\phi$ injektivitása $\psi$ injektivitásából nyilvánvaló, az imént definiált $\phi$ leképezés rendelkezik a kívánt tulajdonságokkal.

Az előző tétel bizonyításának analógiájára kapjuk a 3.3. Tétel általánosítását:

3.11. Tétel. Tetszóleges rögzített $h \geq 2$ esetén $a \mathbb{Z}^{d-1} \ni \boldsymbol{k} \mapsto p_{\boldsymbol{k}}^{h}$ függvény szubharmonikus $a[h-1, \infty)^{d-1} \cap \mathbb{Z}^{d-1}$ halmaz pontjaiban.

Bizonyítás. (Vázlat.) Tekintsünk egy tetszóleges rögzített $\boldsymbol{k}=\left(k_{1}, \ldots, k_{d-1}\right) \in \mathbb{Z}^{d}$ pontot, melynek koordinátáira $k_{i} \geq h-1$ teljesül. Az előző tétel gondolatmenetét megismételve $\left(p_{\boldsymbol{m}^{-}}^{1}\right.$ et mindig $p_{\boldsymbol{m}^{-}}^{h}$-re, illetve $p_{\boldsymbol{m}}^{2}$-et mindig a $p_{m}^{h-1}+p_{m}^{h+1}$ összegre cserélve) arra jutunk, hogy elegendô azt igazolni, hogy minden $1 \leq i \leq d-1$ irányra létezik hossztartó $\phi_{i}: \mathcal{V}_{\boldsymbol{k}}^{h-1} \cup \mathcal{V}_{\boldsymbol{k}}^{h+1} \rightarrow \mathcal{V}_{\boldsymbol{k}-\boldsymbol{e}_{\boldsymbol{i}}}^{h} \cup \mathcal{V}_{\boldsymbol{k}+\boldsymbol{e}_{\boldsymbol{i}}}^{h}$ injekció. Adott $i$-re az elốốekhez hasonlóan konstruálhatunk alkalmas $\phi_{i}$-t: Egy $V \in \mathcal{V}_{\boldsymbol{k}}^{h-1} \cup \mathcal{V}_{\boldsymbol{k}}^{h+1}$ séta képe legyen az a séta, amelyet $V$-ból kapunk oly módon, hogy a $\pm \boldsymbol{e}_{\boldsymbol{i}}$ és $\pm \boldsymbol{e}_{\boldsymbol{d}}$ lépései által alkotott $\mathcal{W}_{k_{i}}^{(0, h-1)} \cup \mathcal{W}_{k_{i}}^{(0, h+1)}$-beli sétát átalakítjuk $\mathcal{W}_{k_{i}-1}^{(0, h)} \cup \mathcal{W}_{k_{i}+1}^{(0, h)}$-beli sétává a 3.4. Lemma szerint létezó hossztartó, injektív leképezéssel. (A lemmát alkalmazhatjuk, mert $k_{i} \geq h-1$.) Könnyen ellenőrizhető, hogy a kapott $\phi_{i}$ leképezés megfelelö lesz. 


\section{Összefoglalás}

A dolgozat két fố részból áll. A 2. fejezetben Shapiro páros indexú Catalanszámokra vonatkozó konvolúciós formulájával foglalkozunk [13; 123. o.], mely szerint

$$
\sum_{k=0}^{n} C_{2 k} C_{2 n-2 k}=4^{n} C_{n}
$$

ahol $C_{n}$ az $n$-edik Catalan-számot jelöli, vagyis $C_{n}=\frac{1}{n+1}\left(\begin{array}{c}2 n \\ n\end{array}\right)$. Ez az elegáns azonosság Stanley Bijective Proof Problems gyújteményében megoldatlanként szerepel [29; 194. probléma]. Bár a generátorfüggvény-módszer egy kézenfekvố bizonyítást szolgáltat, meglehetősen nehéz feladat kombinatorikus érveléssel igazolni a formulát. (Megjegyezzük, hogy Andrews [1] megfogalmazta az azonosság egy q-analóg változatát, melyre kombinatorikus bizonyítást is adott.)

A 2.2. alfejezetben ismertetünk egy egyszerú kombinatorikus bizonyítást, mely speciális utak összeszámlálásán alapul. A kombinatorikus interpretáció kulcsa egy régi Monthly-problémaként kitúzött észrevétel [25,3,19], mely szerint $C_{2 n}$ az origóból a $(4 n, 0)$ pontba menô páros-metszô utakat számolja meg. (A páros-metszô utak olyan $(1,1)$ és $(1,-1)$ lépésekból álló utak $\mathbb{Z}^{2}-n$, amelyek soha nem metszik az $x$-tengelyt $(4 k+2,0)$ alakú pontban, ahol $k \in \mathbb{Z}$.) Ez a tény bizonyítható bijekció megadásával a szóban forgó utak halmaza és a $4 n$ hosszú Dyck-utak halmaza között, lásd 2.4. Lemma. Ebból közvetlen következményként adódik, hogy a Shapiro-azonosság bal oldala, a $\sum_{k=0}^{n} C_{2 k} C_{2 n-2 k}$ összeg, az origóból a $(4 n+1,1)$ pontba menő páros-metsző utakat számolja meg (2.5. Következmény). Kombinatorikus bizonyításunk befejező lépéseként megmutatjuk a 2.7. Lemmában, hogy az origóból a $(4 n+1,1)$ pontba menô páros-metszô utak száma egyben a jobb oldal is, $4^{n} C_{n}$. Ezen a ponton indukcióval érvelünk, és felhasználjuk, hogy a Shapiro-formula mindkét oldalát $(n+1)$-gyel szorozva, és a $B_{n}=\left(\begin{array}{c}2 n \\ n\end{array}\right)$ jelöléssel élve a

$$
\sum_{k=0}^{n} C_{2 k} B_{2 n-2 k}=4^{n} B_{n}
$$

ekvivalens alakot kapjuk, amely értelmezhetô egy eddigiekhez hasonló útleszámlálási problémára adott válaszként is.

A 2.3. alfejezetben az utolsó lépés induktív érvelését is bijektívvé tesszük, és így egy teljes egészében bijektív bizonyításhoz jutunk, mellyel megoldjuk Stanley feladatát. Ez a 2. fejezet fő eredménye, mely Hajnal Péterrel közös munka gyümölcse. Ebben az alfejezetben tehát egy összetett bijekciót konstruálunk a $(0,0) \rightsquigarrow(4 n+1,1)$ páros-metszố utak halmaza és egy alkalmas $4^{n} C_{n}$ elemú halmaz 
között. (Ez utóbbi halmaznak a $2 n$ hosszú 4-címkézett Dyck-utak halmazát választjuk, amely formális megfogalmazásban nem más, mint a $2 n$ hosszú Dyck-utak halmazának és az $\{1,2,3,4\}^{n}$ halmaznak a direkt szorzata.) Az alfejezetet konstrukciónk néhány következményével zárjuk (2.11. és 2.12. Következmény). Ezek egyike a Catalan-számok egy új interpretációja, mely szerint $n \geq 1$ esetén $C_{n}$ megszámolja azon $(1, \pm 1)$ és $(1, \pm 2)$ lépésekból álló $(0,0) \rightsquigarrow(n, 1)$ utakat, amelyek a kezdôpont után soha nem lépnek az $x$-tengelyre.

A 2.4. alfejezetben módszerünk néhány alkalmazását mutatjuk be. A legfontosabb ezek közül a középsố binomiális együtthatók alternáló konvolúciós formulájának új elemi bizonyítása, a 2.16. Tétel. (A formulát Spivey [28] bizonyította elôször kombinatorikusan a közelmúltban, más eszközökkel, véletlen színezett permutációk segítésével.) Végül a fejezet zárásaként két sejtést fogalmazunk meg számítógépes vizsgálatok alapján a 2.5. alfejezetben.

A 3. fejezetben szimmetrikus véletlen séták egy konvexitási tulajdonságával foglalkozunk. A fejezet Totik Vilmossal és Szalai Attilával közös munkákon alapul. Az alapprobléma egy harmonikus mértékekkel kapcsolatos friss eredmény [2] új bizonyításának fólemmája [18]: Ha $p_{k}$ jelöli annak a valószínûségét, hogy a $(0,1)$ pontból induló $\mathbb{Z}^{2}$-beli (szimmetrikus) véletlen séta a $(k, 0)$ pontban lép elôször az $x$-tengelyre $(k \in \mathbb{Z})$, akkor a $\left(p_{k}\right)_{k=0}^{\infty}$ sorozat konvex, vagyis $p_{k} \leq \frac{1}{2}\left(p_{k-1}+p_{k+1}\right)$ teljesül $k \geq 1$ esetén. A $p_{k}$ valószínúséghez hozzájáruló sétákat az elsó lépésük, illetve az elsố $x$-tengelymetszetig tartó szakaszuk szerint osztályozva, nem nehéz látni, hogy az állítás igazolásához elegendô megadni egy hossztartó injektív leképezést a $\mathcal{W}_{k}^{(0,2)}$ halmazból a $\mathcal{W}_{k}^{(1,1)} \cup \mathcal{W}_{k}^{(-1,1)}$ halmazba, ahol $\mathcal{W}_{k_{2}}^{\left(k_{1}, h\right)}$ azon $\mathbb{Z}^{2}$-beli véges $\left(k_{1}, h\right) \rightsquigarrow\left(k_{2}, 0\right)$ séták halmazát jelöli, melyek a végpontot leszámítva soha nem lépnek az $x$-tengelyre.

A 3.2. alfejezetben ismertetünk egy alkalmas injekciót, és ezzel egy számolásmentes elemi bizonyítást adunk az állításra. (A 3.1. és 3.3. alfejezetekben vázolunk más megközelítéseket is.)

A 3.3. alfejezetben más kezdőpontú véletlen sétákat is megvizsgálunk. Az eddigiek általánosításaként megmutatjuk, hogy ha $p_{k}^{h}$ jelöli annak a valószínúségét, hogy a $(0, h)$ pontból induló véletlen séta a $(k, 0)$ pontban lép elóször az $x$-tengelyre, akkor a $\left(p_{k}^{h}\right)_{k=h-2}^{\infty}$ sorozat konvex (rögzített $h \geq 2$ esetén). Bizonyításunkban a $h=1$ esethez hasonlóan járunk el, azonban további ötletekre is szükség van. Ezután a folytonos eset alapján célként fogalmazzuk meg eredményünk lehetséges élesítési irányait, majd tárgyaljunk elemi módszerünk korlátait is. Eközben a bijektív kombinatorika szemszögéból érdekes megoldatlan összefüggéseket találunk (3.6. Tétel és 3.9. Lemma).

Végezetül a 3.4. alfejezetben a probléma magasabb dimenziós megfelelójét tekintjük. A $d$-dimenziós diszkrét véletlen séta $x_{d}=0$ hipersíkkal vett elsô metszéspontjának eloszlását (diszkrét) szubharmonikusság szempontjából vizsgálva a síkbeli esethez hasonló eredményekhez jutunk tetszóleges $d \geq 2$ dimenzióra (ld. 3.10. és 3.11. Tétel). Ezeket a tételeket a $d=2$ alapesetre történó visszavezetéssel igazoljuk. 
A disszertáció a szerzố alábbi négy publikációján alapul:

- G. V. NAGY: A combinatorial proof of Shapiro's Catalan convolution, Adv. in Appl. Math. 49 (2012), 391-396.

- P. Hajnal \& G. V. NAGY: A bijective proof of Shapiro's Catalan convolution, Electron. J. Combin. 21 (2014), Issue 2, Paper \#P2.42, 1-10.

- G. V. Nagy \& V. Totik: A convexity property of discrete random walks, benyújtva (2014).

- G. V. Nagy \& A. Szalai: On the convexity of a hitting distribution for discrete random walks, Acta Sci. Math. (Szeged), elfogadva (2014). 


\section{Summary}

This thesis consists of two main parts. In Chapter 2, we deal with Shapiro's convolution formula involving Catalan numbers of even index [13; p. 123], that is,

$$
\sum_{k=0}^{n} C_{2 k} C_{2 n-2 k}=4^{n} C_{n}
$$

where $C_{n}$ denotes the $n$th Catalan number, i.e. $C_{n}=\frac{1}{n+1}\left(\begin{array}{c}2 n \\ n\end{array}\right)$. This elegant identity is listed in Stanley's Bijective Proof Problems as unsolved [29; Problem 194]. It is straightforward to prove it using generating functions, but it is quite difficult to find a combinatorial proof. (We note that Andrews [1] formulated a $q$-analog of Shapiro's identity, and he managed to prove it combinatorially.)

A simple combinatorial proof is presented in Section 2.2, based on a pathcounting argument. The following observation, that has been posed as a Monthly problem $[25,3,19]$, is the key to the combinatorial interpretation of the formula: $C_{2 n}$ counts the number of even-zeroed paths from the origin to the point $(4 n, 0)$, where an even-zeroed path is defined as a path on $\mathbb{Z}^{2}$ with steps $(1,1)$ and $(1,-1)$ such that it never hits the $x$-axis at a point of the form $(4 k+2,0)$ for $k \in \mathbb{Z}$. This can be proved by giving a bijection between the set of these paths and the set of Dyck paths of length $4 n$, see Lemma 2.4. As a direct corollary, we obtain that the left-hand side of Shapiro's identity, the sum $\sum_{k=0}^{n} C_{2 k} C_{2 n-2 k}$, counts the number of even-zeroed paths from the origin to $(4 n+1,1)$, see Corollary 2.5. As the final step of the combinatorial proof, we show in Lemma 2.7 that $4^{n} C_{n}$, the right-hand side, also counts the number of even-zeroed paths from the origin to $(4 n+1,1)$. This is done by an inductive argument based on the fact that, after multiplying both sides by $(n+1)$, Shapiro's formula can be written in the form

$$
\sum_{k=0}^{n} C_{2 k} B_{2 n-2 k}=4^{n} B_{n}
$$

which can be interpreted as an answer to a path-counting problem analogous to the above. (Here we used the notation $B_{n}=\left(\begin{array}{c}2 n \\ n\end{array}\right)$.)

In Section 2.3, we replace the inductive argument in the final step with a bijective one, thus we obtain an entirely bijective proof, a solution to Stanley's problem. This is the main result of Chapter 2, which is joint work with Péter Hajnal. So in this section we construct a sophisticated bijection between the set of $(0,0) \rightsquigarrow(4 n+1,1)$ even-zeroed paths and an appropriate set with $4^{n} C_{n}$ elements. (The latter set is chosen to be the set of 4 -labeled Dyck paths of length $2 n$, i.e. the 
Cartesian product of the set of Dyck paths of length $2 n$ and the set $\{1,2,3,4\}^{n}$.) We end the section with some corollaries of our construction, see Corollaries 2.11 and 2.12. One of them is a new interpretation of Catalan numbers: We obtained that, for $n \geq 1, C_{n}$ counts the number of such $(0,0) \rightsquigarrow(n, 1)$ paths in which every step is either $(1, \pm 1)$ or $(1, \pm 2)$ and that never hit the $x$-axis after the starting point.

We present some applications of the main lemma in Section 2.4. The most important of these is Theorem 2.16, a simple direct combinatorial proof of the alternating convolution formula of central binomial coefficients. (We note that this formula has been first proved combinatorially by Spivey recently. He uses a different approach, his proof is based on random colored permutations.) Finally, we end the chapter by posing two conjectures, based on computational experience, in Section 2.5 .

In Chapter 3, we deal with a convexity property of symmetric random walks. The chapter is based on joint works with Vilmos Totik and Attila Szalai. The basic result here is the main lemma of a new proof [18] of a recent result [2] about harmonic measures: If $p_{k}$ denotes the probability that a (symmetric) random walk on the integer lattice $\mathbb{Z}^{2}$ starting from the point $(0,1)$ first hits the $x$-axis at $(k, 0)$, then the sequence $\left(p_{k}\right)_{k=0}^{\infty}$ is convex, that is, $p_{k} \leq \frac{1}{2}\left(p_{k-1}+p_{k+1}\right)$ holds for all $k \geq 1$. By grouping the walks corresponding to $p_{k}$ by their first step and by their initial part until the first intersection with the $x$-axis, it is not hard to see that in order to prove the statement, it is enough to give a length-preserving injection from the set $\mathcal{W}_{k}^{(0,2)}$ into the set $\mathcal{W}_{k}^{(1,1)} \cup \mathcal{W}_{k}^{(-1,1)}$, where $\mathcal{W}_{k_{2}}^{\left(k_{1}, h\right)}$ denotes the set of such finite $\left(k_{1}, h\right) \rightsquigarrow\left(k_{2}, 0\right)$ walks on $\mathbb{Z}^{2}$ that never hit the $x$-axis before their last step.

We present a suitable injection in Section 3.2, thus giving elementary proof of the statement, without involving any calculations. (We also sketch some other approaches in Sections 3.1 and 3.3.)

In Section 3.3, we consider random walks with arbitrary starting point. As a generalization of the above, we show that if $p_{k}^{h}$ denotes the probability that a random walk starting from the point $(0, h)$ first hits the $x$-axis at $(k, 0)$, then the sequence $\left(p_{k}^{h}\right)_{k=h-2}^{\infty}$ is convex (for a fixed $h \geq 2$ ). The proof is analogous to the case $h=1$, but additional ideas are involved as well. Next, we discuss some possible directions of future improvement, suggested by the continuous case, then we examine the limit of our elementary method. As a corollary, we obtain two interesting facts (Theorem 3.6 and Lemma 3.9) for which we do not know any combinatorial proof.

Finally, we consider the higher dimensional analogue of the problem in Section 3.4. We investigate the (discrete) subharmonicity of the hitting distribution of the $x_{d}=0$ hyperplane for discrete $d$-dimensional random walks $(d \geq 2)$. The presented results, Theorems 3.10 and 3.11, are analogous to the 2-dimensional ones, moreover, they can be deduced from the base case $d=2$.

The dissertation is based on the following four papers of the author: 
- G. V. NAGY: A combinatorial proof of Shapiro's Catalan convolution, Adv. in Appl. Math. 49 (2012), 391-396.

- P. Hajnal \& G. V. Nagy: A bijective proof of Shapiro's Catalan convolution, Electron. J. Combin. 21 (2014), Issue 2, Paper \#P2.42, 1-10.

- G. V. NAgy \& V. Totik: A convexity property of discrete random walks, submitted (2014).

- G. V. Nagy \& A. Szalai: On the convexity of a hitting distribution for discrete random walks, Acta Sci. Math. (Szeged), accepted (2014). 


\section{Köszönetnyilvánítás}

Mindenekelőtt szeretnék köszönetet mondani témavezetőmnek, Hajnal Péternek, kinek szakmai segítségére és támogatására hallgató korom óta számíthatok. Észrevételeire, problémafelvetéseire és javaslataira e disszertáció megírása során is támaszkodhattam. Az ô élvezetes egyetemi előadásai és szemináriumai ismertették meg velem a kombinatorika szépségét; előadásmódjával és személyiségével nemcsak matematikai gondolkodásomat formálta.

Köszönettel tartozom további társszerzôimnek is. Nagymértékben hozzájárult a dolgozat megszületéséhez, hogy Totik Vilmos professzor bevont a 3. fejezetben ismertetett probléma megoldásába, illetve hogy közös cikkünk elkészítésekor a hozzám tartozó részek gondos átolvasása után hasznos tanácsokkal látott el. Szalai Attilával pedig jó hangulatú közös munka keretében sikerült további eredményeket elérni a témakörben.

Szeretném megköszönni a Bolyai Intézetnek, hogy biztosította a disszertáció elkészítéséhez szükséges körülményeket - nemcsak az intézményi feltételeket, hanem a magas szakmai színvonalat és kellemes munkahelyi légkört is ideértve. Továbbá köszönöm a Jedlik Ányos Doktorjelölti Ösztöndíj anyagi támogatását.

Köszönet illeti édesapámat, egyben általános iskolai matematika tanáromat, valamint középiskolai tanáraimat, Biczóné Lengyel Beátát és Terlaky Editet, akiktól a matematika alapjait tanultam.

Végül, de nem utolsósorban, hálás vagyok családomnak és barátaimnak a sok támogatásért, valamint a nehezebb idôszakokban nyújtott biztatásért. 


\section{Jelölések, fogalmak}

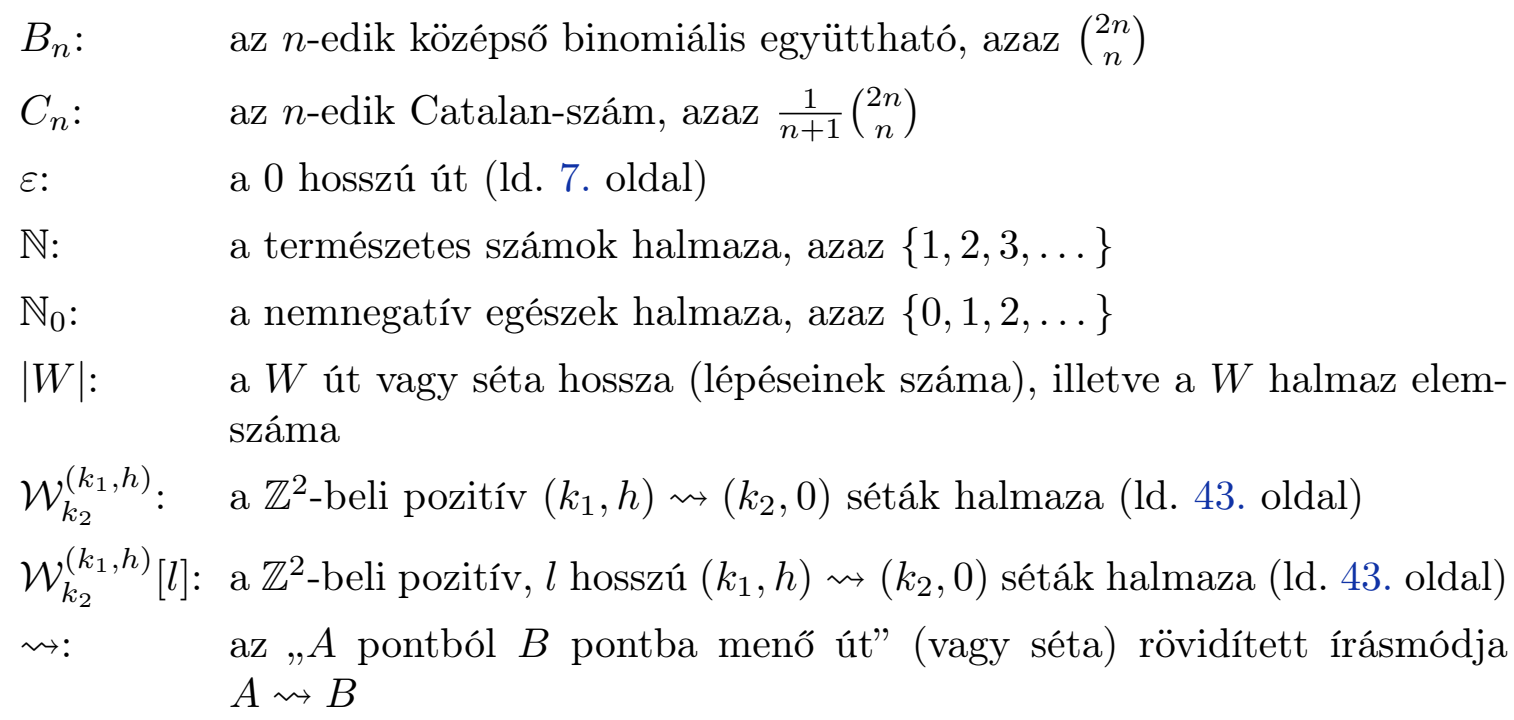

Az alábbi definíciókban az utakat az origóból indítjuk. (A pozitív sétákat nem.)

4-címkézett Dyck-út: Olyan Dyck-út, amelynek minden párosadik lépése meg van címkézve a $\{0,1,2,3\}$ halmazból, a páratlanadik lépések pedig címkézetlenek (18. oldal).

Dyck-út: Olyan út, amely az $x$-tengelyen végződik, de soha nem megy az $x$-tengely alá (8. oldal).

jelölt Dyck-út: Olyan Dyck-út, amelyben minden párosadik lépés vagy jelölt vagy jelöletlen, a páratlanadik lépések pedig jelöletlenek (19. oldal).

kiegyensúlyozott út: Olyan út, amely az $x$-tengelyen végződik, azaz ugyanannyi felfelé lépést tartalmaz, mint lefelé lépést (8. oldal).

nemnegatív út: Olyan út, amely soha nem megy az $x$-tengely alá (8. oldal).

páros-metszô út: Olyan út, amely az $x$-tengelyt csak 4-gyel osztható (abszcisszájú) pontokban metszi (9. oldal).

pozitív séta: Olyan $\mathbb{Z}^{2}$-beli séta, amely az utolsó lépését megelôzően mindig szigorúan az $x$-tengely fölött tartózkodik; a végpont lehet az $x$-tengelyen (43. oldal).

seholsem-zéró út: Olyan út, amely soha sem lép az $x$-tengelyre, a kezdópontot leszámítva (8. oldal).

tömörített út: Olyan általánosított út, amelyben minden párosadik lépés vagy hosszú lépés, vagy 3-címkézett rövid lépés, és minden páratlanadik lépés címkézetlen rövid lépés (17. oldal). 


\section{Irodalomjegyzék}

[1] G. E. Andrews: On Shapiro's Catalan convolution, Adv. in Appl. Math. 46 (2011), 15-24.

[2] D. Benko, P. Dragnev \& V. Totik: Convexity of harmonic densities, Rev. Mat. Iberoam. 28 (2012), 947-960.

[3] D. M. Bloom \& L. W. Shapiro: Random Walks and Catalan Numbers, Amer. Math. Monthly 92 (1985), 430.

[4] W. Breckenridge, H. Gastineau-Hills, A. Nelson, P. Bos, G. CalVErt \& K. Wehrhahn: Lattice paths and Catalan numbers, Bull. Inst. Combin. Appl. 1 (1991), 41-55.

[5] J. L. Doob: Classical potential theory and its probabilistic counterpart, Grundlehren der Mathematischen Wissenschaften, Vol. 262, Springer-Verlag, New York, 1984.

[6] Ö. EĞECIOĞLU \& A. KING: Random walks and Catalan factorization, Congr. Numer. 138 (1999), 129-140.

[7] J. B. Garnett \& D. E. Marshall: Harmonic measure, New Mathematical Monographs, Vol. 2, Cambridge University Press, Cambridge, 2005.

[8] A. M. Garsia \& S. C. Milne: Method for constructing bijections for classical partition identities, Proc. Nat. Acad. Sci. U.S.A. 78 (1981), 2026-2028.

[9] A. M. Garsia \& S. C. Milne: A Rogers-Ramanujan bijection, J. Combin. Theory Ser. A 31 (1981), 289-339.

[10] R. K. Guy, C. Krattenthaler \& B. E. Sagan: Lattice paths, reflections, \& dimension-changing bijections, Ars Combin. 34 (1992), 3-15.

[11] P. Hajnal: Összeszámlálási problémák, Polygon, Szeged, 1997.

[12] P. Hajnal \& G. V. Nagy: A bijective proof of Shapiro's Catalan convolution, Electron. J. Combin. 21 (2014), Issue 2, Paper \#P2.42, 1-10.

[13] T. Koshy: Catalan numbers with applications, Oxford University Press, Oxford, 2009.

[14] G. F. LAwleR \& V. Limic: Random walk: a modern introduction, Cambridge Studies in Advanced Mathematics, Vol. 123, Cambridge University Press, Cambridge, 2010.

[15] P. Mörters \& Y. Peres: Brownian motion, Cambridge Series in Statistical and Probabilistic Mathematics, Cambridge University Press, Cambridge, 2010. 
[16] G. V. Nagy: A combinatorial proof of Shapiro's Catalan convolution, Adv. in Appl. Math. 49 (2012), 391-396.

[17] G. V. Nagy \& A. Szalai: On the convexity of a hitting distribution for discrete random walks, Acta Sci. Math. (Szeged), elfogadva (2014).

[18] G. V. NAgy \& V. Totik: A convexity property of discrete random walks, benyújtva (2014).

[19] W. Nichols: A path bijection, Amer. Math. Monthly 94 (1987), 465-466.

[20] I. PAK: Partition bijections, a survey, 2002. http://www.math.ucla.edu/ pak/papers/psurvey.pdf

[21] M. Petkovšek, H. S. Wilf \& D. Zeilberger: $A=B$, A K Peters, Ltd., Wellesley, MA, 1996.

[22] S. Ramanujan: Proof of certain identities in combinatory analysis, Proc. Cambridge Philos. Soc. 19 (1919), 214-216.

[23] M. Renault: Four proofs of the ballot theorem, Math. Mag. 80 (2007), 345352.

[24] L. J. Rogers: Second Memoir on the Expansion of certain Infinite Products, Proc. London Math. Soc. 25 (1894), 318-343.

[25] L. W. Shapiro: Problem E2903, Amer. Math. Monthly 88 (1981), 619.

[26] N. J. A. Sloane \& S. Plouffe: The encyclopedia of integer sequences, Academic Press, Inc., San Diego, CA, 1995.

[27] F. SpItzer: Principles of random walk, Second edition, Graduate Texts in Mathematics, Vol. 34, Springer-Verlag, New York-Heidelberg, 1976.

[28] M. Z. SpIVEY: Combinatorial interpretation of the alternating convolution of the central binomial coefficients, 2012. http://mikespivey.wordpress.com/2012/03/16/altconvcentralbinom/

[29] R. P. Stanley: Bijective proof problems, 2009. http://www-math.mit.edu/〜rstan/bij.pdf

[30] R. P. Stanley: Catalan addendum, 2013. http://www-math.mit.edu/〜rstan/ec/catadd.pdf

[31] R. P. Stanley: Enumerative combinatorics, Vol. 1, Second edition, Cambridge Studies in Advanced Mathematics, Vol. 49, Cambridge University Press, Cambridge, 2012.

[32] R. P. Stanley: Enumerative combinatorics, Vol. 2, Cambridge Studies in Advanced Mathematics, Vol. 62, Cambridge University Press, Cambridge, 1999.

[33] M. Sved: Counting and recounting: the aftermath, Math. Intell. 6 (1984), $44-45$. 
[34] H. S. WILf: Lectures on integer partitions, 2000. www. math. upenn. edu/ ${ }^{\text {wilf } / P I M S / P I M S L e c t u r e s ~ . p d f ~}$ 